\title{
BIODEGRADATION OF DISSOLVED HUMIC SUBSTANCES BY FUNGI
}

Sergio Collado ${ }^{a}$, Paula Oulego ${ }^{a}$, Octavio Suárez-Iglesias $^{a}$, Mario Díaz $^{a *}$

${ }^{a}$ Department of Chemical and Environmental Engineering. University of Oviedo.

C/ Julián Clavería s/n. E-33071 Oviedo, Spain. Tel.:34985103439; Fax: 34985103434

*mariodiaz@uniovi.es 


\section{Graphical abstract}

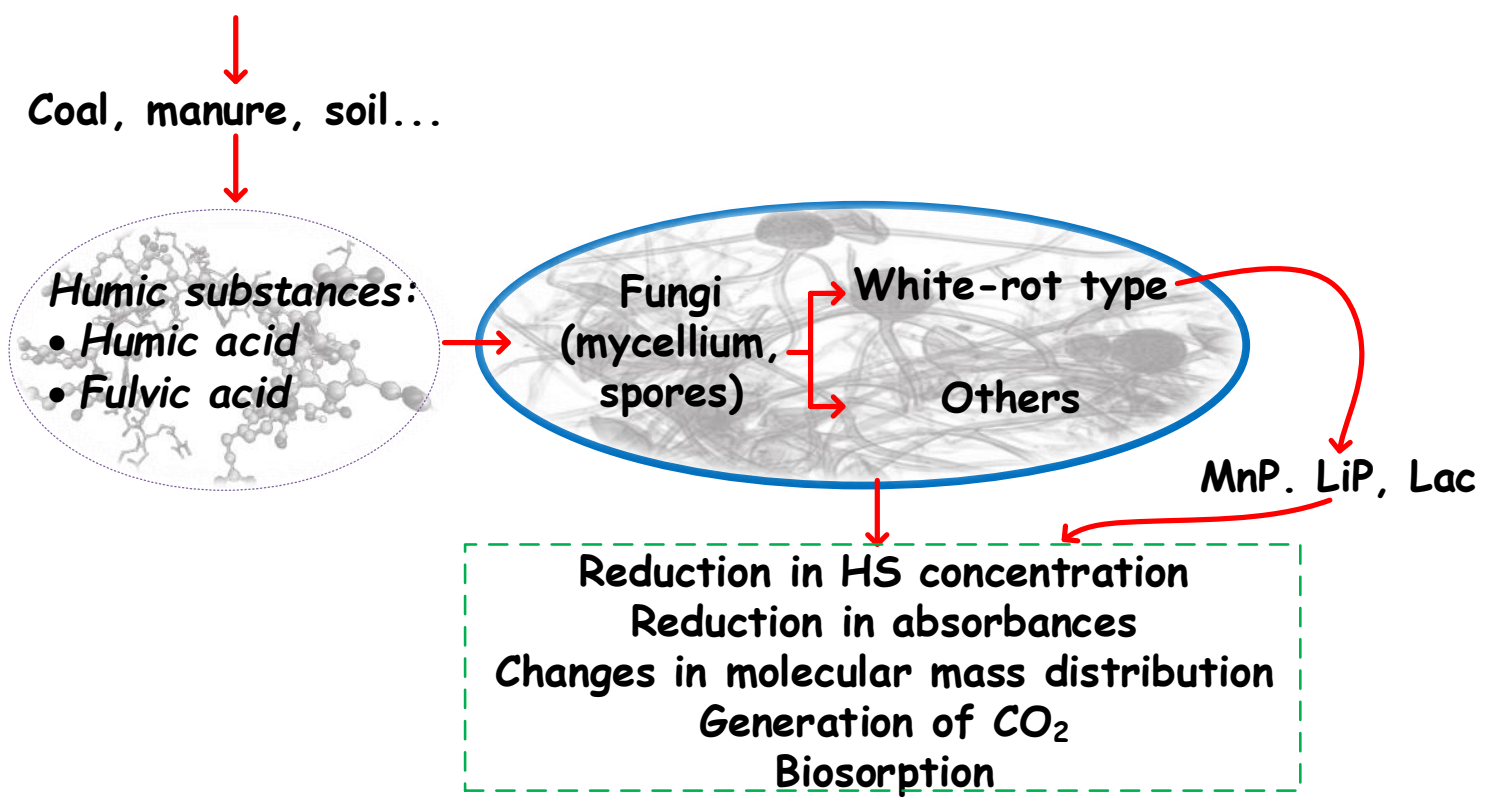

\section{Highlights}

Importance of humic substances interaction with fungi

Fungal biodegradation is a complex function of the experimental conditions.

Enzymatic activity individually does not always fully explain the biodegradation.

Humic substances can be removed by biosorption as well. 


\begin{abstract}
Humic and fulvic acids constitute humic substances, a complex mixture of many different acids containing carboxyl and phenolate groups, which are not only the principal soil fertility factors but also the main pollutants present in landfill leachates or natural organic matter in water. Due to their low bacterial biodegradability, fungal biodegradation processes are key for their removal. The present study compiles and comments all the available literature on decomposition of aqueous humic substances by fungi or by their extracellular enzymes alone, focusing on the influence of the reaction conditions. The biodegradation extent mainly depends on the characteristics and concentration of the humic compounds, the type of microorganisms selected, the inoculation mode, the $\mathrm{C}$ and $\mathrm{N}$ sources, the presence of certain chemicals in the medium, the availability of oxygen, the temperature and the $\mathrm{pH}$.
\end{abstract}

\title{
Keywords:
}

Humic substances, humic acid, fulvic acid, fungi, ligninolytic enzymes

\section{Introduction.}

When organic matter from coal, manure, compost, soil or water is extracted with alkali, the soluble fraction generated consists of humic substances (HS), whereas the insoluble one contains products called humin and non-humic matter (McDonald et al., 2004). The HS are the most widespread and ubiquitous natural nonliving organic materials in terrestrial and aquatic environments and they represent the major fraction of soil organic matter (Granit et al. 2007). Properties of soil like water holding capacity, sequestration of nutrients and its transport, biological activity are directly affected by humic substances. If HS is subjected to a subsequent acid extraction, the solubilized polymers 
are known as fulvic acids (FA), and those which remain in solid state correspond to humic acids (HA). Both recalcitrant acids are also the main components of natural organic matter in water (Bhatnagar and Sillanpää, 2017) and of old-landfill leachates (Gao et al., 2015), being occasionally used as model pollutants in laboratory tests for purifying drinking water (Kim and Dempsey, 2013) or for treating wastewater (Oulego et al., 2015, 2016). Nonetheless, since HA and FA contain lignin-like moieties such as anthraquinones, substituted benzoic acids and substituted cinnamic acids, they could also be employed as surrogates for wastewaters from textile, pulp and paper, olive mill and brewery industries, amongst others (Belcarz et al., 2005), which is another reason for their environmental importance.

In nature, humic substances are extremely resistant to biodegradation. It is now known that several microorganisms, mainly fungi, can decolorize and even completely mineralize humic acids under certain environmental conditions. Fungi are classified in four or five phyla, being those belonging to the Ascomycota and to the Basidiomycota the most frequent in the soil and employed for bioremediation (Sankaran et al., 2010; Tortella et al., 2005). Within both phyla, the wood-degrading type, and specially the white-, brown- and soft-rot fungi, deserve a special mention: they excrete extracellular enzymes that decompose complex nutrients into simpler substances that can be easily absorbed through the cell wall.

White rot and brown rot are mainly exerted by basidiomycetes, whereas soft rot is mainly performed by ascomycetes (Kües, 2015). Brown-rot fungi attack lignin by Fenton chemistry, turning it into a brown oxidized form and then, degrading it by means of the enzymes. White-rot fungi attack directly the lignin (or lignin-like) polymers through ligninolytic enzymes, mainly lignin peroxidase (LiP), manganese peroxidase 
(MnP) and laccase (Lac) (Yadav and Yadav, 2015). Soft-rot fungi only perform a partial enzymatic degradation of cell wall polysaccharides and slight alterations of lignin. Lac [EC 1.10.3.2] are copper-containing oxidases that utilize molecular oxygen as oxidant, whereas peroxidases are hemeproteins that catalyze the reduction of the hydrogen peroxide endogenously generated. The mechanism of LiP [EC 1.11.1.7] includes the oxidation of veratryl alcohol (an endogenously produced redox mediator) and the action of MnP [E.C.1.11.1.13] involves the oxidation of $\mathrm{Mn}(\mathrm{II})$ to $\mathrm{Mn}(\mathrm{III})$ prior to the oxidation of the targeted substrates (Ikehata et al., 2004). Other enzymes unable of breaking lignin, but implicated in the process, such as glycosal oxidase and superoxide dismutase (both related with the generation of $\mathrm{H}_{2} \mathrm{O}_{2}$ ), glucose oxidase, cellubiosequinone oxidoreductase, aryl alcohol oxidase (AAO), horseradish-like peroxidase (HRP), cytochrome P450 enzymes and tyrosinase (also known as monophenol monooxygenase, MMO) are produced by the fungi as well (Pointing, 2001).

In this study, all the literature published to the date about application of fungi and their enzymes to bioremediation of HS-containing water is compiled and discussed. Unlike the existing review of Grinhut et al. (2007), the present one is not a description of the performance of these microorganisms in natural environments, but an analysis of the effect of the experimental variables on the fungal biodegradation of HA or FA in aqueous media,. Additionally, this paper also addresses the combination of biosorption with biodegradation, since fungi can also remove some compounds by adsorption to the biomass (Zhou and Banks, 1993). 


\section{General remarks}

Precursor compounds of $H S$

The formation of humic substances is one of the least understood aspects of humus chemistry and one of the most intriguing. Preliminary understandings about how humic substances are formed is based on 4 published theories: lignin modification, quinone amino acid interaction, microbial synthesis of aromatics, and the Mallard reaction. Each theory describes complicated biotic and abiotic reactions in which a variety of organic compounds, such as phenolic compounds (eg. lignins), complex carbohydrates, and nitrogenous substances are resynthesized to form large complex polymers. The extreme variability in the molecular features of humic substances relates back to the precursor compounds and the environmental conditions under which the humic substances formed (Stevenson, 1994; Tan, 2014). Therefore, the parent material from which HS are formed is a variable taken into consideration.

In this regard, 41 references investigating fungal decomposition of HS, HA or FA in liquid media have been compiled. Table 1 presents them briefly. Regarding the origin of the HS employed, 16 of them are focused on compounds extracted from soil (Belcarz et al., 2005; Blondeau, 1989; Burges and Latter, 1960; Dehorter and Blondeau, 1992;

Dehorter et al., 1992; Gramss et al., 1999; Koukol et al., 2004; Mathur, 1969, 1970; Mathur and Paul, 1966, 1967; Mishra and Srivastava, 1986; Paul and Mathur, 1967; Řezáčová et al., 2006; Yanagi et al., 2002, 2003), 13 on HS or HA from coal (Fakoussa and Frost, 1999; Hofrichter and Fritsche, 1997a; Kabe et al., 2005; Ralph and Catcheside, 1994, 1998a, b, 1999; Ralph et al., 1996; Temp et al., 1999; Willmann and Fakoussa, 1997; Wondrack et al., 1989; Zahmatkesh et al., 2016; Ziegenhagen and Hofrichter, 1998), 3 on HA from compost (Grinhut et al., 2011a, b; Kluczek-Turpeinen 
et al., 2005) and 1 on HS, HA and FA from groundwater (Claus and Filip, 1998).

Besides, 3 works use semi-synthetic or synthetic HA (Haider and Martin, 1988;

Hofrichter et al., 1998; Wunderwald et al., 2000).

\section{TABLE 1}

There are also papers that utilize compounds from two origins: soil and coal (Kornillowicz-Kowalska et al., 2008; Zavarzina et al., 2004), soil and manure (Khandelwal and Gaur, 1980), soil and commercial (Petrovic et al., 1993) and litter and synthetic (Steffen et al., 2002). Of the 41 references, 1 deals with HA, HS and FA (Claus and Filip, 1998), 3 with HA and FA (Mathur, 1970; Petrovic et al., 1993; Řezáčová et al., 2006), 3 with HS (Gramss et al., 1999; Hofrichter and Fritsche, 1997a; Temp et al., 1999), 1 with FA (Mathur, 1969) and the remaining 33 with HA alone.

It has to be pointed out that the works of Hofrichter and Fritsche (1997a) and Temp et al. (1999) erroneously employed the term HA to designate HS, because the second acidic step was not performed, and that Belcarz et al. (2005) called HA to both true HA and to a mixture of HA and humin (therefore, this last mixture is not considered in this review).

We have not considered those publications that only studied degradation in solid media, such as those of Hurst et al. (1962), Hofrichter and Fritsche (1996, 1997b), Steffen et al. (2000), Elbeyli et al. (2006), Granit et al. (2007) and Šnajdr et al. (2010), nor the experiments in solid media of those articles working with liquids as well (Belcarz et al., 2005; Burges and Latter, 1960; Kluczek-Turpeinen et al., 2005; Kornillowicz-Kowalska et al., 2008; Řezáčová et al., 2006; Steffen et al., 2002; Zahmatkesh et al., 2016). 
The degradation of HS by fungi is mainly followed by ultraviolet-visible spectrophotometry. Most of the researchers measured absorbances at wavelengths between 275 and $665 \mathrm{~nm}$, and estimated decolorization or bleaching through the decrease in these absorbances. However, a few authors stated that some wavelengths are better than others for evaluating certain properties, although they do not agree regarding to specific values. For example, Řezáčová et al. (2006) associated absorbances at $280 \mathrm{~nm}$ with the phenolic content or the aromaticity of the compounds, and absorbances at $665 \mathrm{~nm}$ with the color, whereas Kabe et al. (2005) affirmed that color is better determined at $480 \mathrm{~nm}$ and depolymerization at $275 \mathrm{~nm}$. Belcarz et al. (2005) and Kornillowicz-Kowalska et al. (2008) used 400 - $450 \mathrm{~nm}$ for color and 500 $\mathrm{nm}$ for vanillic acid-like compounds (methoxyphenolic levels). Kluczek-Turpeinen et al. (2005) selected $450 \mathrm{~nm}$ for HA monitoring and $360 \mathrm{~nm}$ for FA monitoring without further explanations, despite the fact that the rest of literature indistinctly employed these wavelengths for both acids (Fakoussa and Frost, 1999; Hofrichter and Fritsche, 1997a; Řezáčová et al., 2006). Moreover, ratios of absorbances at two different wavelengths in the ultraviolet (Ralph and Catcheside, 1999) or visible ranges (Claus and Filip, 1998; Koukol et al., 2004; Mathur and Paul, 1967; Řezáčová et al., 2006; Zavarzina et al., 2004) are also employed to indicate the molecular weight evolution and the aromaticity degree (McDonald et al., 2004).

Other techniques used to quantify the HS biodegradation are the recovery and weighing of the remaining compounds (Burges and Latter, 1960; Mathur and Paul, 1967), the

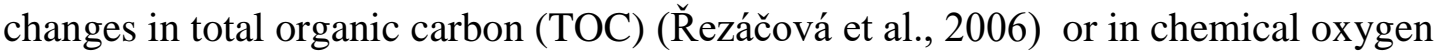
demand (COD) (Petrovic et al., 1993), and the measurement of the free fluorine (Wunderwald et al., 2000) or carbon dioxide (Haider and Martin, 1988; Hofrichter et al., 
1998; Steffen et al., 2002) generated during the mineralization of fluorinated or ${ }^{14} \mathrm{C}$ labelled polymers, respectively.

Besides quantification, characterization of HS, HA and FA before and after the fungal treatment is usually performed as well, by means of techniques such as elemental analysis, Fourier transform ion cyclotron resonance mass spectrometry, nuclear magnetic resonance (of ${ }^{13} \mathrm{C}$ or of $\mathrm{H}$ ) and size exclusion chromatography (largely the gel permeation type), being the last one the most utilized. Biodegradation can be accompanied by the increase, decrease or non-change in the modal mass (Gramss et al., 1999; Ralph et al., 1996), the presence of new low-molecular-weight peaks in the chromatograms (Grinhut et al., 2011a) and the reduction of phenolic levels, measured as vanillic acid (Belcarz et al., 2005; Kornillowicz-Kowalska et al., 2008). As one example, Fig. 1 illustrates the evolution of some of the chromatograms for coal HA. Fig. 1A shows a 168-h coal HA biodegradation by MnP from Clitocybula dusenii, showing a preferential attack on the high-molar-mass fractions and the formation of new peaks in the low-molar-mass range (Ziegenhagen and Hofrichter, 1998), whereas Fig. 1B reports a less selective attack and the no formation of new low-molecular-weight fragments during the 14-day degradation by Phanerochaete chrysosporium (Ralph and Catcheside, 1994).

\section{FIGURE 1}

It must be pointed out in Fig. 1B that the modal mass of the HA after 5 days of fungal biodegradation is higher than that at the beginning of the reaction, which suggests a certain degree of polymerization of the remaining HA. This repolymerization ability was observed in some ligninolytic enzymes (Hofrichter et al., 1998; Ikehata et al., 2004; Kulikova et al., 2013), and, depending on the experimental conditions, it can led to the 
apparition of new peaks in the big-size range (Hofrichter and Fritsche, 1997a) and/ or to an increase in the modal mass, temporarily (Ralph and Catcheside, 1998a) or permanently (Ralph and Catcheside, 1998b; Temp et al., 1999; Zavarzina et al., 2004).

Other parameters measured during the fungal biotreatment of HSs are the fungal growth and the enzyme activity. Bleaching is usually accompanied by a rise of the biomass weight. Nevertheless a higher growth rate does not always imply a better biodegradation (Dehorter and Blondeau, 1992; Ralph et al., 1996; Řezáčová et al., 2006; Zahmatkesh et al., 2016).

Regarding enzyme activities, they are estimated through oxidation of certain substrates, such as 2,2'-azinobis(3-ethylbenzthiazoline-6-sulphonate) by Lac and MnP (Steffen et al., 2002; Willmann and Fakoussa, 1997), syringaldazine by Lac (Fakoussa and Frost, 1999), 2,6-dimethyoxiphenol or vanillylacetone by MnP (Dehorter and Blondeau, 1992; Ralph and Catcheside, 1994), veratryl alcohol by LiP (Blondeau, 1989), 3,4dhydroxyphenylalanine by MMO (Gramss et al., 1999), guaicol by HRP (Belcarz et al., 2005) and anysalcohol by AAO (Kabe et al., 2005). The corresponding enzyme activity is expressed in terms of activity units (U), which reflect the micromoles of substrate consumed per minute, although occasionally they are also calculated as the change in the absorbance of substrates per minute (Dehorter and Blondeau, 1992; Zavarzina et al., 2004). At this point, it should be mentioned that the enzyme activities measured in absence of HS, are higher than those obtained in their presence (Blondeau, 1989; Hofrichter and Fritsche, 1997a; Ralph and Catcheside, 1994, 1998b, 1999; Zavarzina et al., 2004) or lower (Dehorter and Blondeau, 1992; Kluczek-Turpeinen et al., 2005; Steffen et al., 2002; Temp et al., 1999; Willmann and Fakoussa, 1997). Fig. 2 displays 
an example of these differences during the biodegradation of a coal HA by three different fungi.

\section{FIGURE 2}

Several authors have reported that the activity for a specific enzyme depends on the origin of the humic compounds (Belcarz et al., 2005; Claus and Filip, 1998;

Kornillowicz-Kowalska et al., 2008) and their concentration (Claus and Filip, 1998;

Willmann and Fakoussa, 1997; Zavarzina et al., 2004), the nutrients content (Ralph and Catcheside, 1994) and on the presence other substances (Dehorter and Blondeau, 1992; Ralph and Catcheside, 1999; Steffen et al., 2002) in the reaction medium, together with the availability of oxygen (Claus and Filip, 1998; Ralph and Catcheside, 1998a; Ralph et al., 1996).

\section{Fungal degradation}

Since the majority of the compiled papers deals with several matters, for the sake of clarity we have divided them in six tables (see supplementary material), depending on the studied variable.

\section{Effect of $C$ and $N$}

Table S1 groups the studies dealing with the effect of the presence of nutrients in the culture medium.

It can be seen in the works of Haider and Martin (1988) and Ralph and Catcheside (1994) (and of Blondeau (1989), Fakoussa and Frost (1999) and Grinhut et al. (2011b) if adsorption did not alter the general trends) that the higher the $\mathrm{C} / \mathrm{N}$ ratio, the higher the biodegradation. However, this is not a general rule, because the sucrose removal in the 
Czapek Dox broth fortified with yeast extract of Mathur (1970) did not worsen but enhanced the soil FA decolorization; HA degradation did not reach the highest percentage when the humic compound was the only source of nitrogen for the fungi of Mathur and Paul (1967), Khandelwal and Gaur (1980) and Mishra and Srivastava (1986); and two of the four fungi tested by Zahmatkesh et al.(2016) were more effective in the nitrogen supplemented medium than in the nitrogen limited one.

Taking into account that the absence of other sources of $\mathrm{N}$ and $\mathrm{C}$ led to equal or better performance than the presence of only $\mathrm{C}$ or only $\mathrm{N}$ for some microorganisms (Mathur and Paul, 1966, 1967; Mishra and Srivastava, 1986), it seems that the fungal decomposition of humic matter is a complex function of the $\mathrm{N}$ and $\mathrm{C}$ concentrations, and not only of the C/N ratio. Furthermore, if the data of Willman and Fakoussa (1997) and Fakoussa and Frost (1999) for adsorption plus biodegradation when HA was the only source of $\mathrm{C}$ or of $\mathrm{N}$ are extrapolable to biodegradation only, the fungal behavior turned out to be dependent on the nutrient source, and the results in different media will be not easily predictable (Gramss et al., 1999; Koukol et al., 2004; Mathur, 1969).

\section{Effect of reaction medium and operational conditions}

Table S2 includes those studies focused on the effect of the reaction medium and the operational conditions on the fungal degradation of HS.

Zahmetkesh et al. (2016), reported that the presence of an inhibitor of cytochrome P450 enzymes in the medium lowered the decolorization rate of the Trametes versicolor, thus probing that these enzymes were somehow implied in the decomposition of coal HA. Presence of $\mathrm{Mn}$ (II) stimulates the production of $\mathrm{MnP}$ (and of other enzymes at certain concentrations) and enhances the biodegradation (Steffen et al., 2002), although both, 
the $\mathrm{MnP}$ activity and the bleaching, tend to a plateau with increasing $\mathrm{Mn}$ (II) concentrations (Ralph and Catcheside, 1998a). Besides, if adsorption does not play an important role, in the findings of Grinhut et al. (2011b), it has been shown that $\mathrm{Mn}(\mathrm{II})$ is more effective in some media than in others.

Addition of veratryl alcohol increased the activities of $\mathrm{LiP}$ and $\mathrm{MnP}$ without improving the bleaching in the paper of Ralph and Catcheside (1998b), possibly due to competition between the oxidations of the HA and the veratryl alcohol by the enzymes. Dehorter and Blondeau (1992) reported the same behaviour than Ralph and Catcheside (1998b), but, since they do not inform if adsorption was taken into account, this phenomenon could mask their results (in fact, the abrupt reduction of absorbance in the first days of incubation are common hints of biosorption processes) (Petrovic et al., 1993; Temp et al., 1999).

With regards to operational variables, aeration (as shaking) turn out to have a negative effect on the attack to FA by Poria subacida (Mathur, 1969), and to FA and HA by Marasmius oreades (Mathur, 1970), but a positive one for the decolorization of HA by Penicillium frequentans (Mathur and Paul, 1966, 1967) and Cladosporium cladosporoides (Claus and Filip, 1998). Shaking enhances the nutrient distribution and oxygen transfer, but also breaks the fungal mycelium, so, there will be an optimal agitation speed for each case (Díaz, 2012; Hadibarata et al., 2013; Senthilkumar et al., 2014). A higher availability of dissolved oxygen from air in shallow cultures was the explanation of Ralph et al. (1996) to the higher bleaching and lower increases in modal mass in $10-\mathrm{mL}$ unshaken cultures when comparing it with $15-\mathrm{mL}$ unshaken ones (both contained in 1-L conical flasks). On the other hand, Ralph and Catcheside (1998a) recommended the use of pure oxygen instead of air during the fungal biodegradation, 
because the oxygenated media led to lower decolorization and to higher modal masses of the remaining HA.

Ralph and Catcheside (1998a) were also the only ones that analyzed the influence of temperature in fungal behavior, observing that results at $37^{\circ} \mathrm{C}$ were better than at $28^{\circ} \mathrm{C}$. They did not try to find the optimal temperature, that could be expected because the enzyme denaturalization and cell damage will increase at the higher temperatures.

\section{Effect of the initial concentration}

Table S3 summarizes the findings about the effects of the initial HS concentration on their fungal decomposition. Biodegradation rates of commercial HA by Trichoderma viride (Petrovic et al., 1993) and of soil FA by Poria subacida (Mathur, 1969) or Trichoderma viride (Petrovic et al., 1993) decreased when increasing the initial content of the humic material, whereas the attack to compost HA by Pecilomycetes inflatus (Kluczek-Turpeinen et al., 2005) improved.

Removal of ${ }^{14} \mathrm{C}$-labelled HA by Phanerochaete chrysosporium (Haider and Martin, 1988) and of soil HA by Trichoderma viride (Petrovic et al., 1993) remained almost insensitive to the initial amount of HA in the feed, but the bleaching of coal HA by Trametes versicolor (Fakoussa and Frost, 1999) or by the unclassified strain RBS 1k (Willmann and Fakoussa, 1997) went through a maximum with respect to the initial concentration of the HS. Nonetheless, it should be stressed that the maxima in removal rates were only seen by researchers who did not detach adsorption from biodegradation. In all the cases, the media contained additional sources of $\mathrm{C}$ and $\mathrm{N}$. 
The binding of chlorinated substances from herbicides and insecticides to the humic matrix did not always hinder the mineralization of these compounds, and sometimes, their degradation rate was higher than if not binded (Haider and Martin, 1988).

\section{Effect of the fungal species}

Table S4 collects those papers (or sections of papers) which compared: the bleaching of several HAs by one fungus (Belcarz et al., 2005; Haider and Martin, 1988;

Kornillowicz-Kowalska et al., 2008), of several HAs by several fungi (Yanagi et al., 2002), of one HA by several fungi or different strains of the same fungus (Burges and Latter, 1960; Dehorter et al., 1992; Fakoussa and Frost, 1999; Grinhut et al., 2011a; Kabe et al., 2005; Ralph and Catcheside, 1998b; Ralph et al., 1996; Yanagi et al., 2003) and of one HS or FA by two or more fungi (Gramss et al., 1999; Řezáčová et al., 2006; Temp et al., 1999).

At this point, it should be mentioned that, although some researchers do not take into account the HS biosorption by the fungus during the biodegradation process (Belcarz et al., 2005; Dehorter et al., 1992; Fakoussa and Frost, 1999; Grinhut et al., 2011a; Řezáčová et al., 2006; Yanagi et al., 2002), this phenomenon can be very important. For example, Gramms et al. (1999) noticed that the bleaching of soil HS by brown-rot fungi seemed higher than that of the white-rot ones if removal due to adsorption was not rested. Additionally, Gramms et al. (1999) also found that white-rot and brown-rot fungi were better than terricolous basidiomycetes, ectomycorrhizal fungi and soil-borne microfungi (with the exception of S. lignicola), whereas the brown-rot ones ( $F$. pinicola, $P$. betulinus) could led to higher biodegradations than some white-rot microorganisms (G. sapineus, K. mutabilis, P. ostreaus and S. rugoso-annulata). 


\section{Miscellany}

Table S5 included experiments which are not related with comparisons of nutrients, reaction media, operational conditions, HS concentrations or different fungi, and therefore, they could not be incorporated in the previous tables (Fakoussa and Frost, 1999; Mathur and Paul, 1966, 1967; Paul and Mathur, 1967; Willmann and Fakoussa, 1997; Wunderwald et al., 2000). It is worth stressing the results of Mathur and Paul (1966, 1967), Paul and Mathur (1967) and Willman and Fakoussa (1997), which reported an increase in the carboxylic groups and a decrease of the aromaticity of the HS after the fungal attack, either with or without adsorption of humic matter to the mycelium. This is in accordance with the studies of Claus and Filip (1998) and Grinhut et al. (2011a) and in opposition to the findings of Dehorter et al. (1992), cited in Tables S2 and S4. Taking into account that these three last works used the same microorganisms and medium, the behavior previously cited suggests an important biosorption in the work of Dehorter and Blondeau (1992), with a high attachment of the HA to the cells, stronger than in the works of Fakoussa and Frost (1999) and of Grinhut et al. (2011a).

\section{Enzymatic degradation}

Table S6 collects the experiments in the literature related to the bleaching of HS, HA or FA by fungal enzymes, in absence of the microorganism. The role of these enzymes in the biodegradation of humic compounds had semi-quantitatively been addressed by several authors (Tables S1 to S5), mainly studying if the increases in the enzymatic activity and in the HS decolorization are simultaneous In this regard, some authors, such as Ralph and coworkers (Ralph and Catcheside, 1994, 1998a, b; Ralph et al., 1996), Kabe et al. (2005) and Zahmatkesh et al. (2016) preferred the comparison 
between the decolorization degree with the activities measured in an HA-free medium, because it is alleged that HA interferes with assays for some enzymes, reducing their activities by formation of enzyme-HA complexes that do not oxidize the substrates (Ralph and Catcheside, 1994, 1998b; Wondrack et al., 1989).

In systems with one fungus and one or two enzymes, where agitation improved both biodegradation and enzyme activities (Claus and Filip, 1998), excretion of MnP and LiP in one medium was accompanied by bleaching, but the excretion of LiP alone in other medium caused not decolorization (Ralph and Catcheside, 1994). A strain that only produced MnP increased the modal mass of the remaining HA, but other strain, that generated both MnP and LiP, reduced it (Ralph and Catcheside, 1998b). When the parameters studied were temperature $\left(28\right.$ or $\left.37^{\circ} \mathrm{C}\right)$, veratryl alcohol (presence or absence) and atmosphere (oxygen or air), it seemed that the fungal attack was highly correlated with the enzyme activity (Ralph and Catcheside, 1998a). However, KluczekTurpeinen et al. (2005) noticed that during the degradation of compost HA by $P$. inflatus, only Lac was excreted, but that its activity decreased when increasing the HA concentration, whereas the bleaching followed the opposite trend. This suggests that lignolytic enzymes are necessary, but not sufficient, to accomplish the oxidation.

In articles where several fungi were tested, the correlation between bleaching and enzymatic activity became less evident, since the microorganims did not produce all the enzymes nor their activities allowed an easy comparison (Gramss et al., 1999; Ralph et al., 1996; Temp et al., 1999) or, simply, because the highest enzymatic activities did not correspond to the highest decolorizations (Gramss et al., 1999; Kornillowicz-Kowalska et al., 2008; Zahmatkesh et al., 2016). With this in mind, Gramss et al. (1999) reported that brown-rot basidiomycetes (e.g., F. pinicola), which did not produce extracellular 
phenol oxidases, decreased absorbance and altered the molecular weight of HS as effectively as white-rot basidiomycetes (e.g., $H$. frowardii), which produced all of these enzymes. The only exception is the work of Kabe et al. (2005), who compared three unidentified white-rot fungi, which generated four enzymes each one, and observed good correlation between decolorizations and depolymerizations with Lac and MnP activities.

When the HA removal due to adsorption was not taken into account, the majority of authors reported no correlation between both parameters (Dehorter and Blondeau, 1992; Fakoussa and Frost, 1999; Grinhut et al., 2011b; Řezáčová et al., 2006; Willmann and Fakoussa, 1997), although in some simple cases, the higher activities were linked to the higher bleachings (Belcarz et al., 2005; Blondeau, 1989; Steffen et al., 2002).

Considering these incongruences, Ralph and Catcheside (1998b), Wunderwald et al. (2000), Hofrichter and Fritsche (1997a) and Willman and Fakoussa (1997) tried to determine if $\mathrm{MnP}$ from fungi that were capable of bleaching humic compounds, could also decolorize the same substances in absence of the microorganisms. In the same way, this was the initial aim of Claus and Filip (1998) with Lac but they realized that the enzyme from the basidyomicete they had been working, displayed a very low activity, and preferred to utilize Lac from an ascomycete. Both Wunderwald et al. (2000) and Hofrichter and Fritsche (1997a) reported decreases in absorbance, but Willman and Fakoussa (1997) did not, a failure that these last ones tried to explain by the necessity of adsorption or proximity of the pollutants to the cell wall. Ralph and Catcheside (1998b) did not report absorbance reduction either, but noticed a rise in the modal mass, caused by the $\mathrm{Mn}(\mathrm{III})$ species, which also could cause a depolymerization if the atmosphere became more oxidant. 
Gramss et al. (1999) compared three (MMO, Lac, HRP) of the four enzymes generated by the microorganisms they had tested (see Table S4) with other three enzymes and two abiotic oxidants (one of them contained $\mathrm{Mn}^{3+}$ ). They also observed that HRP and the two abiotic oxidants gave the best HS removals, but since these researchers did not measure their activities, no useful information could be extracted from this comparison.

Other papers are focused on the optimization of the degradation process or on the better understanding of this process. Ziegenhagen and Hofrichter (1998) modified the amounts of HA, glutathione and organic solvents $\mathrm{N}, \mathrm{N}$-dimethylformamide and dimethylsulfoxide in order to improve the performance of MnP, Hofrichter et al. (1998) combined the same enzyme (but from other fungus) with several concentrations of the thiol mediator glutathione, Claus and Filip (1998) added $0-4 \mathrm{mmol} / \mathrm{L}$ of the redox mediator 1-hydroxybenzotriazole to Lac, and Zahmetkesh et al. (2016) compared four Lac mediators at $1 \mathrm{mmol} / \mathrm{L}$. Wondrack et al. (1989) varied $\mathrm{pH}$ and LiP, HA, veratryl alcohol and $\mathrm{H}_{2} \mathrm{O}_{2}$ concentrations during the degradation of coal $\mathrm{HA}$, but did not study all the combinations and left unspecified several parameters in their paper, which does not allow to know the optimum conditions. Also Ralph and Catcheside (1999) studied the effect of veratryl alcohol, $\mathrm{NaVO}_{3}$ and oxygen sparging on the oxidation of coal HA and methylated coal HA by LiP from P. chrysosporium. The results of these last ones, and those of Zavarzina et al. (2004) with Lac from P. tigrinus confirmed that the enzymatic action depends on the HA characteristics, and that the same experimental conditions can lead to depolymerization in one acid and to polymerization in others.

\section{Existence of metabolites}


The generation of substances from 0.08 to $0.8 \mathrm{kDa}$ observed in Fig. 1A is due to the fact that fungi or their enzymes do not always mineralize the HA or FA to $\mathrm{CO}_{2}$ completely. Occasionally, the amount of these low- and medium-molecular-weight degradation products can be important, new peaks appear in the chromatograms and the mass distribution, which was initially unimodal, becomes bimodal (Hofrichter et al., 1998; Grinhut et al., 2011a) or multimodal (Wondrack et al., 1989). In the degradation of lignite HA with LiP from Phanerochaete chrysosporium, variation of the experimental conditions can avoid their formation (Wondrack et al., 1989).

Nonetheless, the absence of new prominent peaks does not imply the absence of metabolite generation. Mathur and Paul (1967) separated chromatographically soil HA in four fractions (higher than $35 \mathrm{kDa}$, between 8 and $35 \mathrm{kDA}$, between 6 and $8 \mathrm{kDa}$ and lower than $6 \mathrm{kDa}$ ), finding that the lighter fraction was the most susceptible of suffering the attack by Penicillium frequentans (followed by the heaviest fraction). This suggested that, in the mixture of fractions, the larger molecules were not fully decomposed, but converted to intermediate and small-sized substances. By means of paper and gas chromatography, these authors found that two of these small-sized chemicals were salicyl alcohol and salicyl aldehyde (Mathur and Paul, 1966).

Gas chromatography was also employed by Ralph and Catcheside (1999) when dealing with the low-molecular-weight fraction from a methylated coal HA degraded by LiP from Phanerochaete chrysosporium in a medium with $\mathrm{H}_{2} \mathrm{O}_{2}$ and veratryl alcohol. They reported very small yields of fluoranthene, methyl 3,4-dimethoxybenzoate, transchrysanthenol, (E)-1-methylsuphinyl-2-phenylethene, 2,5-dimethoxyethylbenzene, 4,6dimethoxy-3(2H)-benzofuranone, 2,6-dimethoxytoluene, 4-methylbenzenecarbothioic acid $O$-methyl ester and methyl 3,4,5-trimethoxy-2-methylbenzoate. 
With regard to intermediate-sized metabolites, Gramss et al (1999) reported that the forest mull HS attacked by $F$. pinicola, L.deliciosus, $H$. crustuliniforme, S. lignicola, $S$. granulatus and $P$. involutus, generated optically active substances, some of which resembled melanins. For the last two fungi, these metabolites also interfered with the colorimetric and chromatographic measurements. When the HS was treated with $H$. frowardii and P. ostreatus, there was a production of mono- and polysaccharides based on hexose sugars.

In the degradated lignite HSs used by Temp et al (1999) and Hofrichter and Fritsche (1997), a decrease in the HA fraction and an increase in the FA one were detected, indicating that the FAs were the intermediate-sized metabolites, since they were generated instead of removed by the fungal/ enzymatic attack. When Fakoussa and Frost (1999), Kluczek-Turpeinen et al. (2005), Steffen et al. (2002), Wunderwald et al. (2000), Zahmatkesh et al. (2016) and Ziegenhagen and Hofrichter (1998) subjected their degradated HAs to an acid extraction, true FAs were also found in the supernatants.

\section{Comparison with other actual pollutants}

Bioremediation of complex effluents by fungi has generated a huge amount of literature. This has been partially compiled by Singh (2006), and there are also several specific reviews on textile (Bilal et al., 2017; Fu and Viraraghavan, 2001; Holkar et al., 2016; Rodriguez-Couto, 2009; Sen et al., 2016; Wesenberg et al., 2003), pulp and paper (Bajpai, 2012; Kamali and Khodaparast, 2015; Rubilar et al., 2008), olive mill (Mann, 2011; McNamara et al., 2008; Morillo et al., 2009) and brewery wastewaters (Pant and Adholeya, 2007; Satyawali and Balakrishnan, 2008). However, to the best of our 
knowledge, only one of the studies cited in those papers compares the degradation of one industrial pollutant with that of HA: the work of Belcarz et al (2005).

The main results reported by these authors were summarized in Table S4. They also tested the biodegradation of a daunomycin post-production stream with Bjerkandera adusta R59 in a liquid Park and Robinson medium with 10\% wastewater (total daunomycin content of $8.9 \mathrm{mg} / \mathrm{L}$ and phenolic levels of $11 \mathrm{mg} / \mathrm{L}$ ) at $26^{\circ} \mathrm{C}$ for 21 days. Decolorization (59\% at 7 days and $94 \%$ beyond 14 days) was higher than that of HAs from lessive soil or from chernozen in a Fahreus medium, but phenolic levels were higher $(4.86 \mathrm{mg} / \mathrm{L}$ at the end of the experiment $)$ and the peroxidase activity went through a maximum at 7 days instead of at 14 days.

\section{Conclusions and future gaps}

HS can be considered as model compounds of several types of pollutants present in wastewaters. Fungi (and especially those from the white-rot type) attack and decompose HA and FA mainly through extracellular ligninolytic enzymes (Lac, MnP and LiP). The effectiveness of the biodegradation has shown to be a complex function of reaction time, type of fungus, inoculation mode, type of $\mathrm{C}$ and $\mathrm{N}$ sources and their concentrations, origin, composition and concentration of the HS, presence of promoters or inhibitors of the fungal growth or of fungal activity, $\mathrm{pH}$, temperature and aeration, and therefore, they have to be optimized for each individual HS and fungus. Additionally, the cells can remove part of the HS by means of adsorption, and this should be taken into account for either the use or disposal of the excess biomass. 
The use of ligninolytic enzymes has proven to be an alternative to the utilization and characterization of fungi, since their activity in the liquid medium does not depend on nutrients and fungus metabolism. However, the costs associated to their production and separation reduces the competiveness of this option when compared to the biomassbased processes.

However, there is much work remaining to be done. For instance, the effects of variables related to the scale-up of the biotreatment, such as the fungal immobilization or the interactions between fungi and bacteria (for bioaugmentation processes or during the treatment of NOM or leachates, for example) have not yet been studied. There is a lack on in-depth knowledge about the characterization/quantification of the intermediates and products generated during the biodegradation. Additionally, their separation and recovery have not been considered. In a similar way, the effects of fungal treatment on the subsequent discharge or downstream processing of the effluent are unknown.

Fig. 3 shows a scheme of the different variables with effect on the biodegradation of humic and fulvic acids by fungi, giving an idea of those gaps that will need more research.

\section{FIGURE 3}

\section{Acknowledgements}

We are grateful to Prof. Dr. José Ramón Álvarez, for his help during the literature search.

\section{Supplementary data}


Tables S1- S6

\section{Ethical Standards}

Sergio Collado declares that he has no conflict of interest.

Paula Oulego declares that she has no conflict of interest.

Octavio Súarez-Iglesias declares that he has no conflict of interest.

Mario Díaz declares that he has no conflict of interest.

This article does not contain any studies with human participants or animals performed by any of the authors.

\section{References}

Bajpai P (2012) Biotechnology for pulp and paper processing. Springer Science + Business Media, LLC, New York.

Belcarz A., Ginalska G, Kornillowicz-Kowalska T (2005) Extracellular enzyme activities of Bjerkandera adusta R59 soil strain, capable of daunomycin and humic acids degradation. Appl. Microbiol. Biotechnol. 68(5), 686-694.

Bhatnagar A, Sillanpää M (2017) Removal of natural organic matter (NOM) and its constituents from water by adsorption: a review. Chemosphere, 166, 497-510.

Bilal M, Asgher M, Parra-Saldivar R, Hu H, Wang W, Zhang X, Iqbal HMN (2017) Immobilized ligninolytic enzymes: an innovative and environmenal responsive technology to tackle dye-based industrial pollutants- a review. Sci. Total Environ. 576, 646 - 659

Blondeau R (1989) Biodegradation of natural and synthetic humic acids by the white rot fungus Phanerochaete chrysosporium. Appl. Environ. Microbiol. 55(5), 12821285. 
Burges A, Latter P (1960) Decomposition of humic acid by fungi. Nature 186(4722), 404-405.

Claus H, Filip Z (1998) Degradation and transformation of aquatic humic substances by laccase-producing fungi Cladosporium cladosporioides and Polyporus versicolor. Acta Hydrochim. Hydrobiol. 26(3), 180-185.

Dehorter B, Blondeau R (1992) Extracellular enzyme activities during humic acid degradation by the white rot fungi Phanerochaete chrysosporium and Trametes versicolor. FEMS Microbiol. Lett. 94(3), 209-215.

Dehorter B, Kontchou CY, Blondeau R (1992) ${ }^{13}$ C NMR spectroscopic analysis of soil humic acids recovered after incubation with some white rot fungi and actinomycetes. Soil Biol. Biochem. 24(7), 667-673.

Díaz M (2012) Bioprocess Engineering. Paraninfo, Madrid. (in Spanish)

Elbeyli İY, Palantöken A, Pişkin S, Peksel A, Kuzu H (2006) Bioliquefaction/solubilization of lignitic humic acids by white-rot fungus Phanerochaete chrysosporium. Energy Sources, Part A. 28(11), 1051-1061.

Fakoussa RM, Frost PJ (1999) In vivo-decolorization of coal-derived humic acids by laccase-excreting fungus Trametes versicolor. Appl. Microbiol. Biotechnol. 52(1), 60-65.

Fu Y, Viraraghavan T (2001) Fungal decolorization of dye wastewaters: a review. Bioresour. Technol. 79, 251 - 262.

Gao J, Oloibiri V, Chys M, Audenaert W, Decostere B, He Y, Van Langenhove H, Demeestere K, Van Hulle SWH (2015) The present status of landfill leachate treatment and its development trend from a technological point of view. Rev. Environ. Sci. Bio/Technol. 14(1), 93-122. 
Gramss G, Ziegenhagen D, Sorge S (1999) Degradation of soil humic extract by woodand soil-associated fungi, bacteria, and commercial enzymes. Microb. Ecol. $37(2), 140-151$.

Granit T, Chen Y, Hadar Y (2007) Humic acid bleaching by white-rot fungi isolated from biosolids compost. Soil Biol. Biochem. 39(5), 1040-1046.

Grinhut T, Hadar Y, Chen Y (2007) Degradation and transformation of humic substances by saprotrophic fungi: processes and mechanisms. Fungal Biol. Rev. 21(4), 179-189.

Grinhut T, Hertkorn N, Schmitt-Kopplin P, Hadar Y., Chen Y. (2011a) Mechanisms of humic acids degradation by white rot fungi explored using ${ }^{1} \mathrm{H}$ NMR spectroscopy and FTICR mass spectrometry. Environ. Sci. Technol., 45(7), $2748-2754$.

Grinhut T, Salame TM, Chen Y, Hadar Y (2011b) Involvement of ligninolytic enzymes and Fenton-like reaction in humic acid degradation by Trametes sp. Appl. Microbiol. Biotechnol. 91(4), 1131-1140.

Hadibarata T, Adnan LA, Yusoff ARM, Yuniarto A, Rubiyatno, Zubir MMFA, Khudhair AB, Teh ZC, Naser MA (2013) Microbial decolorization of an azo dye reactive black 5 using white-rot fungus Pleurotus eryngii F032. Water, Air, Soil Pollut. 224(6), 1595.

Haider KM, Martin JP (1988) Mineralization of ${ }^{14} \mathrm{C}$-labelled humic acids and of humicacid bound ${ }^{14} \mathrm{C}$-xenobiotics by Phanerochaete chrysosporium. Soil Biol. Biochem. 20(4), 425-429.

Hofrichter M, Fritsche W (1996) Depolymerization of low-rank coal by extracellular fungal enzyme systems. Appl. Microbiol. Biotechnol. 46(3), 220-225. 
Hofrichter M, Fritsche W (1997a) Depolymerization of low-rank coal by extracellular fungal enzyme systems. III.In vitro depolymerization of coal humic acids by a crude preparation of manganese peroxidase from the white-rot fungus Nematoloma frowardii b19. Appl. Microbiol. Biotechnol. 47(5), 566-571.

Hofrichter M, Fritsche W (1997b) Depolymerization of low-rank coal by extracellular fungal enzyme systems. II. The ligninolytic enzymes of the coal-humic-aciddepolymerizing fungus Nematoloma frowardii b19. Appl. Microbiol. Biotechnol. 47(4), 419-424.

Hofrichter M, Scheibner K, Schneegaß I, Ziegenhagen D, Fritsche W (1998) Mineralization of synthetic humic substances by manganese peroxidase from the white-rot fungus Nematoloma frowardii. Appl. Microbiol. Biotechnol. 49(5), 584-588.

Holkar CR, Jadhav AJ, Pinjari DV, Mahamuni NM (2016) A critical review on textile wastewater treatments: posible approaches. J. Env. Manage. 182, 351 - 366.

Hurst HM, Burges A, Latter P (1962) Some aspects of the biochemistry of humic acid decomposition by fungi. Phytochemistry 1(4), 227-231.

Ikehata K, Buchanan ID, Smith DW (2004) Recent developments in the production of extracellular fungal peroxidases and laccases for waste treatment. J. Environ. Eng. Sci. 3(1), 1-19.

Kabe Y, Osawa T, Ishihara A, Kabe T (2005) Decolorization of coal humic acid by extracellular enzymes produced by white-rot fungi. Coal Prep. (Philadelphia, PA, U.S.) 25(4), 211-220.

Kamali M, Khodaparast Z (2015) Review on recent developments on pulp and paper mill wastewater treatment. Ecotoxicol. Environ. Saf. 114, 326 - 342. 
Khandelwal KC, Gaur AC (1980) Degradation of humic acids, extracted from manure and soil by some streptomycetes and fungi. Zentralbl. Bakteriol., Parasitenkd., Infektionskrankh. Hyg., Abt. 2, Naturwiss.: Allg., Landwirtsch. Tech. Mikrobiol. 135(2), 119-122.

Kim H-C, Dempsey BA (2013) Membrane fouling due to alginate, SMP, EfOM, humic acid, and NOM. J. Membr. Sci. 428, 190-197.

Kluczek-Turpeinen B, Steffen KT, Tuomela M, Hatakka A, Hofrichter M (2005) Modification of humic acids by the compost-dwelling deuteromycete Paecilomyces inflatus. Appl. Microbiol. Biotechnol. 66(4), 443-449.

Kornillowicz-Kowalska T, Ginalska G, Belcarz A, Iglik H (2008) Decolorization of humic acids and alkaline lignin derivative by an anamorphic Bjerkandera Adusta R59 strain isolated from soil. Pol. J. Environ. Stud. 17(6), 903 - 909.

Koukol O, Gryndler M, Novák F, Vosátka M (2004) Effect of Chalara longipes on decomposition of humic acids from Picea abies needle litter. Folia Microbiol. (Dordrecht, Neth.) 49(5), 574-578.

Kües U (2015) Fungal enzymes for environmental management. Curr. Opin. Biotechnol. 33, 268-278.

Kulikova NA, Davidchik VN, Tsvetkova EA, Koroleva OV (2013) Interaction of coal humic acids with fungal laccase. Adv. Microbiol. (Irvine, CA, U.S.) 3, 145 153.

Mann J (2011) Microbial bioremediation of olive mill wastewater. Ph.D. Thesis. University of Western Sydney Hawkesbury, Richmond, New South Wales, Australia

Mathur SP (1970) Degradation of soil humus by the fairy ring mushroom. Plant Soil, 33(1) 717-720. 
Mathur S P (1969) Microbial use of podzol Bh fulvic acids. Can. J. Microbiol. 15(7), 677-680.

Mathur SP, Paul EA (1967) Microbial utilization of soil humic acids. Can. J. Microbiol. 13(5), 573-580.

Mathur SP, Paul EA (1966) A microbiological approach to the problem of soil humic acid structures. Nature 212(5062), 646-647.

McDonald S, Bishop AG, Prenzler PD, Robards K (2004) Analytical chemistry of freshwater humic substances. Anal. Chim. Acta 527(2), 105-124.

McNamara CJ, Anastasiou CC, O'Flaherty V, Mitchell R (2008) Bioremediation of olive mill wastewater. Int. Biodeterior. Biodegradation 61, 127 - 134.

Mishra B, Srivastava LL (1986) Degradation of humic acid of a forest soil by some fungal isolates. Plant Soil 96(3), 413-416.

Morillo JA, Antizar-Ladislao B, Monteoliva-Sánchez M, Ramos-Cormenzana A, Russell NJ (2009) Bioremediation and biovalorisation of olive-mill wastes. Appl. Microbiol. Biotechnol. 82, 25 - 39.

Oulego P, Collado S, Laca A, Díaz M (2015) Tertiary treatment of biologically pretreated landfill leachates by non-catalytic wet oxidation. Chem. Eng. J. 273, 647-655.

Oulego P, Collado S, Laca A, Díaz M (2016) Impact of leachate composition on the advanced oxidation treatment. Water Res. 88, 389-402.

Pant D, Adholeya A (2007) Biological approaches for treatment of distillery wastewater: a review. Bioresour. Technol. 98, 2321 - 2334.

Paul EA, Mathur SP (1967) Cleavage of humic acids by Penicillium frequentans. Plant Soil 27(2), 297 - 299. 
Petrovic M, Briski F, Kastelan-Macan M (1993) Biosorption and biodegradation of humic substances by Trichoderma viride. Prehrambeno-technol. Biotechnol. Rev. 31(4), 145 - 149.

Pointing S (2001) Feasibility of bioremediation by white-rot fungi. Appl. Microbiol. Biotechnol. 57(1), 20-33.

Ralph JP, Catcheside DEA (1994) Decolourisation and depolymerisation of solubilised low-rank coal by the white-rot basidiomycete Phanerochaete chrysosporium. Appl. Microbiol. Biotechnol. 42(4), 536-542.

Ralph JP, Catcheside DEA (1998a) Influence of culture parameters on extracellular peroxidase activity and transformation of low-rank coal by Phanerochaete chrysosporium. Appl. Microbiol. Biotechnol. 49(4), 438-444.

Ralph JP, Catcheside DEA (1998b) Involvement of manganese peroxidase in the transformation of macromolecules from low-rank coal by Phanerochaete chrysosporium. Appl. Microbiol. Biotechnol. 49(6), 778-784.

Ralph JP, Catcheside DEA (1999) Transformation of macromolecules from a brown coal by lignin peroxidase. Appl. Microbiol. Biotechnol. 52(1), 70-77.

Ralph JP, Graham LA, Catcheside DEA (1996) Extracellular oxidases and the transformation of solubilised low-rank coal by wood-rot fungi. Appl. Microbiol. Biotechnol. 46(3), 226-232.

Řezáčová V, Hršelová H, Gryndlerová H, Mikšík I, Gryndler M (2006) Modifications of degradation-resistant soil organic matter by soil saprobic microfungi. Soil Biol. Biochem. 38(8), 2292-2299.

Rodríguez-Couto S (2009) Dye removal by immobilised fungi. Biotechnol. Adv. 27, $227-235$. 
Rubilar O, Diez MC, Gianfreda L (2008) Transformation of chlorinated phenolic compounds by white rot fungi. Crit. Rev. Environ. Sci. Technol. 38, 227 - 268.

Sankaran S, Khanal SK, Jasti N, Jin B, Pometto AL, Van Leeuwen JH (2010) Use of filamentous fungi for wastewater treatment and production of high value fungal byproducts: a review. Crit. Rev. Environ. Sci. Technol. 40(5), 400-449.

Satyawali Y, Balakrishnan M (2008) Wastewater treatment in molasses-based alcohol distilleries for COD and color removal: a review. J. Environ. Manage. 86, 481 497.

Sen SK, Raut S, Bandyopadhyay P, Raut S (2016) Fungal decolouration and degradation of azo dyes: a review. Fungal Biol. Rev. 30, 112 - 133.

Senthilkumar S, Perumalsamy M, Janardhana Prabhu H (2014) Decolourization potential of white-rot fungus Phanerochaete chrysosporium on synthetic dye bath effluent containing Amido black 10B. J. Saudi Chem. Soc. 18(6), 845-853.

Singh H (2006) Mycoremediation: fungal bioremediation. John Wiley \& Sons, Inc., Hoboken, New Jersey.

Šnajdr J, Steffen KT, Hofrichter M, Baldrian P (2010) Transformation of ${ }^{14}$ C-labelled lignin and humic substances in forest soil by the saprobic basidiomycetes Gymnopus erythropus and Hypholoma fasciculare. Soil Biol. Biochem. 42(9), $1541-1548$.

Steffen KT, Hatakka A, Hofrichter M (2002) Degradation of humic acids by the litterdecomposing basidiomycete Collybia dryophila. Appl. Environ. Microbiol. 68(7), 3442-3448.

Steffen KT, Hofrichter M, Hatakka A (2000) Mineralisation of ${ }^{14} \mathrm{C}$-labelled synthetic lignin and ligninolytic enzyme activities of litter-decomposing basidiomycetous fungi. Appl. Microbiol. Biotechnol. 54(6), 819-825. 
Stevenson FJ (1994) Humus Chemistry: Genesis, Composition, Reactions, Wiley \& Sons, New York.

Tan KH (2014) Humic matter in soil and the environment: principles and controversies. 2nd ed. CRC Press., Boca Ranton.

Temp U, Meyrahn H, Eggert C (1999) Extracellular phenol oxidase patterns during depolymerization of low-rank coal by three basidiomycetes. Biotechnol. Lett. 21(4), 281-287.

Tortella GR, Diez MC, Durán N (2005) Fungal diversity and use in decomposition of environmental pollutants. Crit. Rev. Microbiol. 31(4), 197-212.

Wesenberg D, Kyriakides I, Agathos SN (2003) White-rot fungi and their enzymes for the treatment of industrial dye effluents. Biothechnol. Adv. 22, 161 - 187.

Willmann G, Fakoussa RM (1997) Biological bleaching of water-soluble coal macromolecules by a basidiomycete strain. Appl. Microbiol. Biotechnol. 47(2), 95-101.

Wondrack L, Szanto M, Wood WA (1989) Depolymerization of water soluble coal polymer from subbituminous coal and lignite by lignin peroxidase. Appl. Biochem. Biotechnol. 20(1), 765.

Wunderwald U, Kreisel G, Braun M, Schulz M, Jäger C, Hofrichter M (2000) Formation and degradation of a synthetic humic acid derived from 3fluorocatechol. Appl. Microbiol. Biotechnol. 53(4), 441-446.

Yadav M, Yadav H.S (2015) Applications of ligninolytic enzymes to pollutants, wastewater, dyes, soil, coal, paper and polymers. Environ. Chem. Lett. 13(3), 309-318. 
Yanagi Y, Hamaguchi S, Tamaki H, Suzuki T, Otsuka H, Fujitake N (2003) Relation of chemical properties of soil humic acids to decolorization by white rot fungus Coriolus consors. Soil Sci. Plant Nutr. (Abingdon, U. K.) 49(2), 201-206.

Yanagi, Y, Tamaki H, Otsuka H, Fujitake N (2002) Comparison of decolorization by microorganisms of humic acids with different ${ }^{13} \mathrm{C}-\mathrm{NMR}$ properties. Soil Biol. Biochem. 34(5), 729-731.

Zahmatkesh M, Spanjers H, Toran MJ, Blánquez P, van Lier JB (2016) Bioremoval of humic acid from water by white rot fungi: exploring the removal mechanisms. AMB Express 6(1), 118.

Zavarzina AG, Leontievsky AA, Golovleva LA, Trofimov SY (2004)

Biotransformation of soil humic acids by blue laccase of Panus tigrinus 8/18: an in vitro study. Soil Biol. Biochem. 36(2), 359-369.

Zhou JL, Banks CJ (1993) Mechanism of humic acid colour removal from natural waters by fungal biomass biosorption. Chemosphere 27(4), 607-620.

Ziegenhagen D, Hofrichter M (1998) Degradation of humic acids by manganese peroxidase from the white-rot fungus Clitocybula dusenii. J. Basic Microbiol. 38(4), 289-299. 
Figure 1
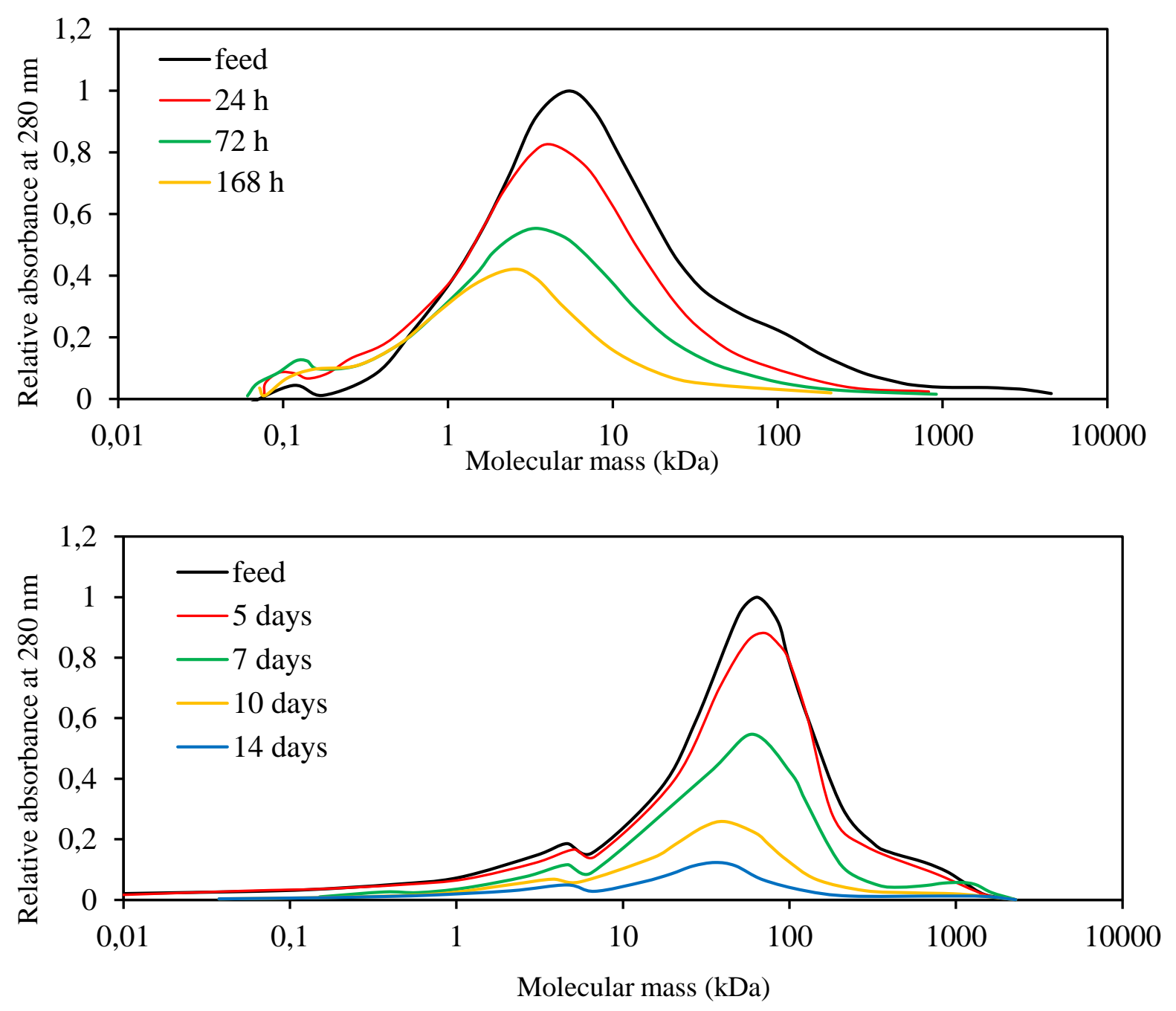


\section{Figure 2}
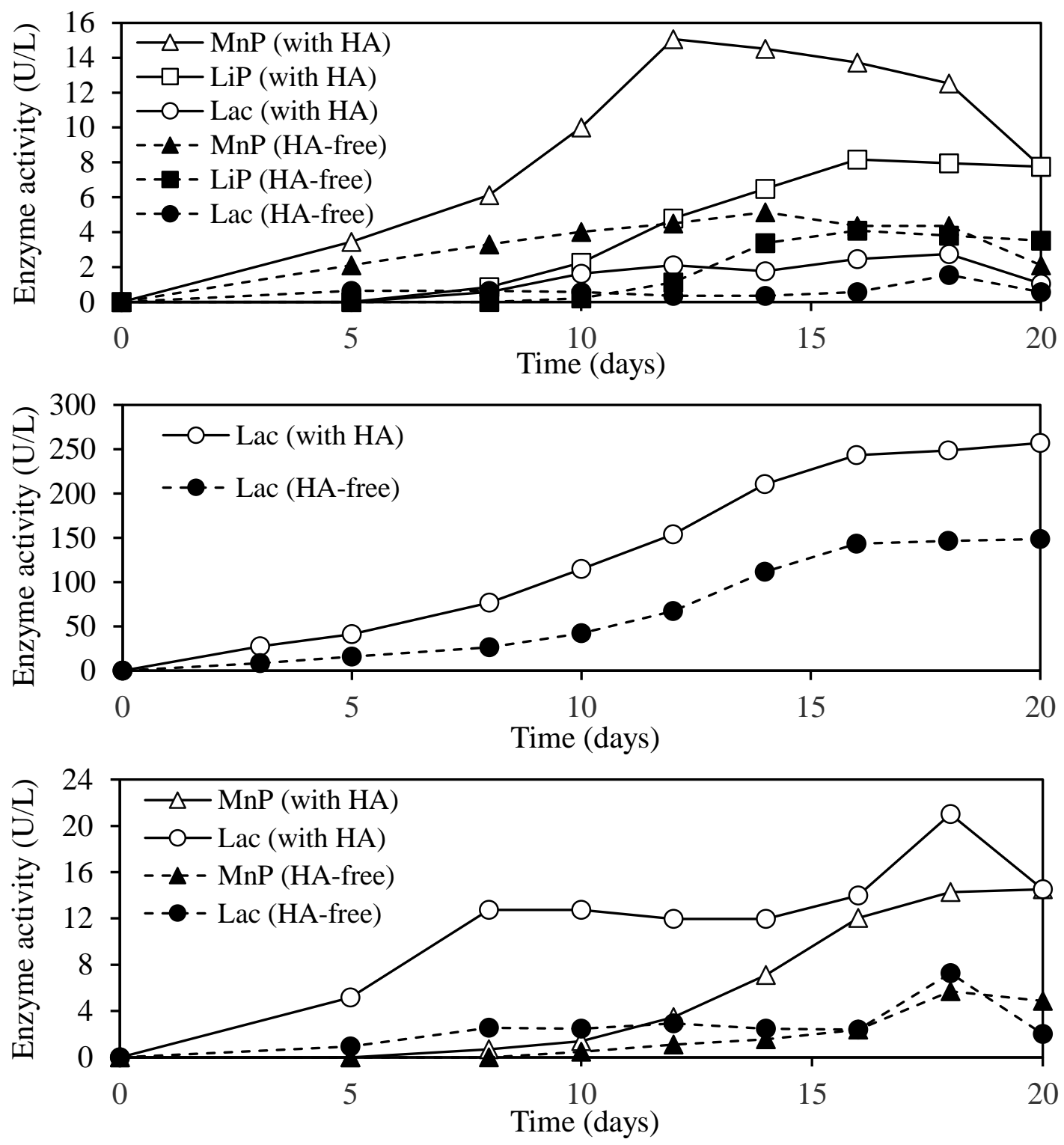
Figure 3

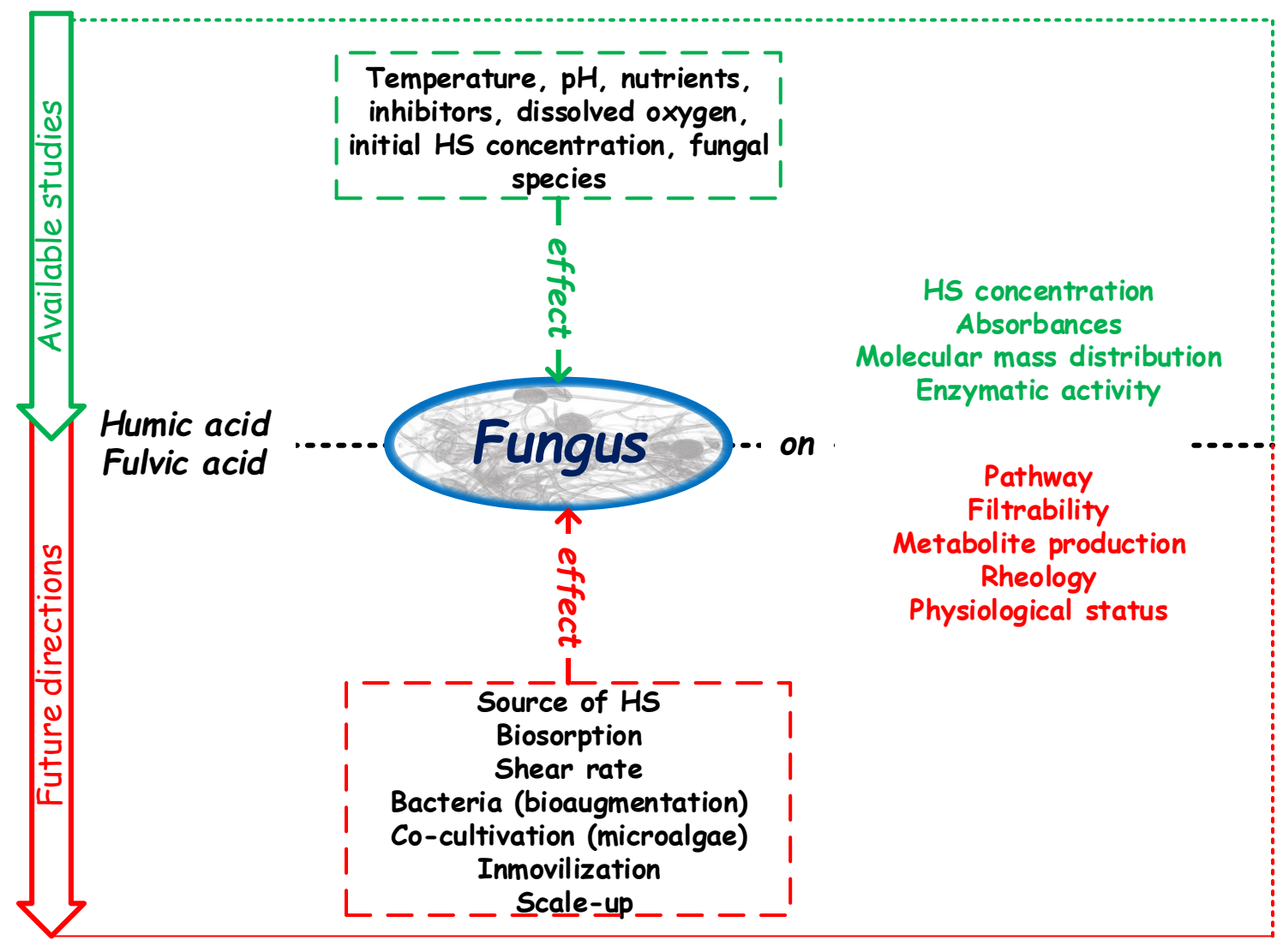




\section{Figure captions}

Fig. 1. Time-evolution of the molecular mass distribution for a) coal HA attacked by MnP from Clitocybula dusenii according to Ziegenhagen and Hofrichter (1998) and for

b) coal HA degradated by Phanerochaete chrysosporium according to Ralph and

Catcheside (1994). For further information, see Tables S6 and S1, respectively.

Fig. 2. Variation of the enzymatic activities with time in media with and without HS for a) basidiomycete JF 596, b) Pycnoporus cinnabarinus and c) Polyporus ciliatus according to Temp et al. (1999). For further details, see Table S4.

Figure 3.- Summary of the available studies and the future directions on the identified knowledge gaps related to the fungal biotreatment of humic substances. 



\section{Supplementary material for}

\section{BIODEGRADATION OF DISSOLVED HUMIC SUBSTANCES BY FUNGI. A REVIEW}

Sergio Collado ${ }^{a}$, Paula Oulego ${ }^{a}$, Octavio Suárez-Iglesias ${ }^{a}$, Mario Díaz $^{a *}$

${ }^{a}$ Department of Chemical and Environmental Engineering. University of Oviedo.

C/ Julián Clavería s/n. E-33071 Oviedo, Spain. Tel.:34985103439; Fax: 34985103434

*mariodiaz@uniovi.es 


\section{Table of contents:}

Table S1. Influence of nutrients in the fungal decolorization of humic compounds.

Table S2. Influence of reaction medium and operational conditions in the fungal decolorization of humic compounds.

Table S3. Influence of feed concentration in the fungal decolorization of humic compounds.

Table S4. Comparison of several fungi or of humic compounds under the same experimental conditions for the bleaching.

Table S5. Operational features of some fungal decolorizations, not previously cited.

Table S6. Decolorization of humic compounds by means of fungal enzymes alone. 


\section{Table S1}

Influence of nutrients in the fungal decolorization of humic compounds.

\begin{tabular}{ll}
\hline Autor & Fungi, medium and experimental conditions \\
\hline Mathur and & $\bullet$ HA from the Ap horizon of Melfort Orthic Black soil. \\
Paul (1967) & $\bullet$ Seven fungi (two Penicillium frequentans, Aspergillus \\
& $\begin{array}{l}\text { versicolor, Fusarium sp, Cephalosporium sp., } \\
\text { Cunninghamella sp. and Penicillium } 895) \text { isolated from } \\
\text { that soil. }\end{array}$
\end{tabular}

- $0.2 \%$ HA in a Czapek Dox broth without sucrose, nitrate or both, inoculated with 48-h old washed cells and shook at room temperature for 4 weeks.

Comments and results

- Prior to measurements, cells were separated and washed with a buffer to recover the HA adsorbed by them. Washing was added to the solution.

- When HA was supplied as the sole source of $\mathrm{C}$, decolorizations (decreases of absorbance at $465 \mathrm{~nm}$ ) were $19.2 \%$ for one $P$. frequentans, $3.8 \%$ for the other $P$. frequentans and for Fusarium sp., $9.6 \%$ for $A$. versicolor, and $7.7 \%$ for Cephalosporium sp., Cuninghamella sp. and Penicillium 895. When the acid was the sole source of $\mathrm{N}$, bleachings were $17.3 \%$ for one $P$. frequentans, $3.8 \%$ for the other $P$. frequentans, $-11.5 \%$ for A. versicolor, $5.7 \%$ for Fusarium sp., Cephalosporium sp. and Penicillium 895, and 7.7\% for Cuninghamella sp. When HA was the sole source of both $\mathrm{C}+\mathrm{N}$, degradations were $17.3 \%$ for one $P$. frequentans, $7.7 \%$ for the other $P$. frequentans, for Cephalosporium sp. and for Cuninghamella sp., $5.7 \%$ for A. versicolor and Fusarium sp., and $11.5 \%$ for Penicillium 895.

Mathur and

Paul (1966, 1967)
- HA from the Ap horizon of Melfort Orthic Black soil, with $54 \%$ C, $4.76 \% \mathrm{H}, 3.89 \% \mathrm{~N}$ and $37.4 \% \mathrm{O}$ (ash-free)

- Penicillium frequentans from the same soil

- $0.02 \%$ HA in a Czapek Dox broth without sucrose, nitrate or both. Inoculation with mycelium or spores and incubation for 7 weeks at room temperature with or without shaking.
- Prior to measurements, cells were separated and washed with a buffer to recover the HA adsorbed by them. Washings was added to the cultures.

- In the stationary culture inoculated with mycelium, the HA mass decreased a $10.2 \%$ when HA was the source of $\mathrm{C}$ and a $6.2 \%$ when it was the source of N. No measurements were done when it was the source of both $\mathrm{C}$ and $\mathrm{N}$.

- In the shaken culture inoculated with spores, the absorbance at $465 \mathrm{~nm}$ decreased a $6.6 \%$ when $\mathrm{HA}$ was the source of $\mathrm{C}$, a $5 \%$ when it was the source of $\mathrm{N}$ and a $6.6 \%$ when it was the source of both $\mathrm{C}$ and $\mathrm{N}$.

- In the shaken culture inoculated with mycelium, the absorbance at $465 \mathrm{~nm}$ decreased a $31.6 \%$ when $\mathrm{HA}$ was the source of $\mathrm{C}$, a $30 \%$ when it was the source of $\mathrm{N}$ and a $35 \%$ when it was the source of both $\mathrm{C}$ and $\mathrm{N}$. 


\begin{tabular}{|c|c|c|}
\hline Autor & Fungi, medium and experimental conditions & Comments and results \\
\hline
\end{tabular}

Mathur (1969)

- FA from the Bh horizon of Armadale soil

- The white-rot fungus Poria subacida 17780

- 200-mL Erlenmeyer flasks containing 25 mL CzapekDox broth fortified with $0.02 \%$ yeast extract at $\mathrm{pH} 5.0$, with $0.05 \% \mathrm{FA}$, inoculated with 72 -h cultures and incubated at $28^{\circ} \mathrm{C}$ without shaking for 24 days.

- 300-mL Erlenmeyer flasks containing Czapek-Dox broth without sugar at $\mathrm{pH} 5,0.05 \% \mathrm{FA}$ as the sole source of carbon and inoculated with fungal pellets. Incubation at $28^{\circ} \mathrm{C}$ without shaking for $48 \mathrm{~h}$

Mathur (1970)

- HA from chernozem and FA from podzol

- Basidiomycete Marasmius oreades, also called the fairy ring mushroom.

- 200-mL flask with 25 mL of Czapek Dox broth, $0.02 \%$ yeast extract and 460 ppm HA or 470 ppm FA, inoculated with one loopful (1-mm size) of homogenized culture and incubated at $24^{\circ} \mathrm{C}$ for 4 weeks without shaking.

- 200-mL flask containing $25 \mathrm{~mL}$ of Czapek Dox broth without sugar but with $0.02 \%$ yeast extract and $468 \mathrm{ppm}$ HA or 475 ppm FA, inoculated with $0.6 \mathrm{~g}$ wet cells and incubated at $24^{\circ} \mathrm{C}$ for 1 week without shaking
- Solutions with FA adsorbed on mycelia served as controls in color comparisons. Pellets were presoaked in FA to avoid adsorption during the degradation. At the end of the experiments, all the FA on the cells was recovered by washing with $1 \% \mathrm{~K}_{3} \mathrm{PO}_{4}$.

- In the Czapek-Dox broth fortified with yeast extract, decolorizations (reduction of absorbances at $465 \mathrm{~nm}$ ) were of $3.8 \%$ after 10 days, $25.38 \%$ after 18 days and $45.3 \%$ after 24 days.

- In the Czapek-Dox broth without sugar, decolorization was of $66.7 \%$ after $48 \mathrm{~h}$

- For eliminating the effect of fungal absorption, controls were carried out with two sets of flasks: one containing medium + FA or HA but let uninoculated and the other inoculated but without FA or HA. Concentrations were determined by absorbances at $465 \mathrm{~nm}$.

- In the Czapek Dox medium with yeast extract, the concentrations of HA and FA decreased a $22 \%$ and a $39 \%$, respectively, after 4 weeks.

- In the medium without sucrose, the concentration of HA decreased a $15 \%$ after $4 \mathrm{~h}$ and $18 \%$ after 1 week, whereas the FA content decreased a $44 \%$ at $4 \mathrm{~h}$ and a $51 \%$ at 1 week. 


\begin{tabular}{ll}
\hline Autor & Fungi, medium and experimental conditions \\
\hline Khandelwal and & $\bullet$ HA from alluvial soil and farmyard manure
\end{tabular}

Gaur (1980)

HA from alluvial soil and farmyard manure

- Fusarium solani (F 5), Penicillium roseopurpureum (F 5) and Aspergillus fumigatus (F 7)

- Broth with HA as the sole source of either carbon, nitrogen or both and also in the presence of glucose $(0.25 \%)$ and ammonium sulphate $(0.1 \%)$, inoculated with spore suspensions from 5-day-old fungal and 14day-old bacterial cultures and incubated for 40 days.

Mishra and

Srivastava (1986)
- HA from an Alfisol

- Aspergillus sp. from Bangalore, Ranchi and Calcuta, Aspergillus awamori, Humicola insolens, Paeceliomyces fusisproms, Penicillium sp, Trichurus spiralis and Trichoderma viride.

- 250-mL conical flasks containing $50 \mathrm{ml}$ of Czapek-Dox medium with $0.1 \% \mathrm{HA}(\mathrm{w} / \mathrm{v})$, but excluding (i) sucrose, (ii) nitrate or (iii) nitrate and sucrose, in order to fix HA as the sole source of (i) carbon, (ii) nitrogen and (iii) carbon and nitrogen. Inoculation with $10 \mathrm{~mL}$ suspension in sterile water of a 72 hour old culture grown on Czapeck-Dox agar slope, containing $19 \times 10^{4} / \mathrm{mL}$ viable cells. Incubation at $30^{\circ} \mathrm{C}$ for 6 weeks
Comments and results

- Prior to measurements, cells were separated and washed with $\mathrm{NaOH}$ to recover the HA adsorbed by them. Washing was added to the solutions.

- When the manure HA was supplied as the sole source of $\mathrm{C}$, decolorizations (\% reduction of absorbance at $430 \mathrm{~nm}$ ) were $13.3 \%$ for $F$. solani, $12.2 \%$ for $P$. roseopurpureum and $24.4 \%$ for $A$. fumigatus. When the same HA was supplied as the sole source of $\mathrm{N}$, they were $22.5 \%$ for $F$. solani, $17.8 \%$ for $P$. roseopurpureum and $15.6 \%$ for $A$. fumigatus. If HA was the sole source of both $\mathrm{C}$ and $\mathrm{N}$, bleachings were $9.2 \%$ for $F$. solani, $10.5 \%$ for $P$. roseopurpureum and $9.2 \%$ for $A$. fumigatus. When both $\mathrm{C}$ and $\mathrm{N}$ sources were present, results were $40.0 \%$ for $F$. solani, $24.4 \%$ for $P$. roseopurpureum and $31.1 \%$ for A. fumigatus.

- For the soil HA, decolorization percentage was only given for $F$. solani. It was $0.0 \%$ when HA was supplied as the sole source of $\mathrm{C}, \mathrm{N}$ or $\mathrm{C}+\mathrm{N}$. When there were $\mathrm{C}$ and $\mathrm{N}$ sources, decolorization was of $18 \%$.

- Percentages of decolorization were measured as in Mathur and Paul (1967).

- When HA was the sole source of C, they were $8.9 \%$ for Aspergillus sp. from Bangalore, $11.6 \%$ for Aspergillus sp. from Calcuta and for Aspergillus sp. from Ranchi, $30.2 \%$ for A. awamori, $25.0 \%$ for $H$. insolens, $14.6 \%$ for P. fusisproms, $27.6 \%$ for Penicillium sp., $22.4 \%$ for $T$. spiralis and $19.8 \%$ for $T$. viride. When $\mathrm{HA}$ was the sole source of $\mathrm{N}$, they were $3.0 \%$ for Aspergillus sp. from Bangalore and Aspergillus sp. from Calcuta, 19.8\% for A. awamori, $0.0 \%$ for Aspergillus sp. from Ranchi, $17.2 \%$ for $H$. insolens, $0.3 \%$ for P. fusisproms, $22.4 \%$ for Penicillium sp., $6.0 \%$ for T. spiralis and $11.6 \%$ for $T$. viride. When HA was the sole source of both $\mathrm{C}$ and $\mathrm{N}$, they were $11.2 \%$ for Aspergillus sp. from Bangalore, $11.6 \%$ for Aspergillus sp. from Calcuta, 27.6\% for A. awamori, $0.9 \%$ for Aspergillus sp. from Ranchi, $22.4 \%$ for $H$. insolens, $17.2 \%$ for $P$. fusisproms and $T$. viride, and $25.0 \%$ for Penicillium sp. and T. spiralis. 


\begin{tabular}{|c|c|c|}
\hline Autor & Fungi, medium and experimental conditions & Comments and results \\
\hline $\begin{array}{l}\text { Haider and } \\
\text { Martin (1988) }\end{array}$ & $\begin{array}{l}\text { - }{ }^{14} \mathrm{C} \text {-labelled HA from an Alfisol previously mixed with } \\
{ }^{14} \mathrm{C} \text {-wheat straw. } \\
\text { - } \quad \text { Phanerochaete chrysosporium ATCC } 32629 \\
\text { - } 200 \text {-mL Erlenmeyer flasks with } 50 \mathrm{~mL} \text { liquid medium, } \\
\text { containing the mineral salts and vitamins of Kirk et al. } \\
\text { (1978), } 0.56 \mathrm{mmol} / \mathrm{L} \mathrm{D-glucose} \text { as carbon source, } \\
\text { variable amounts of } \mathrm{NH}_{4} \mathrm{NO}_{3} \text { and L-asparagine as } \\
\text { nitrogen sources and variable amount of HA, inoculated } \\
\text { with spores and held at } 35^{\circ} \mathrm{C} \text { for } 18 \text { days. }\end{array}$ & $\begin{array}{l}\text { - Three concentrations of } \mathrm{HA}(100,200 \mathrm{and} 400 \mathrm{mg} / \mathrm{L}) \text { were combined with } \\
\text { three concentrations of nitrogen }\left(0.6 \mathrm{mmol} / \mathrm{L} \mathrm{NH} \mathrm{NO}_{3}+0.6 \mathrm{mmol} / \mathrm{L} \mathrm{L}-\right. \\
\text { asparagine, } 3 \mathrm{mmol} / \mathrm{L} \mathrm{NH}_{4} \mathrm{NO}_{3}+3 \mathrm{mmol} / \mathrm{L} \mathrm{L} \text {-asparagine and } 6 \mathrm{mmol} / \mathrm{L} \\
\left.\mathrm{NH}_{4} \mathrm{NO}_{3}+6 \mathrm{mmol} / \mathrm{L} \mathrm{L}-\text { asparagine}\right) \text {, obtaining a total number of nine } \\
\text { experimental conditions. } \\
\text { - The percentage of } \mathrm{HA} \text { converted into }{ }^{14} \mathrm{CO}_{2} \text { increased with the incubation } \\
\text { time, but it was not considerably affected by the initial concentration of } \\
\mathrm{HA} \text {, only by that of the nitrogen source. After } 18 \text { days it was of } 33-35 \% \\
\text { for } 0.6 \mathrm{mmol} / \mathrm{L} \text { of each nitrogenous compound, } 18-19 \% \text { for } 3 \mathrm{mmol} / \mathrm{L} \text { and } \\
15-17 \% \text { for } 6 \mathrm{mmol} / \mathrm{L} \text {. }\end{array}$ \\
\hline $\begin{array}{l}\text { Haider and } \\
\text { Martin (1988) }\end{array}$ & $\begin{array}{l}\text { - HA-like synthetic polymers prepared from a mixture of } \\
\text { several substances with one }{ }^{14} \mathrm{C} \text {-labelled compound } \\
\text { (catechol, 4-chlorocatechol, } 4,5 \text {-dichlorocatechol, } \\
\text { ferulate, aniline, 4-chloroaniline or protein hydrolysate) } \\
\text { - Phanerochaete chrysosporium ATCC } 32629 \\
\text { - } 200 \text {-mL Erlenmeyer flasks with } 50 \mathrm{~mL} \text { liquid medium, } \\
\text { containing the mineral salts and vitamins of Kirk et al. } \\
(1978), 0.56 \mathrm{mmol} / \mathrm{L} \mathrm{D-glucose} \text { as carbon source, } 0.6 \\
\text { mmol/L } \mathrm{NH}_{4} \mathrm{NO}_{3} \text { and } 0.6 \mathrm{mmol} / \mathrm{L} \mathrm{L-asparagine} \mathrm{as} \\
\text { nitrogen sources (or the double, } 1.2 \mathrm{mmol} / \mathrm{L} \text { of each } \\
\text { nitrogenous compound) and } 100 \mathrm{mg} / \mathrm{L} \mathrm{HA} \text {, inoculated } \\
\text { with spores and held at } 35^{\circ} \mathrm{C} \text { for } 18 \text { days. }\end{array}$ & $\begin{array}{l}\text { - The chlorinated aromatic moieties were biodegradation intermediates of } \\
\text { herbicides and insecticides, which were known to be immobilized in soil by } \\
\text { binding to the humus matrix. The main objective of the experiment was to } \\
\text { determine if the fungus was able of mineralizing them as well as the non- } \\
\text { chlorinated ones, which were known to be units of the HA. } \\
\text { - The percentage of } \mathrm{HA} \text { converted into }{ }^{14} \mathrm{CO}_{2} \text { after } 18 \text { days in a medium of } \\
0.6 \mathrm{mmol} / \mathrm{L} \mathrm{NH}_{4} \mathrm{NO}_{3} \text { and } 0.6 \mathrm{mmol} / \mathrm{L} \mathrm{L} \text {-asparagine was of } 55.9 \% \text { for } \\
\text { catechol, } 38 \% \text { for } 4 \text {-chlorocatechol, } 45.7 \% \text { for } 4,5 \text {-dichlorocatechol, } 54.0 \% \\
\text { for ferulate, } 17.5 \% \text { for aniline, } 2.4 \% \text { for } 4 \text {-chloroaniline and } 24.7 \% \text { for } \\
\text { protein hydrolysate. } \\
\text { - If the nitrogen source concentration was doubled, the mineralization was } \\
\text { inhibited during the first } 5 \text { to } 10 \text { days, but after } 18 \text { days, the results were } \\
\text { very close to those with } 0.6 \mathrm{mmol} / \mathrm{L} \text { of each nitrogenous compound. }\end{array}$ \\
\hline
\end{tabular}




\begin{tabular}{|c|c|c|}
\hline Autor & Fungi, medium and experimental conditions & Comments and results \\
\hline $\begin{array}{l}\text { Blondeau } \\
\text { (1989) }\end{array}$ & $\begin{array}{l}\text { - Natural HA, extracted from a forest soil, with a modal } \\
\text { mass of } 23 \mathrm{kDa} \text {. } \\
\text { White-rot fungus Phanerochaete chrysosporium, strains } \\
\text { DSM } 1556 \text { and BKM-F } 1767 \\
\text { - Aerobic batch cultures in serum flasks of } 500 \mathrm{~mL} \text { with } \\
\text { cotton stoppers. Each flask contained } 50 \mathrm{~mL} \text { of a } \\
\text { sterilized aqueous medium which consisted of } 0.05 \% \\
\mathrm{HA}, 2 \mathrm{mg} / \mathrm{L} \text { thiamine, } 0.6 \mathrm{mmol} / \mathrm{L} \mathrm{NH}_{4} \mathrm{NO}_{3} \text { and } 0.6 \\
\text { mmol/L L-asparagine, buffered to } \mathrm{pH} 4.5 \text { with } 20 \\
\text { mmol/L sodium tartrate. } 56 \mathrm{mmol} / \mathrm{L} \text { glucose were } \\
\text { incorporated in some assays. Inoculation was performed } \\
\text { with conidial suspensions to obtain } 20 \times 10^{6} \text { spores per } \\
\text { flask. Cultures were incubated at } 35^{\circ} \mathrm{C} \text { for } 18 \text { days. }\end{array}$ & $\begin{array}{l}\text { - Without glucose, fungal growth (assessed by the weight of mycelium after } \\
\text { drying at } 105^{\circ} \mathrm{C} \text { ) and decolorization (evaluated by absorbance at } 350 \mathrm{~nm} \text { ) } \\
\text { were not seen. } \\
\text { - With glucose, the growth of the two strains was similar ( } 40 \mathrm{mg} \text { at day } 2,80 \\
\text { mg at day } 4,110 \mathrm{mg} \text { at day } 9 \text { and } 165 \mathrm{mg} \text { at days } 16-18) \text {, but } \\
\text { decolorization was only seen with the strain BKM-F } 1767 \text { ( } 2 \% \text { at day } 4 \text {, } \\
15 \% \text { at day } 4,57 \% \text { at day } 14 \text { and } 61 \% \text { at day } 18 \text { ). In this regard, no LiP } \\
\text { activity of the DSM } 1556 \text { strain was observed, whereas the BKM-F } 1767 \\
\text { one exhibited significant LiP activity. } \\
\text { - LiP activity of the strain BKM-F } 1767 \text { was also measured in a medium } \\
\text { without HA, finding that it was higher than that in the medium with HA. } \\
\text { - None is said about the HA adsorbed by the fungal hyphae. } \\
\text { Gel filtration chromatography profiles showed a reduction of HA molecular } \\
\text { weight after incubation for } 15 \text { days with strain BKM-F } 1767 \text {. The modal } \\
\text { mass was reduced to } 12 \mathrm{kDa} \text {. The size changes were particularly evident in } \\
\text { the high-molecular weight range (50 - } 500 \mathrm{kDa} \text { ). However, no } \\
\text { accumulation of low-molecular-weight compounds was noticed }\end{array}$ \\
\hline
\end{tabular}




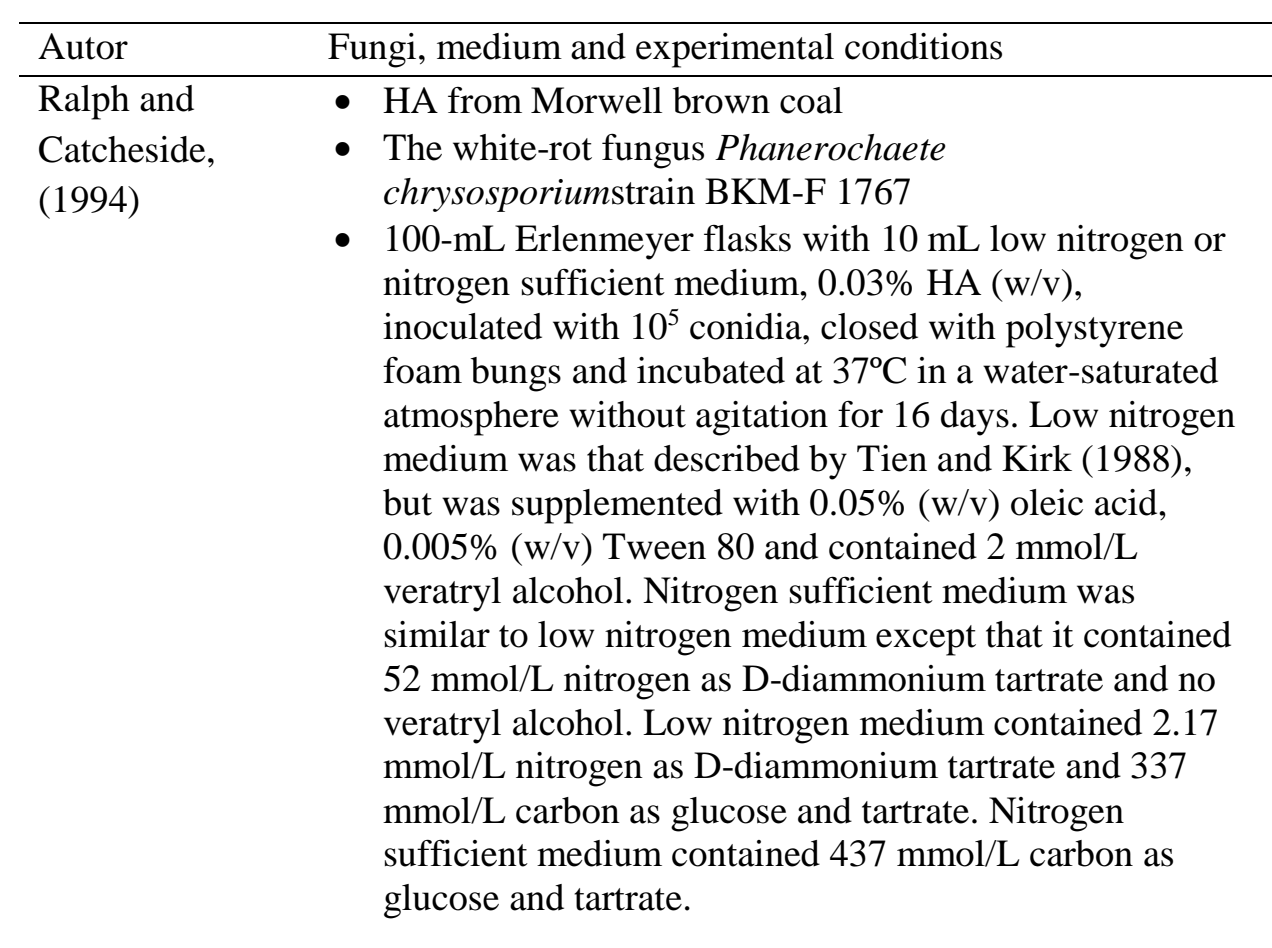

Comments and results

- Reduction of the absorbance at $400 \mathrm{~nm}$ was of $40 \%$ at day 4 in the nitrogen sufficient medium and of $84 \%$ at day 5 in the low nitrogen medium. Thereafter, and within the experimental error, there was not considerable decolorization. Recovery of the adsorbed HA probed that all the bleaching in the nitrogen sufficient medium was due to bisorption, but that this phenomenon was negligible in the low nitrogen medium.

- Gel permeation chromatography for the low nitrogen medium indicated that the modal mass slightly increased from 65 to $70 \mathrm{kDa}$ in the first day of incubation, remained roughly constant until day 5 and then decreased, reaching a value of $32 \mathrm{kDa}$ at day 16 (See Figure $1 \mathrm{~b}$ ). For the sufficient nitrogen medium, the modal mass increased from 65 to 76 between days 0 and 4 , remained constant until day 8 , then decreased to $61 \mathrm{kDa}$ at day 12 and increased to $67 \mathrm{kDa}$ at day 16 , but these changes were attributed to experimental error.

- Cell dry weight went through a maximum at 3-4 days and tended to a plateau at 16 days. Maxima were of $47 \mathrm{mg}$ in the sufficient nitrogen medium and of $21 \mathrm{mg}$ in the low nitrogen medium. Plateaux were of 23.5 $\mathrm{mg}$ in the nitrogen sufficient medium and of $16 \mathrm{mg}$ in the low nitrogen medium.

- Glucose was consumed faster in the nitrogen sufficient medium than in the low nitrogen medium.

- LiP activity in the low nitrogen medium was 0 on day 5 , peaked at $83 \mathrm{U} / \mathrm{L}$ on day 12 and reached a value around 30 U/L after 15 days. LiP activity was not detected in nitrogen sufficient médium. MnP activities were zero below 2 days and above 14 days, but went through maxima of $140 \mathrm{U} / \mathrm{L}$ at 4 days in the low nitrogen medium and of $95 \mathrm{U} / \mathrm{L}$ at 12 days in the sufficient nitrogen medium. Comparison with enzyme activities in the same media without HA revealed that HA considerably inhibited the activities of both LiP and MnP, and that in the low nitrogen medium, it changed the time at which the maximum of LiP appeared. 


\begin{tabular}{|c|c|c|}
\hline Autor & Fungi, medium and experimental conditions & Comments and results \\
\hline $\begin{array}{l}\text { Willmann and } \\
\text { Fakoussa } \\
\text { (1997) }\end{array}$ & $\begin{array}{l}\text { - HA from german lignite, with } 40.3 \% \mathrm{C}, 4 \% \mathrm{H}, 5.1 \% \mathrm{~N} \text {, } \\
24.9 \% \mathrm{O} \text { and } 25 \% \text { ash. } \\
\text { - Fungal strain RBS } 1 \mathrm{k} \text {, a haploid basidiomycete isolated } \\
\text { from an open-cast mining region (Cologne), probably } \\
\text { belonging to the Aphyllophorales or Agaricales } \\
\text { - } 250-\mathrm{mL} \text { conical flasks with } 80 \mathrm{~mL} \text { medium and an } \\
\text { unknown amount of HA, adjusted to pH 4.3, inoculated } \\
\text { with a piece of fungal mycelium from malt-extract agar } \\
\text { (0.5×0.5 cm) and incubated without shaking for } 25 \text { days. } \\
\text { The basal solution contained } 200 \mathrm{mg} / \mathrm{L} \mathrm{KH}_{2} \mathrm{PO}_{4}, 50\end{array}$ & $\begin{array}{l}\text { - In the mineral salt medium, the carbon sources were galactose, acetate, } \\
\text { glutamate, glucose and glycerine. For the two last ones, decolorizations (as } \\
\text { decrease of absorbances at } 420 \mathrm{~nm} \text { ) were of } 82 \% \text {, whereas they were } \\
\text { around } 10 \% \text { for the three first ones. } \\
\text { - In principle, these bleachings include both biodegradation and adsorption. } \\
\text { The authors affirmed that the mycelia became dark-coloured at the } \\
\text { beginning of the experiment, but that after a few days, they were bright } \\
\text { again. Howeber, it is not clear if this statement refers only to the media with } \\
\text { glucose and glycerine, or to all. }\end{array}$ \\
\hline
\end{tabular}

$\mathrm{mg} / \mathrm{L} \mathrm{MgSO}{ }_{4} \cdot 7 \mathrm{H}_{2} \mathrm{O}, 10 \mathrm{mg} / \mathrm{L} \mathrm{CaCl}_{2}, 20 \mathrm{mmol} / \mathrm{L}$ carbon source, $220 \mathrm{mg} / \mathrm{L}$ ammonium tartrate, $1 \mathrm{mg} / \mathrm{L}$ thiamine, $1.46 \mathrm{~g} / \mathrm{L}$ sodium dimethylsuccinate, $0.5 \mathrm{~g} / \mathrm{L}$ Tween 80 ; $5 \mathrm{~mL}$ trace elements and $0.5 \mathrm{~mL}$ vitamin solution. The composition of the trace elements was $3.0 \mathrm{~g} / \mathrm{L}$

$\mathrm{MgSO}_{4} \cdot 7 \mathrm{H}_{2} \mathrm{O}, 0.5 \mathrm{~g} / \mathrm{L} \mathrm{MnSO} 4 \cdot \mathrm{H}_{2} \mathrm{O}, 1.0 \mathrm{~g} / \mathrm{L} \mathrm{NaCl}, 100$ $\mathrm{mg} / \mathrm{L} \mathrm{FeSO}_{4} \cdot 7 \mathrm{H}_{2} \mathrm{O}, 100 \mathrm{mg} / \mathrm{L} \mathrm{CoSO}_{4}, 82 \mathrm{mg} / \mathrm{L} \mathrm{CaCl}_{2}$, $100 \mathrm{mg} / \mathrm{L} \mathrm{ZnCl}_{2}, 10 \mathrm{mg} / \mathrm{L} \mathrm{CuSO}_{4} \cdot 5 \mathrm{H}_{2} \mathrm{O}, 10 \mathrm{mg} / \mathrm{L}$ $\mathrm{AlCl}_{3}, 10 \mathrm{mg} / \mathrm{L} \mathrm{H}_{3} \mathrm{BO}_{3}$ and $10 \mathrm{mg} / \mathrm{L} \mathrm{NaMoO}_{4}$, whereas the vitamin solution consisted of $2 \mathrm{mg} / \mathrm{L}$ biotin, $2 \mathrm{mg} / \mathrm{L}$ folic acid, $5 \mathrm{mg} / \mathrm{L}$ thiamine hydrochloride, $5 \mathrm{mg} / \mathrm{L}$

riboflavin, $10 \mathrm{mg} / \mathrm{L}$ pyridoxine hydrochloride, $0.1 \mathrm{mg} / \mathrm{L}$ cyanocobalamine, $5 \mathrm{mg} / \mathrm{L}$ nicotinic acid, $5 \mathrm{mg} / \mathrm{L}$

calcium DL-pantothenate and $5 \mathrm{mg} / \mathrm{L} p$-aminobenzoic acid. 


\begin{tabular}{|c|c|c|}
\hline Autor & Fungi, medium and experimental conditions & Comments and results \\
\hline Fakoussa and & - HA from lignite & - Decolorizations at $\mathrm{C} / \mathrm{N}$ ratios of $46,68,72$ and 76 were $41,50,53.1$ and \\
\hline \multirow[t]{5}{*}{ Frost (1999) } & - Trametes versicolor DSM 3086 & $53.4 \%$, respectively. These values include both biosorption and \\
\hline & - Presumably, standing flask cultures with malt extract & biodegradation. \\
\hline & medium diluted to $1 / 5$ and an unspecified $\mathrm{HA}$ & - Activities of the dominating enzyme (Lac) were measured: at $\mathrm{C} / \mathrm{N}$ ratios of \\
\hline & $\begin{array}{l}\text { concentration around } 0.5-1.2 \mathrm{~g} / \mathrm{L} \mathrm{HA} \text { in an incubator } \\
\text { at } 30^{\circ} \mathrm{C} \text { and an atmosphere of } 40 \mathrm{vol} \% \text { oxygen for } 7\end{array}$ & $\begin{array}{l}46,68,72 \text { and } 76 \text { were } 640,425,360 \text { and } 339 \mathrm{U} / \mathrm{L} \text {, respectively. It is not } \\
\text { specified if these activities were averaged or those at the maximum. }\end{array}$ \\
\hline & $\begin{array}{l}\text { days. The } \mathrm{C} / \mathrm{N} \text { ratio of the medium (68) was varied } \\
\text { between } 46 \text { and } 76 \text { with dextrin and ammonium nitrate. }\end{array}$ & \\
\hline
\end{tabular}

Fakoussa and

Frost (1999)
- HA from lignite

- Trametes versicolor DSM 3086

- Standing cultures in Petri dishes with $25 \mathrm{~mL}$ medium and $0.05 \% \mathrm{HA}$ in an incubator at $30^{\circ} \mathrm{C}, 90 \%$ relative humidity and $40 \mathrm{vol} \%$ oxygen. Three media were compared: diluted malt extract, mineral salts and peptone. The mineral salt medium was supplied with different sources of C (glucose, galactose, glycerol, dextrin and sucrose) and $\mathrm{N}$ (sodium nitrate, ammonium nitrate and ammonium sulfate).
- Decolorization in the mineral salt medium followed the decreasing order: glycerol $>$ sucrose $>$ glucose $>\left(\mathrm{NH}_{4}\right)_{2} \mathrm{SO}_{4}>\mathrm{NH}_{4} \mathrm{NO}_{3}>$ dextrin $>\mathrm{NaNO}_{3} \geq$ galactose.

- Decolorizations in diluted malt and in peptone were the same than in the mineral salt medium with glycerol and dextrin, respectively.

- Decolorization in yeast extract was between that in peptone and that in the mineral medium with $\mathrm{NH}_{4} \mathrm{NO}_{3}$

- These bleachings include both adsorption and biodegradation. 


\begin{tabular}{|c|c|c|}
\hline Autor & Fungi, medium and experimental conditions & Comments and results \\
\hline $\begin{array}{l}\text { Gramss et al., } \\
\text { (1999) }\end{array}$ & 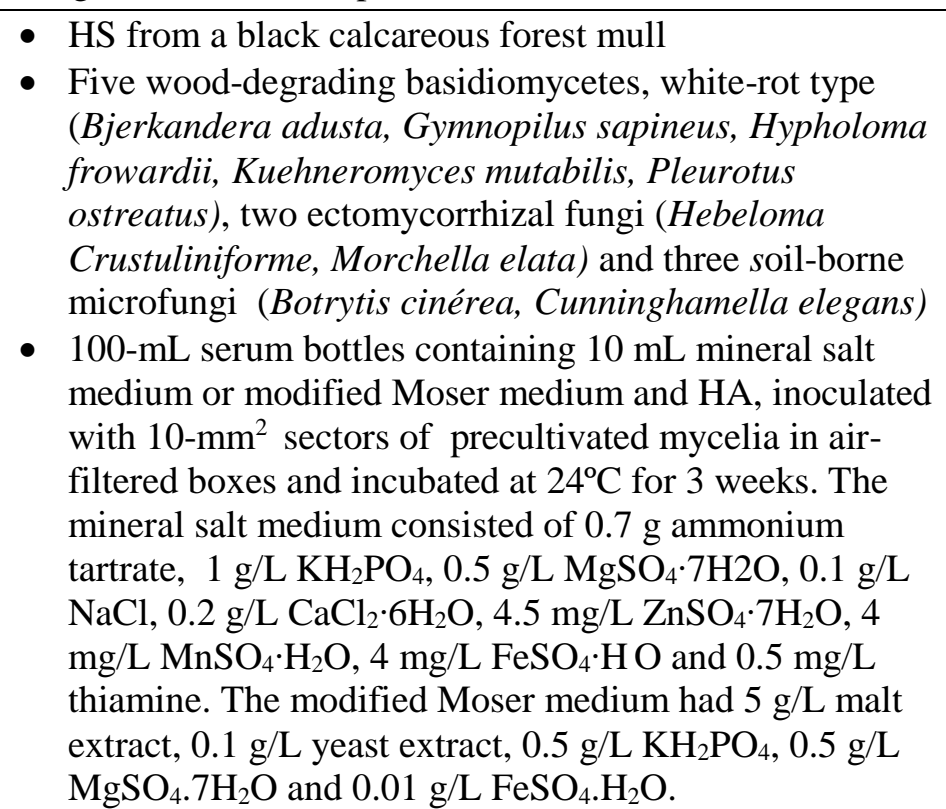 & 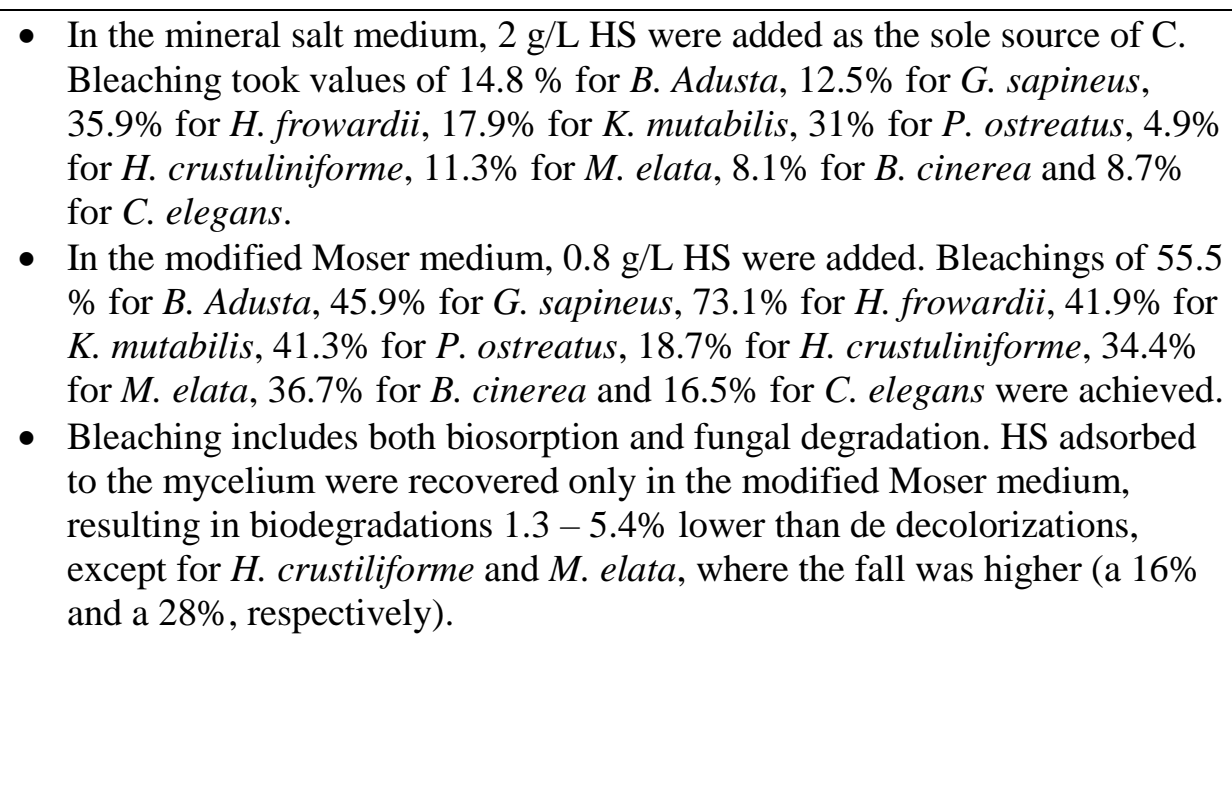 \\
\hline
\end{tabular}




\begin{tabular}{|c|c|}
\hline Autor & Fungi, medium and experimental conditions \\
\hline $\begin{array}{l}\text { Koukol et al. } \\
(2004)\end{array}$ & $\begin{array}{l}\text { - } \mathrm{HA} \text { from the } \mathrm{O}_{\mathrm{f}} \text { horizon of a Ferro Humic Podzol in } \\
\text { spruce forest, } 50.1 \% \mathrm{C}, 3.3 \% \mathrm{H}, 2.6 \% \mathrm{~N}, 41.8 \% \mathrm{O} \text {, } \\
2.2 \% \text { ash and } 0.2 \% \mathrm{P}\end{array}$ \\
\hline
\end{tabular}
$2.2 \%$ ash and $0.2 \% \mathrm{P}$

- Saprotrophic ascomycete Chalara longipes strain CCF 3367

- Cotton-plugged 100-mL Erlenmeyer flasks with $50 \mathrm{~mL}$ of medium, consisted of $2 \mathrm{~g} / \mathrm{L} \mathrm{NH}_{4} \mathrm{NO}_{3}, 1 \mathrm{~g} / \mathrm{L} \mathrm{K}_{2} \mathrm{HPO}_{4}$, $0.5 \mathrm{~g} / \mathrm{L} \mathrm{MgSO}_{4} \cdot 7 \mathrm{H}_{2} \mathrm{O}, 0.5 \mathrm{~g} / \mathrm{L} \mathrm{KCl}, 0.01 \mathrm{~g} / \mathrm{L} \mathrm{FeCl}_{3}, 0.5$ $\mathrm{g} / \mathrm{L} \mathrm{HA}, \mathrm{pH} 6.5$ and $20 \mathrm{~g} / \mathrm{L}$ malt extract or $19 \mathrm{~g} / \mathrm{L}$ glucose, inoculated with $1 \mathrm{~mL}$ spores and blended mycelium suspension $\left(2 \times 10^{3} \mathrm{CFU} / \mathrm{mL}\right)$ and incubated in the dark at $25^{\circ} \mathrm{C}$ on a reciprocal shaker $(2 \mathrm{~Hz}$ ) for 21 days.
Comments and results

- Decolorization (as absorbance at $665 \mathrm{~nm}$ ) and fungal growth for the medium with malt extract were of $75 \%$ and $95 \mathrm{mg}$, respectively. For the medium with glucose, they were of $64 \%$ and $38 \mathrm{mg}$. None is said about the influence of HA adsorption by the cells in bleaching.

- The ratio between the absorbances at $465 \mathrm{~nm}$ and $665 \mathrm{~nm}$ (used as an estimation of the molar-mass changes in HA) was higher in the medium with yeast extract than in the medium with glucose.

- Gel permeation chromatography revealed a decrease of the peak corresponding to HA in both media. In the chromatograms of the medium with yeast extract, there also was a decrease of the peaks due to the yeast extract, because the fungus utilized it as feed. 


\begin{tabular}{|c|c|}
\hline Autor & Fungi, medium and experimental conditions \\
\hline $\begin{array}{l}\text { Řezáčová et al. } \\
\text { (2006) }\end{array}$ & $\begin{array}{l}\text { - HA and FA from an arable soil (clay-loam orthic } \\
\text { luvisol) in Prague. } \\
\text { - Soil microfungi Alternaria alternata, Clonostachys } \\
\text { rosea, Paecilomyces lilacinus and Phoma sp } \\
\text { - } 100 \text {-mL Erlenmeyer flasks with } 10 \mathrm{~mL} \text { FA or HA } \\
\text { solutions, inoculated with } 0.5 \mathrm{~mL} \text { of a homogenized } \\
\text { mycelial suspension of each microfungal species and } \\
\text { incubated for } 1 \text { month. The effect of adding } 0.5 \mathrm{~mL} \text { of } \\
\text { glucose solution }(200 \mathrm{mg} / \mathrm{L}) \text { was studied. }\end{array}$ \\
\hline
\end{tabular}

Comments and results

- For HA as sole carbon source, the absorbances at $280 \mathrm{~nm}$ (related to the amount of phenolics) and at $665 \mathrm{~nm}$ (related to decolorization) were decreased by the four fungi, whereas the ratio between the absorbances at $465 \mathrm{~nm}$ and at $665 \mathrm{~nm}$ (related to changes in the molecular mass of HA) were increased. $C$. rosea was the most effective in degrading HA, followed by $P$. lilacinus. None is said about the influence of HA adsorption by the cells in bleaching. The TOC of the solutions was not significant affected by the strains. Biomass growth (as dry mycelial weight) was of $26-27 \mathrm{mg}$ for P. lilacinus and Phoma sp. and of $33-34 \mathrm{mg}$ for the other two fungi.

- For FA as sole carbon source, the four fungal species did not change considerably the absorbance at $665 \mathrm{~nm}$ nor the TOC of the solution.

Absorbance at $280 \mathrm{~nm}$ was significantly reduced only by A. alternata ($9.1 \%)$, and the ratio of absorbances at 465 and $665 \mathrm{~nm}$ was considerably increased by A. alternata (+107\%) and Phoma sp. (+146\%) None is said about the influence of FA adsorption by the cells in bleaching. Dry

mycelial biomass determined after 1 month was too small to be evaluated.

- The effect of glucose was not significative, except in the the ratio of absorbances at 465 and $665 \mathrm{~nm}$ for HA. 


\begin{tabular}{|c|c|}
\hline Autor & Fungi, medium and experimental conditions \\
\hline $\begin{array}{l}\text { Grinhut et al. } \\
\text { (2011b) }\end{array}$ & $\begin{array}{l}\text { - } \mathrm{HA} \text { from composted biosolids } \\
\text { - White-rot fungus Trametes sp. } \mathrm{M} 23 \text { isolated from } \\
\text { composted biosolids and grown on potato-dextrose agar. } \\
\text { - } 250 \text {-mL Erlenmeyer flasks with } 50 \mathrm{~mL} \text { of low nitrogen } \\
\text { or high nitrogen medium, } 0 \text { or } 7 \mathrm{mg} / \mathrm{L} \mathrm{MnSO}_{4} \cdot \mathrm{H}_{2} \mathrm{O} \text { and } \\
0.4 \mathrm{~g} / \mathrm{L} \mathrm{HA} \text {, inoculated with } 5 \text { plugs of potato-dextrose } \\
\text { agar }(5 \mathrm{~mm} \text { diameter) and incubated in a rotary shaker } \\
\text { at } 100 \mathrm{rpm} \text { and } 32^{\circ} \mathrm{C} \text { for } 17 \text { days. Both media contained } \\
10 \mathrm{~g} / \mathrm{L} \mathrm{glucose}, 0.18 \mathrm{~g} / \mathrm{L} \mathrm{L}-\text { phenylalanine, } 1 \mathrm{~g} / \mathrm{L} \\
\mathrm{KH}_{2} \mathrm{PO}_{4}, 0.5 \mathrm{~g} / \mathrm{L} \mathrm{KCl}, 0.5 \mathrm{~g} / \mathrm{L} \mathrm{MgSO}_{4} \cdot 7 \mathrm{H}_{2} \mathrm{O}, 0.05 \mathrm{~g} / \mathrm{L} \\
\mathrm{Ca}\left(\mathrm{NO}_{3}\right)_{2} \cdot 4 \mathrm{H}_{2} \mathrm{O}, 0.01 \mathrm{~g} / \mathrm{L} \mathrm{FeSO} \mathrm{Fe}_{4} \cdot 7 \mathrm{H}_{2} \mathrm{O}, 2 \mathrm{mg} / \mathrm{L} \mathrm{ZnNO} \text {, } \\
3 \mathrm{mg} / \mathrm{L} \mathrm{CuSO} \mathrm{CH}_{2} \cdot 5 \text {, and } 0.01 \mathrm{mg} / \mathrm{L} \text { thiamin, but the } \\
\text { high nitrogen medium included } 2.1 \mathrm{~g} / \mathrm{L} \mathrm{L-asparagine} \\
\text { and the low nitrogen one, } 0.3 \mathrm{~g} / \mathrm{L} \text {. }\end{array}$ \\
\hline
\end{tabular}

Comments and results

- In the high nitrogen medium with Mn(II), there was no bleaching (reduction of absorbance at $465 \mathrm{~nm}$ ). MnP activities went through a maximum of $300 \mathrm{U} / \mathrm{L}$ at day 7 and then decreased to around $30 \mathrm{U} / \mathrm{L}$ at day 17 , whereas Lac activity went through a maximum of $2450 \mathrm{U} / \mathrm{L}$ at day 14 and took a value of $1850 \mathrm{U} / \mathrm{L}$ after 17 days. When $\mathrm{Mn}(\mathrm{II})$ was absent, there was no bleaching, MnP activities decreased 7 times and Lac activities slightly increased (and did not went through a maximum).

- In the low nitrogen medium with $\mathrm{Mn}(\mathrm{II})$, a decolorization of $63 \%$ was achieved after 7 days, and then, remained constant. MnP activites went through a maxium of $300 \mathrm{U} / \mathrm{L}$ at day 7 , fell to $155 \mathrm{U} / \mathrm{L}$ at day 10 and remained roughly constant. Lac was almost negligible. In absence of $\mathrm{Mn}(\mathrm{II})$, a decolorization of $61 \%$ was reached at day 14 and thereafter, and the activities of both MnP and Lac were below $25 \mathrm{U} / \mathrm{L}$.

- Glucose was exhausted after 7 days in the high nitrogen medium, and after 14 days in the low nitrogen medium. Its consumption (and therefore, fungal growth) was not affected by the presence or absence of $\mathrm{Mn}$ (II).

- MnP and Lac activities were considerably different when measured in media without HA (except Lac in the low nitrogen medium, which was similar). LiP was not detected in any case.

- None is said about the influence of HA biosorption in the absorbance reduction. 


\begin{tabular}{lr}
\hline Autor & Fungi, medium and experimental conditions \\
\hline Zahmatkesh et & $\bullet$ Coal HA, containing a $20 \%$ small molecules $(<0.5 \mathrm{kDa})$, \\
al. (2016) & a $26 \%$ medium-sized compounds $(0.5-1 \mathrm{kDa})$ and a
\end{tabular}

al. (2016)

a $26 \%$ medium-sized compounds $(0.5-1 \mathrm{kDa})$ and a $54 \%$ large substances $(1-6.5 \mathrm{kDa})$.

- White-rot fungi Pleurotus sajor-caju MES03464, Pleurotus ostreatus MES00036, Trametes versicolor DSMZ 3086 and Phanerochaete chrysosporium DSMZ 1556

- 500-mL flasks containing $150 \mathrm{~mL}$ low nitrogen or nitrogen sufficient medium and $400 \mathrm{mg} / \mathrm{L} \mathrm{HA}$,

inoculated with five pieces of fungal agar, closed with cotton stoppers and incubated at $26^{\circ} \mathrm{C}$ and $150 \mathrm{rpm}$ for 18 days. Both media contained the same basal solution, minerals and vitamins than Kirk et al. (1978), sodium phthalate buffer (10 mmol/L, pH 4.5), glucose as carbon source $(56 \mathrm{mmol} / \mathrm{L})$ and ammonium tartrate as nitrogen source $(2 \mathrm{mmol} / \mathrm{L}$ in the nitrogen limited medium and $20 \mathrm{mmol} / \mathrm{L}$ in the nitrogen sufficient one)
Comments and results

- In the nitrogen sufficient medium, decolorizations (reduction of the chromatographic area) and biomass (weight after drying) were $45.5 \%$ and $270 \mathrm{mg}$ for $T$. versicolor, $74 \%$ and $300 \mathrm{mg}$ for $P$. chrysosporium, $34.2 \%$ and $283 \mathrm{mg}$ for P. sajor-caju and $47.9 \%$ and $230 \mathrm{mg}$ for P. ostreaus. When the HA adsorbed by mycelium were recovered, decolorizations fell to $32.2 \%$ for $T$. versicolor, $29.2 \%$ for $P$. chrysosporium, $27.8 \%$ for P. sajorcaju and $20 \%$ to $P$. ostreaus.

- In the nitrogen limited medium, decolorizations and biomass were $70.4 \%$ and $212 \mathrm{mg}$ for $T$. versicolor, $43.4 \%$ and $170 \mathrm{mg}$ for $P$. chrysosporium, $44.3 \%$ and $124 \mathrm{mg}$ for P. sajor-caju and $34.9 \%$ and $161 \mathrm{mg}$ for P. ostreaus. When the HA adsorbed by mycelium were recovered, decolorizations fell to $47.9 \%$ for $T$. versicolor, $33 \%$ for $P$. chrysosporium, $16.8 \%$ for $P$. sajorcaju and $12.6 \%$ to $P$. ostreaus.

- Size exclusion chromatography indicated an increase of the area due to small molecules, and a decrease of the areas of medium and large compounds. Proportions varied with fungi and media.

- There was a slight production of FA in almost all the systems, and it was observed that these substances had low affinity to biosorption by fungal hyphae.

- Enzyme activities were measured in media with and without HA. The humic compounds increase the Lac activities and decreased the MnP ones. LiP was not detected in any case. T. versicolor showed higher Lac and MnP activity when growing in nitrogen sufficien medium, but showed more HA removal in nitrogen limited medium. $P$. chrysosporium only generated $\mathrm{MnP}$, being its activities in the nitrogen sufficient medium higher than in the limited one (in accordance with the HA bleaching), but they are lower than those of the $T$. versicolor, which do not agree with the higher decolorization given by $P$. chrysosporium in the nitrogen sufficient medium. MnP activites of $P$. ostreaus (the only enzyme produced by it) were lower than those of $P$. sajor-caju in both media. 


\section{Table S2}

Influence of reaction medium and operational conditions in the fungal decolorization of humic compounds.

\section{Autor}

Mathur and

Paul (1966,

1967)

Mathur (1969)

- The same FA, fungus and Czapek-Dox broth fortified with $0.02 \%$ yeast than Mathur (1969) in Table S1 but with shaking.

Mathur (1970) - The same HA, FA, fungus and media than Mathur (1970) in Table S1 but with shaking

- The same HA, fungus and experimental conditions than Mathur and Paul $(1966,1967)$ in Table S1.
Comments and results

- The same than in Table S1: shaking improves the degradation considerably and inoculation with spores led to slightly lower decolorizations than inoculation with mycelium.

- No degradation of FA was observed.

- No degradation of FA or HA was detected. 


\begin{tabular}{|c|c|}
\hline Autor & Fungi, medium and experimental conditions \\
\hline $\begin{array}{l}\text { Dehorter and } \\
\text { Blondeau } \\
(1992)\end{array}$ & $\begin{array}{l}\text { - HA from forest soil, with } 50.2 \% \mathrm{C}, 5.3 \% \mathrm{H}, 3.5 \% \mathrm{~N} \\
\text { and } 3.8 \mathrm{meq} / \mathrm{g} \text { COOH (ash-free) } \\
\text { - White-rot fungi Phanerochaete chrysosporium } \\
\text { BKM-F1767 and Trametes versicolor DSM } 3086 \\
\text { - Roux flasks (which promote culture aeration) } \\
\text { containing } 50 \mathrm{~mL} \text { of basal medium (Kirk et al., } \\
\text { 1978) with } 56 \mathrm{mmol} / \mathrm{L} \text { glucose, } 1.2 \mathrm{mmol} / \mathrm{L} \mathrm{NH} \mathrm{HO}_{4} \mathrm{NO} \\
\text { and 0.05\% HA, buffered to } \mathrm{pH} 4.5 \mathrm{with} 20 \mathrm{mmol} / \mathrm{L} \\
\text { sodium tartrate. Sometimes, } 1 \mathrm{mmol} / \mathrm{L} \text { veratryl } \\
\text { alcohol was added. } P \text {. chrysosporium inocula } \\
\text { consisted of filtered conidial suspensions and T. } \\
\text { versicolor inocula consisted of mycelial } \\
\text { homogenates. Incubation took place for } 13 \text { days. }\end{array}$ \\
\hline
\end{tabular}

Comments and results

- For P. chrysosporium, the mycelium dry weight increased from $0 \mathrm{mg}$ before the incubation to $52 \mathrm{mg}$ at day 3 and to $115 \mathrm{mg}$ at day 13 . The decolorization (determined by absorbance at $350 \mathrm{~nm}$ ) rose from $20 \%$ at day 3 to $61 \%$ at day 5 , reaching the $73 \%$ at day 13 . $\mathrm{LiP}$ and $\mathrm{MnP}$ activities (estimated by absorbance changes instead of by molarity changes) went through maxima of $0.35 \mathrm{U} / \mathrm{mL}$ at day 4 and $0.45 \mathrm{U} / \mathrm{mL}$ at day 3 , respectively. If veratryl alcohol was added, the shape of the activity vs. time curves changed, and two maxima appeared: $0.43 \mathrm{U} / \mathrm{mL} \mathrm{LiP}$ and $0.6 \mathrm{U} / \mathrm{mL} \mathrm{MnP}$ at day 4 and $0.88 \mathrm{U} / \mathrm{mL} \mathrm{LiP}$ and $0.63 \mathrm{U} / \mathrm{mL} \mathrm{MnP}$ at day 11.

- For T. versicolor, the fungal growth was $30 \mathrm{mg}$ at day 3 and $53 \mathrm{mg}$ at day 13 , whereas decolorizations of $14 \%$ at day $3,50 \%$ at day 5 and $81 \%$ at day 13 were observed. LiP and MnP activities went through maxima of $0.40 \mathrm{U} / \mathrm{mL}$ at day 4 and $1.10 \mathrm{U} / \mathrm{mL}$ at day 3 , respectively. If veratryl alcohol was added, all activities are enhanced (the maximum activity of LiP became $1.1 \mathrm{U} / \mathrm{mL}$ at 5 days, and, although the maximum of MnP did not vary very much, MnP activities in days $4-13$ are higher than those without alcohol).

- Despite of the increase of LiP and MnP activities due to the alcohol, no significant change in the decolorization was observed.

- For T.versicolor, LiP and MnP activities in media without HA were almost zero. For $P$. chrysosporium, they were lower than those in media with HA.

- None is said about the HA adsorbed to the mycelia. 


\begin{tabular}{|c|c|c|}
\hline Autor & Fungi, medium and experimental conditions & Comments and results \\
\hline $\begin{array}{l}\text { Ralph et al. } \\
\text { (1996) }\end{array}$ & $\begin{array}{l}\text { - HA from Morwell brown coal, soluble between } \mathrm{pH} 3 \\
\text { and 6, with a modal mass around } 85 \mathrm{kDa} \text {. } \\
\text { The white-rot fungi Merulius tremellosus FPRL 13, } \\
\text { Perenniporia tephropora DFP 7904, Phanerochaete } \\
\text { chrysosporium ATCC } 24725 \text {, } \\
\text { - } 100 \text {-mL conical flasks filled with } 15-\mathrm{mL} \text { or } 10-\mathrm{mL} \\
\text { low nitrogen medium and } 0.045 \% \mathrm{HA} \text {, incubated } \\
\text { statically at } 28^{\circ} \mathrm{C} \text { for up to } 28 \text { days in a humidified } \\
\text { atmosphere to minimise evaporation. The medium } \\
\text { was a version of that of Tien and Kirk (1988), and } \\
\text { contained } 2.17 \text { mmol/L N as D-diammonium } \\
\text { tartrate, } 337 \text { mmol/L C as glucose and tartrate, } 2 \\
\text { mmol/L veratryl alcohol, } 0.05 \% \text { w/v oleic acid and } \\
0.005 \% \text { w/v Tween- } 80 \text { and was buffered at } \mathrm{pH} 4.2 \\
\text { with } 10 \mathrm{mmol} / \mathrm{L} 2,2-\text { dimethyl succinate. }\end{array}$ & 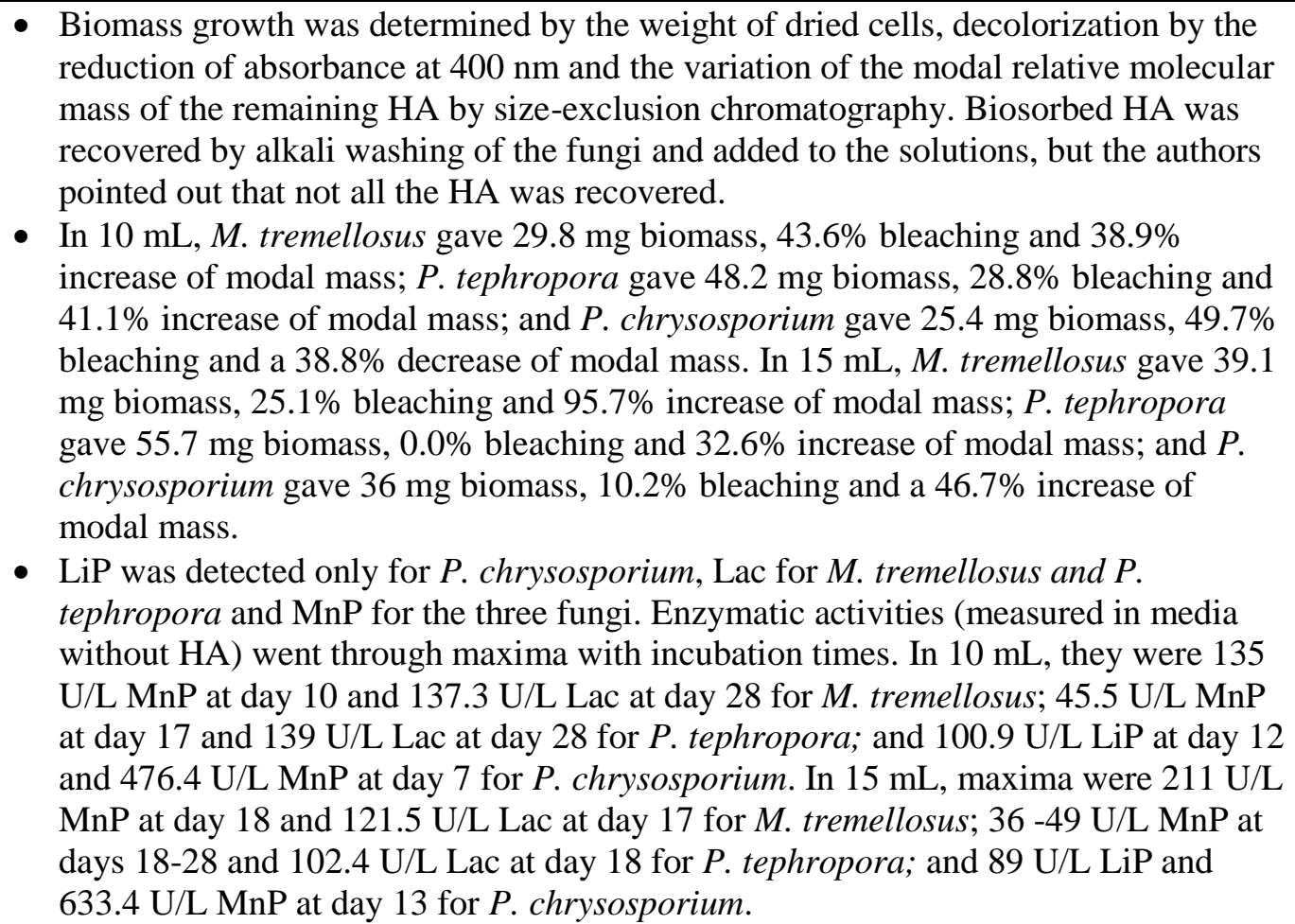 \\
\hline
\end{tabular}




\begin{tabular}{|c|c|c|}
\hline Autor & Fungi, medium and experimental conditions & Comments and results \\
\hline $\begin{array}{l}\text { Ralph and } \\
\text { Catcheside, } \\
\text { (1998a) }\end{array}$ & $\begin{array}{l}\text { - HA from Morwell brown coal, soluble in water } \\
\text { below pH } 6 \\
\text { - The white-rot fungus Phanerochaete chrysosporium } \\
\text { strain BKM-F } 1767 \\
\text { 100-mL Erlenmeyer flasks with } 10 \mathrm{~mL} \text { low nitrogen } \\
\text { medium, 0.03\% HA (w/v), buffered at pH } 4.2 \text { with } \\
20 \text { mmol/L potassium acetate, inoculated with } 10^{5} \\
\text { conidia, plugged with open-cell foam polyurethane } \\
\text { stoppers and incubated statically for } 20 \text { days at } 28 \text { or } \\
37^{\circ} \mathrm{C} \text { under air or hyperbaric oxygen. The medium } \\
\text { was the same than Tien and Kirk (Tien and Kirk, } \\
\text { 1988), but was supplemented with } 0.05 \% \text { (w/v) oleic } \\
\text { acid, 0.005\% (w/v) Tween } 80 \text { and occasionally } 2 \\
\text { mmol/L veratryl alcohol. }\end{array}$ & $\begin{array}{l}\text { - Bleaching was determined by absorbance at } 400 \mathrm{~nm} \text { after recovering the HA } \\
\text { adsorbed on the cells by alkali washing. Modal masses were measured by gel } \\
\text { permeation chromatography. } \\
\text { - At } 28^{\circ} \mathrm{C} \text {, hyperbaric oxygen and without veratryl alcohol, decolorization was of } 1 \% \\
\text { at day } 3,97 \% \text { at day } 15 \text { and } 95 \% \text { at day } 20 \text {. The modal mass of the remaining HA } \\
\text { fell a } 5 \% \text { after } 9 \text { days when compared with the initial mass and a } 48 \% \text { after } 20 \text { days. } \\
\text { - At the same conditions, but with veratryl alcohol, decolorization was of } 5 \% \text { at day } 3 \text {, } \\
47 \% \text { at day } 5 \text { and } 96 \% \text { at day } 20 \text {. The modal mass of the remaining HA decreased a } \\
3 \% \text { after } 6 \text { days and a } 57 \% \text { after } 20 \text { days. } \\
\text { - At } 28^{\circ} \mathrm{C} \text {, air and veratryl alcohol, decolorization was of } 2 \% \text { at day } 3 \text { and of } 45 \% \text { at } \\
\text { day } 20 \text {. The modal mass rose a } 15 \% \text { of the initial value at day } 9 \text {, but decreased to a } \\
9 \% \text { of this initial value at day } 20 \text {. } \\
\text { - At } 37^{\circ} \mathrm{C} \text {, hyperbaric oxygen and veratryl alcohol, decolorization was of } 5 \% \text { at day } 3 \text {, } \\
43 \% \text { at day } 5 \text { and } 68 \% \text { at day } 20 \text {. The modal apparent molecular mass of the } \\
\text { remaining HA fell a } 6 \% \text { after } 6 \text { days and a } 37.5 \% \text { after } 20 \text { days. } \\
\text { - At } 37^{\circ} \mathrm{C} \text {, air and veratryl alcohol, decolorization was of } 11 \% \text { at day } 3 \text { and of } 30 \% \text { at } \\
\text { day } 20 \text {. The modal apparent molecular mass of the remaining HA decreased a } 6 \% \\
\text { after } 3 \text { days, increased to a } 10 \% \text { after } 6 \text { days and only decreased considerably } \\
\text { between days } 15 \text { and } 20 \text {. } \\
\text { - LiP and MnP activities were also determined, but in media without HA. They went } \\
\text { through maxima at } 8 \text { - } 12 \text { days, except in the fifth case, where they peaked around } 5 \\
-7 \text { days. MnP activities were higher than those of LiP, especially in the third last } \\
\text { cases. Statistical analyses showed that the decline in absorbance correlated well with } \\
\text { the time-integrated LiP activity, whereas the modal mass variation was related with } \\
\text { the time-integrated MnP activity. }\end{array}$ \\
\hline
\end{tabular}




\begin{tabular}{lc}
\hline Autor & Fungi, medium and experimental conditions \\
\hline Ralph and & $\bullet$ HA from Morwell brown coal, soluble in water \\
Catcheside & below pH 6, with a modal mass (determined by gel \\
(1998b) & permeation chromatography) around 71 -73 kDa.
\end{tabular}

- The white-rot fungus Phanerochaete chrysosporium strain BKM-F 1767

- The low-nitrogen medium and the same conditions than Ralph and Catcheside (1994), but with 0, 10, 50 and $200 \mu \mathrm{mol} / \mathrm{L} \mathrm{Mn}$ (II) and incubation for 10 days under hyperbaric oxygen.

Claus and

Filip (1998)
- HA from groundwater (Fuhrberg, Germany), with $54.5 \% \mathrm{C}, 4.65 \% \mathrm{H}, 1.9 \% \mathrm{~N}$ and $39.05 \% \mathrm{O}$ (ash free), $12 \mu \mathrm{g} / \mathrm{mg}$ amino acids and $2.8 \mu \mathrm{g} / \mathrm{mg}$ carbohydrates.

- Cladosporium cladosporioides strain P8

- Autoclaved 250-mL Erlenmeyer flasks containing $100 \mathrm{~mL}$ of a synthetic culture broth ( $\mathrm{pH}$ 5.9), with $10 \mathrm{mg} / \mathrm{L} \mathrm{CuSO} \cdot 5 \mathrm{H}_{2} \mathrm{O}$,

- $12.25 \mathrm{~g} / \mathrm{L} \mathrm{KH} \mathrm{KHO}_{4}, 1.42 \mathrm{~g} / \mathrm{L} \mathrm{Na}_{2} \mathrm{HPO}_{4}, 1.7 \mathrm{~g} / \mathrm{L}$ Bacto yeast nitrogen base (Difco), $10 \mathrm{~g} / \mathrm{L}$ glucose, 1 $\mathrm{g} / \mathrm{L} \mathrm{NaNO}_{3}$ and $1 \mathrm{~g} / \mathrm{L}$ HA. They were inoculated with $0.1 \mathrm{~mL}$ of a spore suspension, and incubated at $25^{\circ} \mathrm{C}$ for up to 28 days either agitated $(100 \mathrm{rpm})$ or stationary.
Comments and results

- Decolorization (decrease of initial absorbance at $400 \mathrm{~nm}$ ) at day 4 was of 2.8, 10.3, 14.4 and $18.7 \%$ for $0,10,50$ and $200 \mu \mathrm{mol} / \mathrm{L} \mathrm{Mn}(\mathrm{II})$, respectively, and at day 10 , it was of $63.8,64.8,72.0$ and $73.6 \%$ for $0,10,50$ and $200 \mu \mathrm{mol} / \mathrm{L}$, respectively. In all the cases, the HA adsorbed on the mycelia were recovered by alkali washing and added to the solutions.

- Modal mass fell with reaction time, but the decrease only was considerable after 5 days. At day 10, masses were of $60 \mathrm{kDa}$ for $0 \mu \mathrm{mol} / \mathrm{L} \mathrm{Mn}(\mathrm{II}), 56 \mathrm{kDa}$ for $10 \mu \mathrm{mol} / \mathrm{L}$ $\mathrm{Mn}(\mathrm{II})$ and $46 \mathrm{kDa}$ for 50 and $200 \mu \mathrm{mol} / \mathrm{L} \mathrm{Mn}(\mathrm{II})$.

- Time-integrated activities of MnP increased with Mn content, whereas those of LiP went through a maximum at $10 \mu \mathrm{mol} / \mathrm{L} \mathrm{Mn}$ (II). For concentrations higher than that, time-integrated MnP activites were higher than those of LiP. Measurements in a HAfree media indicated that HA inhibited the activity of both enzymes.

- In shaken cultures, the amount of biomass increased to $2800 \mathrm{mg}$ at day 14 and then to $4000 \mathrm{mg}$ at day 28 , whereas absorbance at $465 \mathrm{~nm}$ decreased a $18 \%$ at day 14 and a $40 \%$ at day 28 . In stationary cultures, biomass rose to $2020 \mathrm{mg}$ at day 14 and then to $3370 \mathrm{mg}$ at day 28 , whereas absorbance fell a $15.3 \%$ at day 14 and a $28.2 \%$ at day 28. Shaking the fungal biomass with $\mathrm{NaHCO}_{3}$ indicated that around a $30 \%$ of the HA was adsorbed by the cells, but it is not clear in the paper if these figure was substracted to the aforementioned decolorizations.

- Activity of the ligninolytic enzymes, estimated by the degradation of an industrial dye, improved with aereation by agitation as well.

- At the end of the shaken experiment, the biodegraded HA contained $48.83 \% \mathrm{C}$, $4.82 \% \mathrm{H}, 2.88 \% \mathrm{~N}$ and $43.47 \% \mathrm{O}$ (ash free), $33 \mu \mathrm{g} / \mathrm{mg}$ amino acids and $4 \mu \mathrm{g} / \mathrm{mg}$ carbohydrates. Aromaticity was lower than in the original HA. 


\begin{tabular}{|c|c|c|}
\hline Autor & Fungi, medium and experimental conditions & Comments and results \\
\hline $\begin{array}{l}\text { Steffen et al. } \\
(2002)\end{array}$ & $\begin{array}{l}\text { - HA extracted from litter from a mixed pine-spruce } \\
\text { forest in Finland } \\
\text { - The soil-colonizing basidiomycete Collybia } \\
\text { dryophila } \mathrm{K} 209 \\
\text { - Stationary culture cultivation was carried out in } 1-\mathrm{L} \\
\text { Erlenmeyer flasks containing } 150 \mathrm{~mL} \text { of medium } \\
\left(10 \mathrm{~g} / \mathrm{L} \text { of glucose, } 2 \mathrm{~g} / \mathrm{L} \text { of } \mathrm{KH}_{2} \mathrm{PO}_{4}, 0.5 \mathrm{~g} / \mathrm{L} \text { of }\right. \\
\mathrm{MgSO}_{4} \cdot 7 \mathrm{H}_{2} \mathrm{O}, 0.1 \mathrm{~g} / \mathrm{L} \text { of } \mathrm{CaCl}_{2}, 0.5 \mathrm{~g} / \mathrm{L} \text { of } \\
\text { ammonium tartrate, } 2.2 \mathrm{~g} / \mathrm{L} \text { of } 2,2- \\
\text { dimethylsuccinate, } 0.1 \mathrm{~g} / \mathrm{L} \text { of yeast extract and } \mathrm{pH} \\
\text { adjusted to } 5.0) \text {. The concentration of } \mathrm{HA} \text { was of } \\
250 \mathrm{mg} / \mathrm{L} \text {. Certain cultures were supplemented with } \\
\mathrm{MnCl}_{2}(0.2 \text { mmol/L). Flasks were inoculated with } 10 \\
\text { agar plugs }(10 \mathrm{~mm} \text { in diameter) and incubated at } \\
20^{\circ} \mathrm{C} \text { in the dark for } 42 \text { days. }\end{array}$ & $\begin{array}{l}\text { - Without } \mathrm{MnCl}_{2} \text {, decolorization (as reduction of absorbance at } 450 \mathrm{~nm} \text { ), MnP and } \\
\mathrm{Lac} \text { activities were of } 60 \%, 43 \mathrm{U} / \mathrm{L} \text { and } 18 \mathrm{U} / \mathrm{L} \text {, respectively. In the presence of } \\
\mathrm{MnCl}_{2} \text {, decolorization, } \mathrm{MnP} \text { and } \mathrm{Lac} \text { activities were of } 82 \%, 102 \mathrm{U} / \mathrm{L} \text { and } 23 \mathrm{U} / \mathrm{L} \text {, } \\
\text { respectively. None is said about the biosorption of } \mathrm{HA} \text { in the cells. Both the } \\
\text { decolorization and the enzyme activities rose with incubation time, but the increase } \\
\text { rate was higher at the beginning of the reaction than at the end. } \\
\text { - Activities of both enzymes determined in a HA-free medium, were lower than those } \\
\text { in presence of the humic compound. } \\
\text { - Size exclusion chromatography revealed that } 60 \% \text { of the HA was degraded without } \\
\mathrm{MnCl}_{2} \text {, whereas } 75 \% \text { was degraded in presence of } \mathrm{MnCl}_{2} \text {. Molecular mass } \\
\text { distribution of residual HA was changed towards lower masses only in the presence } \\
\text { of manganese chloride (from } 2.5 \text { to } 1.5 \mathrm{kDa} \text { for the modal mass). The formation of } \\
\text { FA was also studied: FA had a modal mass around } 0.5 \mathrm{kDa} \text {, and the largest amount } \\
\text { of it was found in cultures supplemented with } \mathrm{Mn}(\mathrm{II})\end{array}$ \\
\hline $\begin{array}{l}\text { Steffen et al. } \\
(2002)\end{array}$ & $\begin{array}{l}\text { - }{ }^{14} \mathrm{C}-\text {-labeleded HA by spontaneous oxidative } \\
\text { polymerization of }{ }^{14} \mathrm{C} \text {-catechol } \\
\text { The soil-colonizing basdiomycete Collybia } \\
\text { dryophila } \mathrm{K} 209 \\
\text { - } 15 \mathrm{~mL} \text { of the same medium than Steffen et al. } \\
\text { (Steffen et al., 2002) in Table } \mathrm{S} 1 \text {, with } 12.8 \mathrm{mg} / \mathrm{L} \\
\mathrm{HA} \mathrm{dissolved} \mathrm{in} 0.1 \mathrm{NaOH} \text { and } 0 \text { or } 0.2 \mathrm{mmol} / \mathrm{L} \\
\mathrm{MnCl}_{2} \text {. Incubation was carried out at } 24^{\circ} \mathrm{C} \text { in the } \\
\text { dark. }\end{array}$ & $\begin{array}{l}\text { - In the absence of } \mathrm{Mn}(\mathrm{II}) \text {, the fungus mineralized } 18.9 \% \text { of the } \mathrm{HA} \text {, while } 35.3 \% \text { was } \\
\text { incorporated into the biomass or closely bound to the cell surface, and the release of } \\
{ }^{14} \mathrm{CO}_{2} \text { vs. incubation time was almost linear. } \\
\text { - Mineralization was faster at the beginning of the reaction that at the end. The } \\
\text { presence of } \mathrm{Mn}(\mathrm{II}) \text { caused a noticeable stimulation of }{ }^{14} \mathrm{CO}_{2} \text { production (an increase } \\
\text { of } 49.4 \%) \text {. } \\
\text { - In both the presence and absence of } \mathrm{Mn}(\mathrm{II}) \text {, only negligible amounts of }{ }^{14} \mathrm{C}-\text { labeled } \\
\text { volatile organic compounds were formed. }\end{array}$ \\
\hline $\begin{array}{l}\text { Grinhut et al. } \\
(2011 b)\end{array}$ & $\begin{array}{l}\text { - The same HA, fungus, media and experimental } \\
\text { conditions than Grinhut et al. (2011b) in Table S1. }\end{array}$ & $\begin{array}{l}\text { - The same than in Table } \mathrm{S} 1 \text { : the presence of } \mathrm{Mn}(\mathrm{II}) \text { increases the decolorization rate } \\
\text { in the low nitrogen medium, but does not improves very much the final bleaching. } \\
\text { The element also increases the activities of MnP in both nitrogen sufficient and } \\
\text { nitrogen limited medium, but slightly reduces the activities of Lac. }\end{array}$ \\
\hline
\end{tabular}




\begin{tabular}{|c|c|c|}
\hline Autor & Fungi, medium and experimental conditions & Comments and results \\
\hline $\begin{array}{l}\text { Zahmatkesh et } \\
\text { al. (2016) }\end{array}$ & $\begin{array}{l}\text { - Coal HA } \\
\text { - Trametes versicolor DSMZ } 3086 \\
\text { - } 100 \text {-mL flasks containing } 25 \mathrm{~mL} \text { low nitrogen or } \\
\text { nitrogen sufficient medium, fungal pellets ( } 8 \mathrm{~g} \text { wet } \\
\text { weight) and an unspecified concentration of HA } \\
\text { incubated for } 4 \text { days. Occasionally, } 1 \text { - } \\
\text { aminobenzotriazole, an inhibitor of cytochrome } \\
\text { P450 enzymes, was added. }\end{array}$ & $\begin{array}{l}\text { - In the nitrogen sufficient medium without inhibitor, decolorizations (absorbances at } \\
450 \mathrm{~nm} \text { ) were } 49,72 \text { and } 81 \% \text { after } 1,2 \text { and } 4 \text { days, respectively. With inhibitor, } \\
\text { they were of } 33 \% \text { at day } 1 \text {, of } 45 \% \text { at day } 2 \text { and of } 80 \% \text { at day } 4 \text {. } \\
\text { - In the nitrogen limited medium without inhibitor, decolorizations were } 52,78 \text { and } \\
84 \% \text { after } 1,2 \text { and } 4 \text { days, respectively. With inhibitor, they were of } 7 \% \text { at day } 1 \text {, of } \\
71 \% \text { at day } 2 \text { and of } 84 \% \text { at day } 4 \text {. } \\
\text { - The effect of the adsorbed HA is not referred, but since the authors devoted part of } \\
\text { its paper to this issue (see Table S1), it is likely that biosorption was somehow taker } \\
\text { into account. }\end{array}$ \\
\hline
\end{tabular}




\section{Table S3}

Influence of feed concentration in the fungal decolorization of humic compounds.

\begin{tabular}{ll}
\hline Autor & Fungi, medium and experimental conditions \\
\hline Mathur (1969) & - FA from the Bh horizon of Armadale soil \\
& - The white-rot fungus Poria subacida 17780 \\
& 200-mL Erlenmeyer flasks containing $25 \mathrm{~mL}$ \\
& Czapek-Dox broth fortified with $0.02 \%$ yeast \\
& extract at pH 5.0, with $0.05-1.0 \% \mathrm{FA}$, \\
& inoculated with 72-h cultures and incubated at \\
& $28^{\circ} \mathrm{C}$ without shaking for 24 or 46 days.
\end{tabular}

Comments and results

Haider and Martin (1988)

Petrovic et al

(1993)
- The same HA, fungus and experimental conditions than Haider and Martin (1988) in Table S1.

- HA from a commercial source and HA and FA from the uncultivated soil of a croatian wooded hill

- Mycelial pellets of the mold Trichoderma viride

- $100 \mathrm{~mL}$ of basal medium $\left(0.2 \mathrm{~g} / \mathrm{L} \mathrm{NH}_{4} \mathrm{NO}_{3}, 1\right.$ $\mathrm{g} / \mathrm{L} \mathrm{KH}_{2} \mathrm{PO}_{4}, 0.5 \mathrm{~g} / \mathrm{L} \mathrm{MgSO}_{4}, 0.5 \mathrm{~g} / \mathrm{L} \mathrm{KCl}$, $0.5 \mathrm{~g} / \mathrm{L}$ peptone and $0.002 \mathrm{~g} / \mathrm{L}$ thiamine) with two concentrations of soil HA (40 or 80 $\mathrm{mg} / \mathrm{L})$, soil FA (42.5 or $85 \mathrm{mg} / \mathrm{L})$ or commercial HA ( 25 or $50 \mathrm{mg} / \mathrm{L})$, inoculated with $1 \mathrm{~g}$ of mycelia (fresh weight) and incubated at $\mathrm{pH} 6$ and $25^{\circ} \mathrm{C}$ for 10 days
- Solutions with FA adsorbed on mycelia served as controls in color comparisons.

- Decolorizations (reduction of absorbances at $465 \mathrm{~nm}$ ) after 24 days for 0.05, 0.1, 0.2 and $0.4 \%$ FA were 45.3, 26, 0 and $0 \%$, respectively. After 46 days, they only were measured for 0.2 and $0.4 \% \mathrm{FA}$, being 32.9 and $13.8 \%$, respectively. For concentrations of $1 \% \mathrm{FA}$, there was no decolorization at any time.

- The same results than Haider and Martin (1988) in Table S1: for a given concentration of the $\mathrm{N}$ sources: the percentage of mineralized HA was not considerably affected by the initial concentration.

- Commercial HA: For $25 \mathrm{mg} / \mathrm{L}$, bleachings (evaluated by removal of COD) were $30.3 \%$ at $5 \mathrm{~h}, 53.4 \%$ at day $3,60.3 \%$ at day 6 and $63.4 \%$ at day 10 . For $50 \mathrm{mg} / \mathrm{L}$, they were $31.4 \%$ at 5 h, $32.8 \%$ at day $3,35.5 \%$ at day 6 and $40.3 \%$ at day 10 .

- Soil HA: For $40 \mathrm{mg} / \mathrm{L}$, decolorizations were $14.8 \%$ at 5 h, 31.6\% at day 3, $37.1 \%$ at day 6 and $39.9 \%$ at day 10 . For $80 \mathrm{mg} / \mathrm{L}$, they were $13.1 \%$ at $5 \mathrm{~h}$, $35.1 \%$ at day $3,36.1 \%$ at day 6 and $37.1 \%$ at day 10 .

- Soil FA: For $42.5 \mathrm{mg} / \mathrm{L}$, decolorizations were $11.9 \%$ at 5 h, $39.9 \%$ at days 3 and 6 , and $43.0 \%$ at day 10 . For $85 \mathrm{mg} / \mathrm{L}$, they were $8.9 \%$ at $5 \mathrm{~h}, 17.1 \%$ at day 3 , $20.1 \%$ at day 6 and $24.6 \%$ at day 10 .

- These results comprise both biosorption and fungal decomposition. Further experiments revealed that the removals of the first five hours were due to adsorption, whereas those thereafter were due to biodegradation. 


\begin{tabular}{|c|c|c|}
\hline Autor & Fungi, medium and experimental conditions & Comments and results \\
\hline $\begin{array}{l}\text { Willmann and } \\
\text { Fakoussa (1997) }\end{array}$ & $\begin{array}{l}\text { - HA from german lignite, with } 40.3 \% \mathrm{C}, 4 \% \\
\mathrm{H}, 5.1 \% \mathrm{~N}, 24.9 \% \mathrm{O} \text { and } 25 \% \text { ash. } \\
\text { - Fungal strain RBS } 1 \mathrm{k} \text {, a haploid } \\
\text { basidiomycete isolated from an open-cast } \\
\text { mining region (Cologne), probably belonging } \\
\text { to the Aphyllophorales or Agaricales } \\
\text { - } 250 \text {-mL conical flasks with diluted malt } \\
\text { extract and } 0.01-0.20 \% \mathrm{w} / \mathrm{v} \mathrm{HA} \text { at } 28^{\circ} \mathrm{C} \text { for } \\
\text { several days. }\end{array}$ & $\begin{array}{l}\text { - Decolorizations of 58, } 65 \text { and } 18 \% \text { were obtained for } 0.025,0.05 \text { and } 0.20 \% \\
\text { HA, respectively, for an unspecified incubation time. These values includes both } \\
\text { biodegradation and adsorption. } \\
\text { - MnP activities went through maxima with both incubation time and HA } \\
\text { concentration. These maxima were of } 59 \mathrm{U} / \mathrm{L} \text { at day } 6 \text { for } 0 \% \mathrm{HA}, 136 \mathrm{U} / \mathrm{L} \text { at } \\
\text { day } 7 \text { for } 0.01 \% \mathrm{HA}, 121 \mathrm{U} / \mathrm{L} \text { at day } 7 \text { for } 0.025 \% \mathrm{HA}, 173 \mathrm{U} / \mathrm{L} \text { at day } 6 \text { for } \\
0.05 \% \mathrm{HA}, 523 \mathrm{U} / \mathrm{L} \text { at day } 11 \text { for } 0.075 \% \mathrm{HA}, 345 \mathrm{U} / \mathrm{L} \text { at day } 11 \text { for } 0.1 \% \mathrm{HA} \\
\text { and } 205 \mathrm{U} / \mathrm{L} \text { at day } 7 \text { for } 0.2 \% \mathrm{HA} \text {. }\end{array}$ \\
\hline $\begin{array}{l}\text { Fakoussa and Frost } \\
\text { (1999) }\end{array}$ & $\begin{array}{l}\text { - HA from lignite } \\
\text { - Trametes versicolor DSM } 3086 \\
\text { - Standing flask cultures with malt extract } \\
\text { medium diluted to } 1 / 5 \text { and } 0.1-4.0 \mathrm{~g} / \mathrm{L} \mathrm{HA} \\
\text { in an incubator at } 30^{\circ} \mathrm{C} \text { and an atmosphere of } \\
40 \text { vol } \% \text { oxygen for } 7 \text { or } 14 \text { days. }\end{array}$ & $\begin{array}{l}\text { - After } 7 \text { days, decolorizations of } 29 \% \text { at } 0.1 \mathrm{~g} / \mathrm{L} \mathrm{HA}, 41 \% \text { at } 0.6 \mathrm{~g} / \mathrm{L} \mathrm{HA}, 33 \% \text { at } \\
1.15 \mathrm{~g} / \mathrm{L}, 24 \% \text { at } 1.55 \mathrm{~g} / \mathrm{L} \text { and } 0.5 \% \text { at } 4 \mathrm{~g} / \mathrm{L} \mathrm{HA} \text { were achieved. } \\
\text { - After } 14 \text { days, decolorizations were } 57.2 \% \text { at } 0.1 \mathrm{~g} / \mathrm{L} \mathrm{HA}, 64.85 \% \text { at } 1.1 \mathrm{~g} / \mathrm{L} \\
\text { HA, } 48 \% \text { at } 2.5 \mathrm{~g} / \mathrm{L} \text { and } 25.1 \% \text { at } 4 \mathrm{~g} / \mathrm{L} \mathrm{HA} \text {. } \\
\text { - These values include adsorption and biodegradation. }\end{array}$ \\
\hline
\end{tabular}




\begin{tabular}{|c|c|c|}
\hline Autor & Fungi, medium and experimental conditions & Comments and results \\
\hline $\begin{array}{l}\text { Kluczek-Turpeinen } \\
\text { et al. (2005) }\end{array}$ & $\begin{array}{l}\text { - } \mathrm{HA} \text { extracted from sieved compost } \\
\text { - Compost-dwelling mold Paecilomycetes } \\
\text { inflatus, strain BKT } 02 \\
\text { - } 250 \text {-mL Erlenmeyer flasks, containing } 50 \mathrm{~mL} \\
\text { culture medium (Czapek-Dox) and } 250 \text { or } \\
500 \mathrm{mg} / \mathrm{L} \mathrm{HA} \text {. The basal medium consisted } \\
\text { of } 2 \mathrm{~g} / \mathrm{L} \mathrm{KH}_{2} \mathrm{PO}_{4}, 0.5 \mathrm{~g} / \mathrm{L} \mathrm{MgSO}_{4} \cdot 7 \mathrm{H}_{2} \mathrm{O}, 0.1 \\
\mathrm{~g} / \mathrm{L} \mathrm{KCl}, 0.5 \mathrm{~g} / \mathrm{L} \text { ammonium tartrate, } 3 \mathrm{~g} / \mathrm{L} \\
\mathrm{NaNO}_{3}, 0.01 \mathrm{~g} / \mathrm{L} \mathrm{FeSO} \mathrm{F}_{4} \text { and } 0.05 \mathrm{~g} / \mathrm{L} \text { yeast } \\
\text { extract }(\mathrm{pH} \text { adjusted to } 7.0 \text { ). Inoculation with } \\
0.5 \mathrm{~mL} \text { of a fungal conidia suspension in } \\
\text { water and incubation at } 28^{\circ} \mathrm{C} \text { for } 31 \text { days }\end{array}$ & $\begin{array}{l}\text { - For } 500 \mathrm{mg} / \mathrm{L} \mathrm{HA} \text {, the biomass increased from } 0 \text { to } 1125 \mathrm{mg} \text { in the first } 4 \text { days, } \\
\text { reached } 1350 \mathrm{mg} \text { at day } 27 \text { and declined to } 850 \mathrm{mg} \text { at } 28 \text { days. For } 250 \mathrm{mg} / \mathrm{L} \\
\mathrm{HA} \text {, the numbers were slightly lower. } \\
\text { - Lac was the only extracellular oxidoreductase detected. In presence of HA, Lac } \\
\text { activity went through a maximum at } 11 \text { days and tended to a constant value } \\
\text { beyond day } 25 \text {. The maximum was of } 60 \mathrm{U} / \mathrm{L} \text { for } 250 \mathrm{mg} / \mathrm{L} \mathrm{HA} \text { and of } 45 \mathrm{U} / \mathrm{L} \\
\text { for } 500 \mathrm{mg} / \mathrm{L} \mathrm{HA} \text {, and the final value of } 30 \mathrm{U} / \mathrm{L} \text { for } 250 \mathrm{mg} / \mathrm{L} \mathrm{HA} \text { and of } 25 \mathrm{U} / \mathrm{L} \\
\text { for } 250 \mathrm{mg} / \mathrm{L} \mathrm{HA} \text {. In absence of HA, activites were always equal or lower than } 5 \\
\text { U/L. } \\
\text { The HA adsorbed on the mycelia was washed by NaOH and added to the } \\
\text { solution. Decolorization of HA (measured by absorbance at } 450 \text { nm) increased } \\
\text { until day } 21 \text { and then remained almost constant. For } 500 \mathrm{mg} / \mathrm{L} \mathrm{HA} \text { they were of } \\
14,22 \text { and } 33 \% \text { at days } 4,11 \text { and } 21 \text {, respectively. For } 250 \mathrm{mg} / \mathrm{L} \text {, they were of } \\
7 \% \text { at day } 4,10 \% \text { at day } 11 \text { and } 30 \% \text { at day } 21 . \text { Size exclusion chromatography } \\
\text { for } 500 \mathrm{mg} / \mathrm{L} \mathrm{HA} \text { showed that the relative concentration of HA (peak area) } \\
\text { decreased by about } 30 \% \text {, being the heavier fractions those preferentially } \\
\text { attacked. } \\
\text { The production of FA was also studied. The rise of absorbance at } 360 \text { nm was of } \\
85 \% \text { for } 500 \mathrm{mg} / \mathrm{L} \mathrm{HA} \text { and of } 70 \% \text { for } 250 \text { mg/L HA. Size exclusion } \\
\text { chromatography for } 500 \text { mg/L HA indicated an increase of only } 25 \% \text { and } \\
\text { modest changes in the molecular-mass distribution. }\end{array}$ \\
\hline
\end{tabular}


Table S4

Comparison of several fungi or of humic compounds under the same experimental conditions for the bleaching.

\begin{tabular}{|c|c|c|}
\hline Autor & Fungi, medium and experimental conditions & Comments and results \\
\hline $\begin{array}{l}\text { Burges and Latter } \\
\text { (1960) }\end{array}$ & $\begin{array}{l}\text { - HA extracted from the B1 horizon of a podzol soil. } \\
\text { - Fungi from the genera Spicaria and Polystictus. } \\
\text { - Penicillin flasks with } 500 \mathrm{~mL} \text { of medium, consisting } \\
\text { of } 0.4 \mathrm{~g} / \mathrm{L} \mathrm{KH}_{2} \mathrm{PO}_{4}, 0.6 \mathrm{~g} / \mathrm{L} \mathrm{K}_{2} \mathrm{HPO}_{4}, 0.5 \mathrm{~g} / \mathrm{L} \\
\mathrm{Mg}_{2} \mathrm{SO}_{4}, 0.5 \mathrm{~g} / \mathrm{L} \mathrm{KCl}, 20 \mathrm{~g} / \mathrm{L} \text { sucrose, trace } \\
\text { elements, Fries' vitamin solution, } 0.2 \mathrm{mg} / \mathrm{L} \text { vitamin } \\
\mathrm{B}_{12}, 0.25 \% \text { agar and } 0.039 \% \mathrm{HA} \text {. Flasks were } \\
\text { inoculated with either a spore suspension of Spicaria } \\
\text { or a mycelial suspension of Polystictus, and } \\
\text { incubated at } 25^{\circ} \mathrm{C} \text { for six weeks. }\end{array}$ & $\begin{array}{l}\text { - The loss of HA (by weight) after incubation was } 16.92 \% \text { for Spicaria and } \\
64.10 \% \text { for Polystictus. Mycelium were treated with warm } 1 \% \text { potassium } \\
\text { phosphate to recover all the adsorbed material. }\end{array}$ \\
\hline
\end{tabular}




\begin{tabular}{|c|c|c|}
\hline Autor & Fungi, medium and experimental conditions & Comments and results \\
\hline $\begin{array}{l}\text { Haider and Martin } \\
\text { (1988) }\end{array}$ & $\begin{array}{l}\text { - HA from a Mollisol (Chernozem near Asel, } \\
\text { Germany) bound to }{ }^{14} \mathrm{C}-\text {-labelled phenols or anilines } \\
\text { (catechol, 4-chlorocatechol, 4,5-dichlorocatechol, } \\
\text { aniline hydrochloride, 4-chloroaniline, } 2 \text { - } \\
\text { chlorophenol, 4-chlorophenol and 2,4- } \\
\text { dichlorophenol) } \\
\text { - Phanerochaete chrysosporium ATCC } 32629 \\
\text { - } 200 \text {-mL Erlenmeyer flasks with } 50 \mathrm{~mL} \text { liquid } \\
\text { medium, containing the mineral salts and vitamins of } \\
\text { Kirk et al. (1978), } 0.56 \mathrm{mmol} / \mathrm{L} \mathrm{D}-\mathrm{glucose} \text { as carbon } \\
\text { source, } 0.6 \mathrm{mmol} / \mathrm{L} \mathrm{NH}_{4} \mathrm{NO}_{3} \text { and } 0.6 \mathrm{mmol} / \mathrm{L} \mathrm{L-} \\
\text { asparagine as nitrogen sources and } 400 \mathrm{mg} / \mathrm{L} \mathrm{HA} \text {, } \\
\text { inoculated with spores and held at } 35^{\circ} \mathrm{C} \text { for } 18 \text { days. }\end{array}$ & $\begin{array}{l}\text { - The chlorinated aromatic moieties were biodegradation intermediates of } \\
\text { herbicides and insecticides, which were known to be immobilized in soil by } \\
\text { binding to the humus matrix. The main objective of the experiment was to } \\
\text { determine if the fungus was able of mineralizing them as well as the non- } \\
\text { chlorinated ones, which were known to be units of the HA. } \\
\text { The percentage of HA converted into }{ }^{14} \mathrm{CO}_{2} \text { increased with the incubation } \\
\text { time. After } 18 \text { days it was of } 32.5 \% \text { for catechol, } 35.5 \% \text { for } 4- \\
\text { chlorocatechol, } 37.8 \% \text { for } 4,5 \text {-dichlorocatechol, } 20.1 \% \text { for aniline } \\
\text { hydrochloride, } 13.4 \% \text { for } 4 \text {-chloroaniline, } 30.8 \% \text { for } 2 \text {-chlorophenol, } 17.4 \% \\
\text { for } 4 \text {-chlorophenol and } 17.1 \% \text { for } 2,4 \text {-dichlorophenol. } \\
\text { For the sake of comparison, } 0.2 \text { mg of each }{ }^{14} \mathrm{C}-1 \text { labelled chlorinated } \\
\text { compound were added to the } 50 \text { mL medium without HA. After } 18 \text { days, } \\
\text { the free } 4 \text {-chlorocatechol and the two anilines were more slowly degraded } \\
\text { than when linked into the humic matrix, whereas catechol, } 2 \text {-chlorophenol } \\
\text { and 4-chlorophenol were degraded faster. } 4,5 \text {-dichlorocatechol and } 2.4- \\
\text { dichlorophenol displayed almost the same mineralization }\end{array}$ \\
\hline
\end{tabular}

Dehorter et al. (1992)
- HA from the upper horizon of a forest soil, with two modal masses: $6.8 \mathrm{kDa}$ and $160 \mathrm{kDa}$. Elementary analysis gave $49.8 \% \mathrm{C}, 5.1 \% \mathrm{H}$ and $3.2 \% \mathrm{~N}$ (ash free). $26.7 \%$ of the $\mathrm{C}$ was aliphatic, $26.0 \%$ of the $\mathrm{C}$ was alkyl $\mathrm{C}$ united to -O- (ether or alcohol), $37.5 \%$ of the $\mathrm{C}$ was aromatic and the remaining was $\mathrm{C}$ of carboxylic groups.

- P. chrysosporium and T. versicolor in the same conditions than Dehorter and Blondeau (1992), but with $100 \mathrm{~mL}$ medium, without veratryl alcohol and incubated at $35^{\circ} \mathrm{C}$
- Reaction was stopped after $30 \%$ loss of absorbance at $350 \mathrm{~nm}$ ( $5-8$ days), but one culture of $P$. chrysososporium was carried out up to $60 \%$. None is said about the HA adsorbed on the mycelium.

- Gel filtration chromatography for HA after $30 \%$ bleaching revealed that fractions around $160 \mathrm{kDa}$ were more attacked than those around $6.8 \mathrm{kDa}$.

- ${ }^{13} \mathrm{C}$ NMR spectroscopy of the degradated HA indicated that the relative abundance of aromatic $\mathrm{C}$ did not vary considerably when compared with that of the original HA, that the results for $60 \%$ bleaching with $P$. chrysosporium were close to those for $30 \%$ bleaching, that only $P$. chrysosporium modified the proportion of carboxylic C (to $8.4-8.9 \%$ ), that fungal attack increased the abundance of aliphatic $\mathrm{C}$ to $27.1-27.6 \%$ and that the proportions of alkyl $\mathrm{C}$ united to $-\mathrm{O}$ - (ether or alcohol) were 26.2 $26.66 \%$ for $P$. chrysosporium and $24.9 \%$ for T.versicolor. 
Ralph et al. (1996) - The same HA and experimental conditions than Ralph et al. (1996) in Table S2, but only $15 \mathrm{~mL}$ of low nitrogen medium.

- The same three fungi plus other four white-rot fungi (Ganoderma applanatum DFP 12073, Pycnoporus cinnabarinus FPRL 176, Rigidoporus ulmarius FPRL 241D and Trametes versicolor ATCC 12679) and two brown-rot fungi (Gloeophyllum trabeum DFP 7520 and Lentinus lepideus DFP 2385)
- G. trabeum gave $18 \mathrm{mg}$ biomass, $3.1 \%$ bleaching and 5.5\% decrease in modal mass; L. lepideus gave $47.2 \mathrm{mg}$ biomass, $5.7 \%$ bleaching and $2.8 \%$ decrease in modal mass; G. applanatum gave $37.7 \mathrm{mg}$ cells, $-15.5 \%$ decolorization and a $33.7 \%$ increase in modal mass; M. tremellosus gave $39.1 \mathrm{mg}$ cells, $25.1 \%$ decolorization and $95.7 \%$ increase in modal mass; $P$. tephropora produced $55.7 \mathrm{mg}$ biomass, $0.0 \%$ bleaching and $32.6 \%$ increase in modal mass; $P$. chrysosporium gave $36 \mathrm{mg}$ biomass, $10.2 \%$ bleaching and $46.7 \%$ increase in modal mass; $P$. cinnabarinus generated $13 \mathrm{mg}$ biomass, $-19.6 \%$ decolorization and $6.2 \%$ increase in modal mass; $R$. ulmarius generated $38.4 \mathrm{mg}$ cells, $16.4 \%$ decolorization and $27.1 \%$ increase in modal mass; and T. versicolor generated $42.9 \mathrm{mg}$ cells, $-7.4 \%$ decolorization and $4.6 \%$ increase in modal mass.

- Enzymatic activities (measured in media without HA) went through maxima with incubation times. LiP was detected only for P. chrysosporium, $\mathrm{MnP}$ for M. tremellosus, $P$. tephropora and $P$. chrysosporium, and Lac for $M$. tremellosus, P. tephropora, R. ulmarius and T. versicolor. However, the authors suspected of the presence of enzymes bounded to the cells of $G$. applatanatum and P. cinnabarinus (instead of extracellular ones).

\section{Ralph and}

Catcheside (1998b)
- HA from Morwell brown coal, soluble in water below pH 6

- The white-rot fungus Phanerochaete chrysosporium strains ME446 (which produces both MnP and LiP) and ME446-B17-1 (which produces only MnP)

- The low-nitrogen medium and the same conditions than Ralph and Catcheside (1994) in Table S1, with $200 \mu \mathrm{mol} / \mathrm{L} \mathrm{Mn}$ (II) and incubation for 16 days under hyperbaric oxygen.
- The strains were selected to known if, under hyperbaric oxygen, MnP was responsible of polymerization, and if the combination of both $\mathrm{MnP}$ and $\mathrm{LiP}$ caused depolymerization.

- For the ME446, MnP activity was zero at day 3, reached a maximum of 160 $\mathrm{U} / \mathrm{L}$ at day 6 and decreased to zero at day 14, whereas LiP activity was zero before day 6 and after day 14, peaking at day 8 (86 U/L). For the ME446B17-1, MnP was zero before day 8 , went through a maximum of $90 \mathrm{U} / \mathrm{L}$ at day 11 and decreased to $10 \mathrm{U} / \mathrm{L}$ at day 16 .

- The modal mass of the residual HA (gel permeation chromatography) and the absorbance at $400 \mathrm{~nm}$ fell by $39 \%$ and $50 \%$ respectively after 16 days 


\begin{tabular}{ll}
\hline Autor & Fungi, medium and experimental conditions \\
\hline
\end{tabular}

Fakoussa and Frost (1999)

- HA from lignite
- The tested fungi were Trametes versicolor, Phanerochaete chrysosporium,

- Pycnoporus cinnabarinus, Pleurotus ostreatus, Heterobasidion annosum, Fusarium oxysporum, Paecilomyces farinosus, Lentinula edodes and two unknown strains called RB 18 and RBS $1 \mathrm{~K}$.

- Cultures were incubated in 100- to 200-mL flasks and shaken with a $20 \%$ filling of liquid (malt extract medium diluted to $1 / 5$ and $0.05 \% \mathrm{HA}$ ) at temperatures between 27 and $35^{\circ} \mathrm{C}$ depending on the strain. Flasks were sealed by silicone sponge stoppers.
Comments and results

for ME446, whereas for the peroxidase-deficient strain, the mass increased by $48 \%$ and the absorbance fell by less than $20 \%$. In the two cases, the HA adsorbed by the mycelia were recovered by alkali washing and added to the solution.

- Decolorizations (estimated by the decrease of absorbance at $450 \mathrm{~nm}$ ) were $80 \%$ for $T$. versicolor, $5 \%$ for $F$. oxysporum, $4 \%$ for $H$. annosum, $45 \%$ for P. farinosus, $4 \%$ for RB $18,70 \%$ for RBS $1 \mathrm{~K}, 2.5 \%$ for $L$. edodes, $48 \%$ for $P$. cinnabarinus, $78 \%$ for $P$. chrysosporium and $52 \%$ for $P$. ostreatus.

These values include the effects of both biodegradation and biosorption.

- Lac was the dominating enzyme for T. versicolor, H. annosum, $P$. farinosus, $P$. cinnabarinus and $P$. ostreatus, whereas peroxidase was it for F. oxysporum, RB 18, RBS 1K, L. edodes and P. chrysosporium.
Gramss et al. (1999)
- HS from a black calcareous forest mull, with a modal mass around $1.3 \mathrm{kDa}$.

- Eight wood-degrading basidiomycetes, white-rot type (Bjerkandera adusta, Clitocybula dusenii, Gymnopilus sapineus, Hypholoma fasciculare, $H$. frowardii, Kuehneromyces mutabilis, Pleurotus

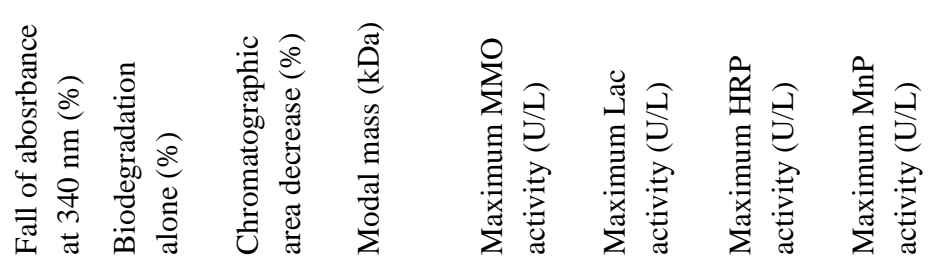




\begin{tabular}{|c|c|c|c|c|c|c|c|c|c|c|}
\hline Autor & Fungi, medium and experimental conditions & Comments and $\mathrm{r}$ & ults & & & & & & & \\
\hline & 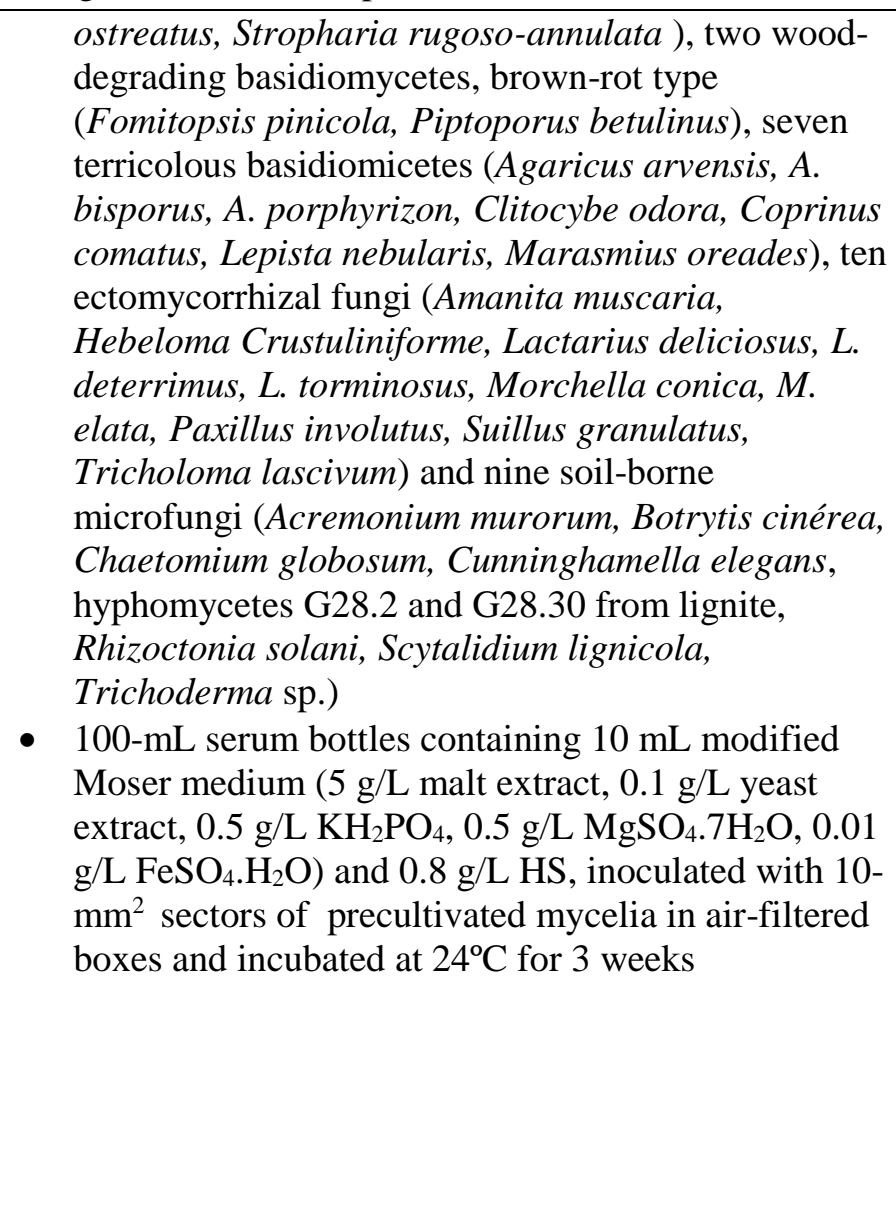 & $\begin{array}{l}\text { B. adusta } \\
\text { C. dusenii } \\
\text { G. sapienus } \\
\text { H. fasciculare } \\
\text { H. frowardii } \\
\text { K. mutabilis } \\
\text { P. ostreatus } \\
\text { S. rugoso-annulata } \\
\text { F. pinicola } \\
\text { P. betulinus } \\
\text { A. arvensis } \\
\text { A. bisporus } \\
\text { A. porphyrizon } \\
\text { C. odora } \\
\text { C. comatus } \\
\text { L. nebularis } \\
\text { M. oreades } \\
\text { A. muscaria } \\
\text { H. crustuliniforme } \\
\text { L. deliciosus } \\
\text { L. deterrinus } \\
\text { L. torminosus } \\
\text { M. conica } \\
\text { M. elata } \\
\text { P. involutus } \\
\text { S. granulatus } \\
\text { T. lascivum } \\
\text { A. murorum } \\
\text { B. cinerea } \\
\text { C. globosum } \\
\text { C. elegans } \\
\text { G } 28.2 \\
\text { G. } 28.30 \\
\text { R. solani } \\
\text { S. lignicola } \\
\text { Trichoderma sp. }\end{array}$ & $\begin{array}{l}55.5 \\
56.2 \\
45.9 \\
53.8 \\
73.1 \\
41.9 \\
41.3 \\
56.7 \\
72.3 \\
71.5 \\
25.1 \\
26.3 \\
32.9 \\
28.7 \\
32.3 \\
31.6 \\
15.7 \\
12.7 \\
18.7 \\
17.5 \\
13.9 \\
8.1 \\
31.8 \\
34.4 \\
11.7 \\
2.9 \\
18.3 \\
25.6 \\
36.7 \\
2.5 \\
16.5 \\
1.8 \\
25.9 \\
21.1 \\
77 \\
25.4\end{array}$ & $\begin{array}{l}50.1 \\
40.6 \\
51.7 \\
68.4 \\
40.6 \\
\\
44.8 \\
47.1 \\
49.5 \\
\\
24.4\end{array}$ & $\begin{array}{l}27.5 \\
38.6 \\
0 \\
\\
30.8 \\
27.9\end{array}$ & $\begin{array}{l}0.83 \\
0.89 \\
0.85 \\
\\
0.87 \\
1.02 \\
1.05 \\
\\
1.3 \\
\\
1.3 \\
\\
1.3 \\
1.3\end{array}$ & $\begin{array}{l}0.06 \\
3.7 \\
0 \\
0.04 \\
3.0 \\
1.3 \\
8.0 \\
1.08 \\
0 \\
0 \\
4.9 \\
19.0 \\
7.6 \\
2.0 \\
5.4 \\
1.3 \\
0.46 \\
0.1 \\
0 \\
0.47 \\
1.5 \\
20.0 \\
2.7 \\
0.31 \\
0 \\
0 \\
0.08 \\
0 \\
0.18 \\
0 \\
0 \\
0 \\
0 \\
0.2 \\
0.58 \\
0\end{array}$ & $\begin{array}{l}0.005 \\
31.4 \\
4.2 \\
8.9 \\
6.4 \\
15.3 \\
6.3 \\
7.2 \\
0 \\
0 \\
1.5 \\
16.2 \\
11.9 \\
7.5 \\
3.9 \\
4.4 \\
0.12 \\
0.06 \\
0 \\
0.58 \\
30.3 \\
22.2 \\
2.0 \\
0.57 \\
0.5 \\
0.023 \\
0.35 \\
0 \\
0.015 \\
0 \\
0 \\
0.004 \\
0 \\
0 \\
0.12 \\
0\end{array}$ & $\begin{array}{l}0 \\
0 \\
0 \\
0.26 \\
1.9 \\
0.43 \\
1.7 \\
1.2 \\
0 \\
0 \\
0 \\
0 \\
2.0 \\
0.36 \\
0.53 \\
0.49 \\
0 \\
0 \\
0 \\
0.56 \\
2.6 \\
2.06 \\
0.39 \\
0.09 \\
0.83 \\
0 \\
0.34 \\
0 \\
0.03 \\
0 \\
0 \\
0.47 \\
0 \\
0 \\
0.13 \\
0\end{array}$ & $\begin{array}{l}9.0 \\
16.2 \\
0 \\
49.5 \\
19.0 \\
7.3 \\
8.4 \\
34.2 \\
0 \\
0 \\
0 \\
0.58 \\
0.07 \\
0 \\
0.05 \\
0 \\
0 \\
0 \\
0.15 \\
0 \\
0 \\
0 \\
0.48 \\
0.05 \\
0 \\
0 \\
0 \\
0 \\
0 \\
0 \\
0 \\
0 \\
0 \\
0 \\
0 \\
0\end{array}$ \\
\hline
\end{tabular}

Temp et al. (1999)
- HS from german lignite. The humic fraction had a modal mass of $2.76 \mathrm{kDa}$, and the fulvic fraction a modal mass around $1-2 \mathrm{kDa}$.
- Decolorizations (as reductions of the absorbance at $465 \mathrm{~nm}$ ) were of $25 \%$ at 8 days, $75 \%$ at 18 days and of $94 \%$ beyond 18 days for JF 596, of $26 \%$ at 8 days, $49 \%$ at 10 days and $71 \%$ at 20 days for $P$. cinnabarinus and of $7 \%$ at 


\begin{tabular}{|c|c|c|}
\hline Autor & Fungi, medium and experimental conditions & Comments and results \\
\hline & $\begin{array}{l}\text { - The white-rot fungi Pycnoporus cinnabarinus } \\
\text { (ATCC 200478), Polyporus ciliatus and an } \\
\text { unidentified white-rot basidiomycete JF 596, isolated } \\
\text { from decaying soft wood in Thuringa } \\
\text { - Mycelia from } 10 \text { agar blocks }(0.5 \mathrm{~cm} \text { x } 0.5 \mathrm{~cm}) \text { taken } \\
\text { from the edge of actively growing colonies cultured } \\
\text { on malt extract agar plates were used as inoculum for } \\
250 \mathrm{~mL} \text { Erlenmeyer flasks containing } 75 \mathrm{~mL} \text { of } \\
\text { liquid modified Dodson medium and } 1.7 \mathrm{~g} / \mathrm{L} \mathrm{HS} \text {. } \\
\text { The pH of the medium was adjusted to } 4.6 \text { with } 1 \mathrm{M} \\
\text { NaOH. The strains were grown in shaken cultures } \\
\text { (140 rpm) for } \\
20 \text { days at } 24^{\circ} \mathrm{C} \text {. }\end{array}$ & $\begin{array}{l}5 \text { days and of } 41 \% \text { beyond } 18 \text { days for } P \text {. ciliatus. Adsorption to mycelial } \\
\text { pellets was analyzed, but it resulted to be negligible. } \\
\text { - JF } 596 \text { produces Lac, MnP and LiP. P. Cinnabarimus only generates Lac. } \\
P \text {. ciliatus produces both Lac and MnP. See Figure } 2 \text {. } \\
\text { - Gel permeation chromatography of HA after } 20 \text { days revealed a decrease of } \\
\text { the chromatographic area of } 72 \% \text { for JF } 596 \text {, of } 58 \% \text { for } P \text {. cinnabarinus } \\
\text { and of } 34 \% \text { for } P \text {. ciliatus. The modal mass in the HA slightly decreased for } \\
\text { JF } 596 \text { but increased a little for } P \text {. cinnabarinus and } P \text {. ciliatus. } \\
\text { - The production of FA was also investigated. The increase in the } \\
\text { chromatographic area of FA was of } 161 \% \text { for JF } 596,101 \% \text { for } P \text {. } \\
\text { cinnabarinus and of } 14 \% \text { for } P \text {. ciliatus. The modal mass of the FA } \\
\text { remained unchanged for the three fungi. }\end{array}$ \\
\hline $\begin{array}{l}\text { Yanagi et al. } \\
(2002)\end{array}$ & $\begin{array}{l}\text { - HA from five Japanese soils (Umbri Andosol } 1 \text { and } \\
\text { 2, Dystric Cambisol } 1 \text { and } 2 \text { and Fibric Histosol) } \\
\text { - Three fungi (Corioulus consors IFO 9078, Coriolus } \\
\text { hirsutus IFO } 4917 \text { and Lenzites betulina IFO 6266) } \\
\text { isolated from the soil belonging to Umbric Andosol.) } \\
\text { - Test tubes containing } 10 \mathrm{~mL} \text { of Czapek-Dox medium } \\
\text { with } 0.05 \% \mathrm{w} / \mathrm{v} \mathrm{HA}, \mathrm{pH} \text { adjusted to 6.8, inoculated } \\
\text { and kept at } 25^{\circ} \mathrm{C} \text { for } 21 \text { days in stationary incubators. }\end{array}$ & $\begin{array}{l}\text { - Cambisol HA were characterized as having higher content of carbohydrate } \\
\text { C, lower contents of aromatic C and lower degree of aromaticity than } \\
\text { Andosol HA and Histosol HA. } \\
\text { - Decolorizations were evaluated by absorbance at } 600 \mathrm{~nm} \text {. None is said } \\
\text { about the HA adsorbed to the cells. C. consors gave } 25.9 \% \text { for Andisol } 1 \text {, } \\
27.7 \% \text { for Andisol } 2,29.3 \% \text { for Histosol, } 41.6 \% \text { for Cambisol } 1 \text { and } 51.1 \% \\
\text { for Cambisol } 2 . \text { C. hirsutus gave } 2.6 \% \text { for Andisol } 1,31.1 \% \text { for Andisol } 2 \text {, } \\
9.9 \% \text { for Histosol, } 37.3 \% \text { for Cambisol } 1 \text { and } 45.5 \% \text { for Cambisol } 2 . L \text {. } \\
\text { betulina gave }-0.9 \% \text { for Andisol } 1,17.5 \% \text { for Andisol } 2,2.6 \% \text { for Histosol, } \\
11.8 \% \text { for Cambisol } 1 \text { and } 50.6 \% \text { for Cambisol } 2 \text {. }\end{array}$ \\
\hline
\end{tabular}

Yanagi et al.

- Soil HA from 15 Japanese sites (7 Andisols, 4 Inceptisols, 2 Ultisols, 1 Mollisol and 1 Histosol)
- The HA adsorbed by the cells was recovered by $\mathrm{NaOH}$ washing, and added to the solutions. Decolorizations (evaluated by absorbance reduction at 600 


\begin{tabular}{ll}
\hline Autor & Fungi, medium and experimental conditions \\
\hline (2003) & White-rot fungus Coriolus consors IFO 9078 \\
& - Test tubes containing $5 \mathrm{~mL}$ Czapek-Dox liquid \\
& medium at pH 6.8 and $0.25 \mathrm{~g} / \mathrm{L} \mathrm{HA}$, inoculated with \\
& a loopful of fungal hyphae from a slant culture on \\
& popato sucrose agar and kept at $25^{\circ} \mathrm{C}$ for 14 days in \\
& stationary incubators
\end{tabular}
stationary incubators

Kabe et al. (2005)

- HA from german lignite

- Three white-rot fungal strains (FTN, WO-4, and WT-5) isolated from decaying woods of Japan, but not identified taxonomically.

- 100-mL Erlenmeyer flasks containing $10 \mathrm{~mL}$ of the basal medium of Willmann and Fakoussa (1997) at pH 5.6, supplemented with 50 ppm veratryl alcohol and 1000 ppm HA, inoculated with $0.5 \mathrm{~mL}$ of cell suspensions and incubated statically at $28^{\circ} \mathrm{C}$ for 20 or 63 days.
Comments and results

$\mathrm{nm}$ ) were $18.8 \%$ for the Andisol HA from Gyoseizan, $22.2 \%$ for the

Andisol HA from Hachibuse, $19.3 \%$ for the Andisol HA from Inogashira, $19.9 \%$ for the Andisol HA from Makino, $8.8 \%$ for the Andisol HA from

Oginosen, $18.1 \%$ for one Andisol HA from Sugadaira (grassland), 31.8\% for other Andisol HA from Sugadaira (forest), 39.5\% for the Inceptisol HA from Dando, 36.2\% for the Inceptisol HA from Hanaore, $38.2 \%$ for the Inceptisol HA from Keirozan, 29.5\% for the Inceptisol HA from Nagamine, $23.9 \%$ for the Ultisol HA from Andover, 23.2\% for the Ultisol HA from Miyagi, $18.0 \%$ for the Mollisol HA from Wakau and $18.4 \%$ for the Histosol HA from Ichijima.

- Absorbances, aromaticities (determined by ${ }^{13} \mathrm{C}$-nuclear magnetic resonance), total acidities, elemental compositions $(\mathrm{C}, \mathrm{H}, \mathrm{N}, \mathrm{O})$ and atomic ratios $(\mathrm{H} / \mathrm{C}, \mathrm{O} / \mathrm{C}, \mathrm{N} / \mathrm{C}, \mathrm{O} / \mathrm{H}$ from the elemental compositions) for the HAs before the reaction were measured, in order to correlate the decolorization with some of these properties.

- Adsorbed HA was recovered by $\mathrm{NaOH}$ washing and added to the solutions. Absorbances at 480 and $275 \mathrm{~nm}$ served to calculate decolorizations and depolymerizations, respectively.

- For FTN, decolorizations were of $50 \%$ at 7 days and of $73 \%$ at 20 days, whereas depolymerizations were $22 \%$ at day $7,32 \%$ at day 15 and $26 \%$ at day 20.

- For WO-4, decolorizations were of $56 \%$ at 7 days, $67 \%$ at 27 days, $71 \%$ at 56 days and $84 \%$ at 63 days, whereas depolymerizations were $29 \%$ at day $14,38 \%$ at day $27,39 \%$ at day 56 and $55 \%$ at 63 days.

- For WT-5, decolorizations were of $47 \%$ at 7 days and of $70 \%$ at 56 days, whereas depolymerizations were $24 \%$ at day $7,32 \%$ at day 15 and $38 \%$ at day 56 . From day 56 to day 63, both parameters slightly decreased.

- Activities of Lac, LiP, MnP and AAO were determined in a HA-free medium. For FTN, MnP alone correlated well with the adsorbance reductions. For the other two fungi, the combination of both MnP and Lac 


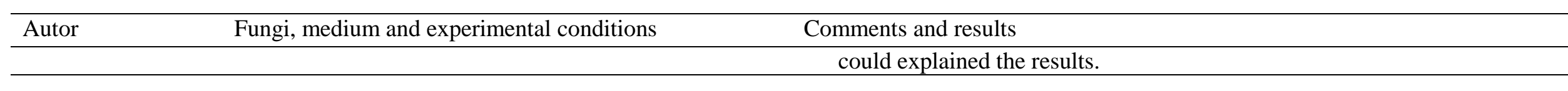

Belcarz et al.

(2005)

(2006)
- HA from chernozem $(51.4 \% \mathrm{C}, 3.96 \% \mathrm{H}, 3.58 \% \mathrm{~N}$, $2.87 \%$ ash, $3.296 \%$ phenolics) and lessive soil (51.54\% C, $4.41 \% \mathrm{H}, 2,9 \% \mathrm{~N}, 4.14 \%$ ash, $3.132 \%$ phenolics)

- Bjerkandera adusta R59, a white-rot fungus isolated from black earth soil.

- Erlenmeyer flasks (300 mL) containing $100 \mathrm{~mL}$ of Fahreus medium with $0.07 \%$ glucose and $0.03 \%$ HA. Sterile conditions. $2 \mathrm{~mL}$ of inoculum. Reaction for 21 days at $26^{\circ} \mathrm{C}$

- FA from an arable soil (clay-loam orthic luvisol) in Prague.

- Eight soil microfungi (Alternaria alternata, Clonostachys rosea, Paecilomyces lilacinus, Phoma sp, Penicillium canescens, Exophiala cf. salmonis, Fusarium caeruleum and Fusarium redolens) and two white-rot fungi( Phanerochaete chrysosporium and Trametes versicolor)

- 100-mL Erlenmeyer flasks with 10 mL FA solution and $0.5 \mathrm{~mL}$ mineral solution, inoculated with $0.5 \mathrm{~mL}$ of a homogenized mycelial suspension of each microfungal species and incubated for 1 month. Mineral stock solution contained $2920 \mathrm{mg} / \mathrm{L}$ $\mathrm{Ca}\left(\mathrm{NO}_{3}\right)_{2} \cdot 4 \mathrm{H}_{2} \mathrm{O}, 1957 \mathrm{mg} / \mathrm{L} \mathrm{MgSO}_{4} \cdot 7 \mathrm{H}_{2} \mathrm{O}, 972$ $\mathrm{mg} / \mathrm{L} \mathrm{CaCl}_{2} .2 \mathrm{H}_{2} \mathrm{O}, 704 \mathrm{mg} / \mathrm{L} \mathrm{Na}_{2} \mathrm{SO}_{4}, 193 \mathrm{mg} / \mathrm{L}$ $\mathrm{KNO}_{3}, 45 \mathrm{mg} / \mathrm{L} \mathrm{K}_{2} \mathrm{HPO}_{4}, 25 \mathrm{mg} / \mathrm{L} \mathrm{NH}_{4} \mathrm{NO}_{3}$ and 6 $\mathrm{mg} / \mathrm{L} \mathrm{KH}_{2} \mathrm{PO}_{4}$
- Decolorization (measured by changes in absorbance at $450 \mathrm{~nm}$ ) was moderate in HA from lessive soil $(0 \%$ at 1 day, $42 \%$ at 7 days and $58 \%$ at 21 days) and low in HA from chernozem (0\% at 1 day, $22 \%$ at 7 days and $37 \%$ at 21 days). None is said about the HA adsorbed to the mycelium.

- Extracellular peroxidase activities were slightly higher for HA from lessive soil than for HA from chernozen, and went through a maximum around 10 $\mathrm{mU} / \mathrm{L}$ at 14 days. Lac activities were negligible in both cases.

- Concentrations of phenolic compounds (as vanillic acid, measured at 500 $\mathrm{nm}$ ) were $8.24 \mathrm{mg} / \mathrm{L}$ for media with HA from chernozem and $7.83 \mathrm{mg} / \mathrm{L}$ for HA from lessive soil. They quickly decreased in the first day of reaction, being below $2 \mathrm{mg} / \mathrm{L}$ between days 1 and 21 .

- Decolorization (as reduction of absorbance at $665 \mathrm{~nm}$ ) or change of the molecular mass of the FA (evaluated by the ratio of the absorbances at 465 $\mathrm{nm}$ and $665 \mathrm{~nm}$ ) were not significant for any fungus. Reduction of the amount of phenolics (as decrease of absorbance at $280 \mathrm{~nm}$ ) was only important for P. lilacinus $(-10.4 \%)$ and T. versicolor $(-11.8 \%)$. None is said about the influence of FA adsorption by the cells in the absorbance reduction. The amount of biomass produced was of around $75.3 \mathrm{mg}$ for $F$. coeruleum, $55.5 \mathrm{mg}$ for Phoma sp. and E. cf. salmonis, $45 \mathrm{mg}$ for $P$. canescens and F. redolens, 34- $37 \mathrm{mg}$ for A. alternate, $C$. rosea and $P$. lilacinus, $8.8 \mathrm{mg}$ for $P$. chrysosporium and $2.4 \mathrm{mg}$ for $T$. versicolor,

- Average values of $\mathrm{MnP}$ activities from the third to the $28^{\text {th }}$ days of incubation were $0.66 \mathrm{U} / \mathrm{L}$ for $A$. alternata, $0.45 \mathrm{U} / \mathrm{L}$ for $C$. rosea, $0.43 \mathrm{U} / \mathrm{L}$ for $P$. lilacinus and $0.91 \mathrm{U} / \mathrm{L}$ for Phoma sp. Average values for Lac and other peroxidases were of $0.02-0.04 \mathrm{U} / \mathrm{L}$, except for $C$. rosea $(0.11 \mathrm{U} / \mathrm{L}$ Lac), P. lilacinus (0.07 U/L Lac) and Phoma sp. (0.15 U/L other peroxidases). The TOC of the remaining solutions with these four soil fungi did not considerably differ from that of the initial FA solutions. 


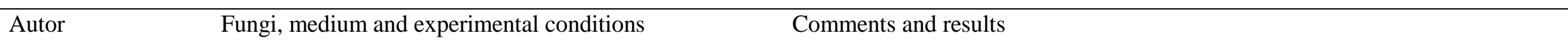

Kornillowicz-

Kowalska et al.

(2008)

Grinhut et al.

(2011a)
- HA from brown coal, chernozem and lessive soil

- Anamorphic basidiomycete Bjerkandera adusta R 59 strain, isolated from a black earth soil.

- 100-mL Erlenmeyer flasks were filled with $50 \mathrm{~mL}$ Park and Robinson medium containing $0.01 \%$ HA and $0.25 \%$ glucose, inoculated with $1 \mathrm{~mL}$ of homogenized mycelium $\left(10^{5} \mathrm{CFU} / \mathrm{mL}\right)$ and stationarilly incubated at $26^{\circ} \mathrm{C}$ up to 60 days

- HA from composted biosolids, with $48.8 \%$ C, $5.6 \%$ $\mathrm{H}, 7.5 \% \mathrm{~N}, 36 \% \mathrm{O}$ and $2.1 \% \mathrm{~S}$ (ash-free) and a modal mass around $10.7 \mathrm{kDa}$.

- White-rot fungi Trametes sp. M23 and Phanerochaete sp. Y6 isolated from composted biosolids and grown on potato-dextrose agar.

- The same low nitrogen medium and experimental conditions than Grinhut et al. (2011b), incubated for 8 days.
- The decolorization of HA from chernozem, brown coal and lessive soil on day 7 corresponded to 60,38 and $17 \%$ loss of their initial absorbance at 400 $\mathrm{nm}$, respectively. Thereafter, bleaching augmented steadily and after 60 days it finally reached $90.5,83$ and $74 \%$ for HA from chernozem, brown coal and lessive soil, respectively. The initial strong decrease in the HA from chernozem was not due to adsorption, which did not exceed $6 \%$ of total HA removal.

- Growth of B. adusta was assessed qualitatively by observing the formation of aerial mycelium.

- Peroxidase activities went through maxima with time. These maxima were of 13.27 U/L at 21 day for brown coal, 11.95 U/L at day 35 for lessive soil and $7.7 \mathrm{U} / \mathrm{L}$ at day 28 for chernozem. At the end of the experiment, the enzyme activities dropped to values less than $10 \%$ of its maximum value

- Methoxyphenolic or vanillic acid levels (as absorbance at $500 \mathrm{~nm}$ ) for HA from lessive soil were of 100, 76 and $70 \%$ at days 10, 24 and 60, respectively; for HA from chernozen were of $90,89,69$ and $63 \%$ at days 3 , 14, 24 and 60, respectively; for HA from brown coal were of 85, 84, 76 and $70 \%$ after $3,24,28$ and 60 days.

- Decolorizations (estimated by absorbance at $465 \mathrm{~nm}$ ) of $52 \%$ at day 5 and $63 \%$ at day 8 for Trametes sp. M23 and of $41 \%$ at day 3 and $78 \%$ at day 8 for Phanerochaete sp. Y6 were achieved. None is said about adsorption.

- Size exclusion chromatography after 8 days revealed a preferential attack to the high-size fraction. The modal mass for the Trametes sp. M23 was around $4.5 \mathrm{kDa}$. The distribution achieved by Phanerochaete sp. Y6 was roughly bimodal (peaks at 3 and $0.4 \mathrm{kDa}$ ).

- Elemental analysis after 8 days indicated an increase in the $\% \mathrm{O}$ and a decrease of $\% \mathrm{C}$ and $\% \mathrm{~N}$. The $\mathrm{O}$ increase was higher for Trametes sp. M23 than for Phanerochaete sp. Y6.

- Proton nuclear magnetic resonance displayed a decrease in aromaticity and 


\begin{tabular}{|c|c|c|}
\hline Autor & Fungi, medium and experimental conditions & Comments and results \\
\hline & & $\begin{array}{l}\text { an increase of oxygen-containing groups (specially, for Trametes sp. M23) } \\
\text { - Fourier transform cyclotron resonance mass spectrometry showed } \\
\text { consecutive series of masses linked to biochemical pathways such as } \\
\text { demethylation, side chain oxidation, hydrolysis and aromatic ring cleavage. }\end{array}$ \\
\hline
\end{tabular}

\section{Table S5.}

Operational features of some fungal decolorizations, not previously cited.

Autor
Mathur and Paul (1966, 1967),

Paul and Mathur (1967)
Fungi, medium and experimental conditions

- HA from the Ap horizon of Melfort Orthic Black soil, with $54 \% \mathrm{C}, 4.76 \% \mathrm{H}, 3.89 \% \mathrm{~N}$ and $37.4 \% \mathrm{O}$ (ash-free)

- Penicillium frequentans from the same soil

- $0.02 \%$ HA in a Czapek Dox broth without sucrose. Inoculation with mycelium and incubation for 7 weeks at room temperature with shaking.
Comments and results

- In the shaken culture inoculated with mycelium, the absorbance at 465 nm decreased a $31.6 \%$ when HA was the source of $\mathrm{C}$. This bleaching was only caused by biodegradation.

- The partially degraded HA contained $54.2 \% \mathrm{C}, 4.90 \% \mathrm{H}, 4.74 \% \mathrm{~N}$ and $36.2 \% \mathrm{O}$ (ash-free). Infrared spectra showed a considerable increase in the hydroxyl content and a moderate increase in the phenolic hydroxyl and the carboxyl groups.

- The ratio between the absorbances at 465 and $665 \mathrm{~nm}$, increased a $11.6 \%$, which indicated a decrease of the aromaticity (and therefore, a preferential attack to the aromatic portion of the HA)

- Gel chromatography indicated that molecular weights of HA varied from less than 5000 to more than 50000 and that the fungus preferred to degrade moieties larger than 50000. However, further experiments separated the HA in four fractions $(>35000,8000$ - 35000, $6000-$ 8000 and $6000<$ ), and found that the lighter fraction was the most susceptible of attack (followed by the heaviest fraction). This suggested that, in the mixture, the larger molecules were not fully decomposed, but converted to intermediate and small-sized molecules. 


\begin{tabular}{|c|c|c|}
\hline Autor & Fungi, medium and experimental conditions & Comments and results \\
\hline Willmann and Fakoussa (1997) & $\begin{array}{l}\text { - The same HA, fungal strain and malt extract } \\
\text { medium described in Table S3, but with } \\
0.05 \% \text { HA }\end{array}$ & $\begin{array}{l}\text { - Decolorization of } 82 \% \text { was reached after } 13 \text { days, but most of it } \\
\text { happened between days } 6 \text { and } 7 \text { (increase from } 20 \% \text { to } 65 \% \text { ). These } \\
\text { values includes both adsorption and biodegradation. } \\
\text { - MnP activities were of } 20,35,82,116 \text { and } 39 \mathrm{U} / \mathrm{L} \text { at days } 5,6,10,11 \\
\text { and 13, respectively. } \\
\text { - Gel permeation chromatography indicated a decrease of the modal } \\
\text { mass. } \\
\text { - }{ }^{13} \mathrm{C} \text {-nuclear magnetic resonance revealed an increase of carboxylic } \\
\text { groups, hydroxylated and methoxylated aliphatic groups and a } \\
\text { decrease in aromatics. Elemental analysis showed a high increase of } \mathrm{N} \\
\text { and } \mathrm{O} \text {, a moderate rise of } \mathrm{C} \text { and } \mathrm{H} \text { and a decrease of ash content. }\end{array}$ \\
\hline
\end{tabular}

Fakoussa and Frost (1999)
- HA from lignite, with a $20 \%$ high molecular weight fractions and a $75 \%$ low molecular weight fractions (determined by gel permeation chromatography)

- Trametes versicolor DSM 3086

- Standing flask cultures with malt extract medium diluted to $1 / 5$ and $0.85 \mathrm{~g} / \mathrm{L} \mathrm{HA}$ in an incubator at $30^{\circ} \mathrm{C}$ and an atmosphere of 40 vol\% oxygen for 16 days.
- For HA, absorbances at $280 \mathrm{~nm}$ decreased a $5.8 \%$ after 3 days, a $63 \%$ after 6 days and a $75 \%$ after 16 days, whereas absorbances at $450 \mathrm{~nm}$ decreased a $7.8 \%$ after 3 days, a $72 \%$ ater 6 days and a $86 \%$ after 16 days. In principle, these bleachings included the effect of both adsorption and fungal degradation.

- FA production was evaluated as well. Absorbances at $280 \mathrm{~nm}$ increased a $0 \%$ at day 3, a $245 \%$ at day 6 and a $322 \%$ at day 16 , whereas absorbances at $450 \mathrm{~nm}$ increased a $0 \%$ at day 3 , a $515 \%$ at day 7 but a $415 \%$ after 16 days.

- Gel chromatography revealed that most of the conversion took place between days 2 and 6 . At the end of the experiment, low molecular weight fractions were around $98 \%$, and their modal mass had decreased when compared to that of the untreated HA.

- Lac activities were of 15 and $25 \mathrm{U} / \mathrm{L}$ at days 0 and 16 , respectively, going through a maximum of $425 \mathrm{U} / \mathrm{L}$ at day 6 .

- Biomass dry weights of 75 and $85 \mathrm{mg}$ were obtained at days 3 and 7 , respectively, but after day 11, the weights oscillated between 58 and $70 \mathrm{mg}$. 


\begin{tabular}{|c|c|c|}
\hline Autor & Fungi, medium and experimental conditions & Comments and results \\
\hline Wunderwald et al. (2000) & $\begin{array}{l}\text { - Fluorinated HA, synthesized by spontaneous } \\
\text { oxidative polymerization of 3-fluorocatechol } \\
\text { - White-rot fungus Nematoloma frowardii b19 } \\
\text { - Flasks containing } 20 \mathrm{~mL} \text { liquid }(0.25 \mathrm{~g} / \mathrm{L} \mathrm{HA} \text {, } \\
\left.5 \mathrm{~g} / \mathrm{L} \text { glucose and } 0.025 \mathrm{~g} / \mathrm{L} \mathrm{MnCl}_{2}\right) \text {, } \\
\text { inoculated with three agar plugs (diameter } 9 \\
\mathrm{~mm}) \text { of active mycelium and incubated at } 24 \\
{ }^{\circ} \mathrm{C} \text { on a rotary shaker }(140 \mathrm{rpm}) \text { in the dark } \\
\text { for } 24 \text { days. }\end{array}$ & $\begin{array}{l}\text { - Decolorizations (as reduction of absorbance at } 450 \mathrm{~nm} \text { ) and } \mathrm{MnP} \\
\text { activities were around } 10 \% \text { and } 93 \mathrm{U} / \mathrm{L} \text { at day } 4,42 \% \text { and } 155 \mathrm{U} / \mathrm{L} \text { at } \\
\text { day } 8,48 \% \text { and } 350 \mathrm{U} / \mathrm{L} \text { at day } 10,69 \% \text { and } 407 \mathrm{U} / \mathrm{L} \text { at day } 15 \text { and } \\
77 \% \text { and } 745 \mathrm{U} / \mathrm{L} \text { at day } 24 \text {. Lac activity was negligible throughout } \\
\text { the experiment and did not exceed } 36 \mathrm{U} / \mathrm{L} \text {. } \\
\text { - It is stated that there was no absorption of HA to the fungal hyphae } \\
\text { because they displayed a light color throughout the experiment. }\end{array}$ \\
\hline
\end{tabular}

\section{Table S6}

Decolorization of humic compounds by means of fungal enzymes alone.

$\begin{array}{lll}\text { Autor } & \text { Fungi, medium and experimental conditions } & \text { Comments and results }\end{array}$




\begin{tabular}{|c|c|c|}
\hline Autor & Fungi, medium and experimental conditions & Comments and results \\
\hline $\begin{array}{l}\text { Wondrack et al. } \\
\text { (1989) }\end{array}$ & $\begin{array}{l}\text { - HA from North Dakota lignite and German } \\
\text { subbituminous coal, both coals previously treated with } \\
\text { nitric acid for improving the biodegradation } \\
\text { - LiP from the white-rot fungus Phanerochaete } \\
\text { chrysosporium Burds ME-446 } \\
\text { - Capped tubes with } 1 \mathrm{~mL} \text { mixture (buffer, } 0.1 \mathrm{mmol} / \mathrm{L} \\
\mathrm{MnSO}_{4}, 0.1 \% \text { Tween } 20,200-1000 \mathrm{U} / \mathrm{L} \mathrm{LiP,} 0.45-1.0 \\
\mathrm{mmol}_{\mathrm{L}} \mathrm{H}_{2} \mathrm{O}_{2} \text { and } 30 \text { or } 300 \mathrm{mg} / \mathrm{L} \mathrm{HA} \text { solution), flushed } \\
\text { with } 100 \% \text { oxygen and incubated at } 37^{\circ} \mathrm{C} \text {. The buffer was } \\
\text { sodium tartrate }(20 \mathrm{mmol} / \mathrm{L}, \mathrm{pH} 3 \text { ) or dimethylsuccinate } \\
\text { (10 mmol/L, pH 4.5). In one experiment, veratryl alcohol } \\
\text { was added. }\end{array}$ & $\begin{array}{l}\text { - Gel permeation chromatography was the only technique used. } \\
\text { - } 300 \mathrm{mg} / \mathrm{L} \mathrm{HA} \text { from North Dakota lignite, incubated with sodium } \\
\text { tartrate buffer, } 900 \mathrm{U} / \mathrm{L} \mathrm{LiP} \text { and an unspecified concentration of } \mathrm{H}_{2} \mathrm{O}_{2} \\
\text { for } 4 \mathrm{~h} \text { generated a peak of lower area than that representing the non- } \\
\text { incubated polymer, broader and with a lower modal mass. However, } \\
\text { there was no formation of low molecular weight fragments. Incubation } \\
\text { with dimethylsuccinate buffer, } 4500 \mathrm{U} / \mathrm{L} \mathrm{LiP} \text { and } 0.6 \mathrm{mmol} / \mathrm{L} \mathrm{H}_{2} \mathrm{O}_{2} \\
\text { (added in } 0.15 \mathrm{mmol} / \mathrm{L} \text { portions at } 0,2,4 \text { and } 6 \mathrm{~h} \text { ) led to much less } \\
\text { total degradation after } 4 \text { and } 24 \mathrm{~h} \text {, but generated many new } \\
\text { components of both higher and lower molecular weight than the } \\
\text { starting material. } \\
30 \text { mg/L HA from German subbituminous coal, incubated with } 10000 \\
\mathrm{U} / \mathrm{L} \mathrm{LiP,} 0.45 \text { mmol/L } \mathrm{H}_{2} \mathrm{O}_{2} \text {, oxygen every } 15 \text { min and an unspecified } \\
\text { pH for } 1 \mathrm{~h} \text {, also generated a peak with lower area than that of the non- } \\
\text { incubated HA, but there were not new low molecular weight peaks. } \\
\text { When the HA concentration was increased to } 300 \text { mg/L, a major } \\
\text { disappearance of coal polymer takes place in } 8 \mathrm{~h} \text {. If } 2 \text { mmol/L veratryl } \\
\text { alcohol was added, there was a near total disappearance of the coal } \\
\text { polymer peak after } 8 \mathrm{~h} \text {. }\end{array}$ \\
\hline $\begin{array}{l}\text { Willmann and } \\
\text { Fakoussa (1997) }\end{array}$ & $\begin{array}{l}\text { - HA from german lignite } \\
\text { - Purified extracellular MnP of the fungal strain RBS } 1 \mathrm{k} \\
\text { - Flasks containing } 500 \mathrm{U} / \mathrm{L} \mathrm{MnP}, 0.05 \% \mathrm{HA}, 3 \mathrm{mmol} / \mathrm{L} \\
\mathrm{H}_{2} \mathrm{O}_{2} \text { and } 0.15 \mathrm{mmol} / \mathrm{LnSO}_{4} \text { under unspecified } \\
\text { conditions. }\end{array}$ & $\begin{array}{l}\text { - In the same paper, it was found that the fungus RBS } 1 \mathrm{k} \text { was able of } \\
\text { degrading the HA. } \\
\text { - However, no bleaching or molecular mass reduction of the HA took } \\
\text { place when the enzyme alone was used. Then, the authors supposed } \\
\text { that the degradative activity of the basidiomycete RBS } 1 \mathrm{k} \text { was bound } \\
\text { to the cell wall or acted only near the cell wall, and that the adsorption } \\
\text { of HA molecules onto the fungal hyphae might be required for their } \\
\text { biodegradation }\end{array}$ \\
\hline
\end{tabular}




\begin{tabular}{|c|c|c|}
\hline Autor & Fungi, medium and experimental conditions & Comments and results \\
\hline $\begin{array}{l}\text { Hofrichter and } \\
\text { Fritsche (1997a) }\end{array}$ & $\begin{array}{l}\text { - HS from german lignite. The humic fraction had a modal } \\
\text { mass around } 2.5 \mathrm{kDa} \text { and the fulvic fraction, around } 0.7 \\
\mathrm{kDa} \text {. } \\
\text { MnP from the white-rot fungus Nematoloma frowardii } \\
\text { b19. } \\
\text { - } 5 \text {-mL culture flasks containing } 10 \mathrm{~mL} \text { reaction mixture } \\
\text { on a rotary shaker }(160 \mathrm{rpm}) \text { at } 28^{\circ} \mathrm{C} \text { in the dark over a } \\
\text { period of } 168 \mathrm{~h} \text {. The reaction solution consisted of } 61 \\
\text { mmol/L sodium malonate buffer }(\mathrm{pH} 4.5), 250 \mathrm{mg} / \mathrm{L} \mathrm{HA} \text {, } \\
2.5 \mathrm{mmol} / \mathrm{L} \mathrm{MnCl}_{2}, 30.1 \mathrm{mmol} / \mathrm{L} \text { glucose, } 20 \mathrm{U} / \mathrm{L} \\
\text { glucose oxidase (from } \text { Aspergillus niger, low in catalase) } \\
\text { continously generating } \mathrm{H}_{2} \mathrm{O}_{2} \text { at the rate of } 20 \\
\text { nmol/min/ml during the course of reaction, } 0.6 \mathrm{mmol} / \mathrm{L} \\
\text { glutathione, } 783 \mathrm{mmol} / \mathrm{L} \text { dimethylformamide and } \\
\text { enzyme crude extract corresponding to } 800 \mathrm{U} / \mathrm{L} \mathrm{MnP}\end{array}$ & $\begin{array}{l}\text { - Degradation of the lignite HS by the Nematoloma frowardii b19 was } \\
\text { seen in an agarized medium by the authors (Hofrichter and Fritsche, } \\
\text { 1997b). The fungus produced Lac, LiP and MnP, but only the last one } \\
\text { was selected, because it high stability. } \\
\text { - Enzyme activity decreased to } 590 \mathrm{U} / \mathrm{L} \text { immediately after addition to } \\
\text { the liquid culture (due to inhibition because the HS) and remained } \\
\text { almost constant during the } 168 \mathrm{~h} \text {. } \\
\text { - For the humic fraction, the absorbance at } 360 \mathrm{~nm} \text { decreased a } 28 \% \\
\text { after } 10 \mathrm{~h} \text { and a } 62 \% \text { after } 168 \mathrm{~h} \text {, whereas absorbance at } 450 \mathrm{~nm} \\
\text { decreased a } 36 \% \text { at } 10 \mathrm{~h} \text { and a } 73 \% \text { at } 168 \mathrm{~h} \text {. } \\
\text { - For the fulvic fraction, absorbance at } 360 \mathrm{~nm} \text { increased a } 61 \% \text { after } 10 \\
\text { h and a } 95 \% \text { after } 168 \mathrm{~h}, \text { but at } 450 \mathrm{~nm} \text {, it increased a } 130 \% \text { after } 10 \mathrm{~h} \text {, } \\
\text { and slightly decreased from } 24 \text { to } 168 \mathrm{~h} \text {. } \\
\text { Gel permeation chromatography confirmed the changes in } \\
\text { absorbance: degradation of HA and formation of FA were most } \\
\text { effective within the first } 10 \mathrm{~h} \text { of the reaction. It also was seen that } \\
\text { repolymerization reactions took place in HA, because the apparition of } \\
\text { a peak around } 30 \mathrm{kDa} \text { at } 10 \mathrm{~h} \text {. However, the peak disappeared as the } \\
\text { reaction progressed. }\end{array}$ \\
\hline
\end{tabular}




\begin{tabular}{|c|c|c|}
\hline Autor & Fungi, medium and experimental conditions & Comments and results \\
\hline $\begin{array}{l}\text { Hofrichter et al. } \\
\text { (1998) }\end{array}$ & $\begin{array}{l}\text { - Synthetic }{ }^{14} \mathrm{C} \text {-labelled HA prepared from }{ }^{14} \mathrm{C} \text {-catechol by } \\
\text { spontaneous polymerization or by Lac-catalyzed } \\
\text { polymerization. The modal mass of the spontaneously } \\
\text { polymerized one was around } 3.5 \mathrm{kDa} \text {. } \\
\text { - } \mathrm{MnP} \text { from the white-rot fungus Nematoloma frowardii } \\
\text { b19. } \\
\text { - Sterile } 10 \text {-mL tubes tightly closed with rubber septa and } \\
\text { sealed with plastic screw caps. The tubes contained the } \\
\text { following sterilized components in a total of } 1 \mathrm{ml}: 30 \\
\text { mmol/L sodium malonate buffer (pH } 4.5), 1 \mathrm{mmol} / \mathrm{L} \\
\mathrm{MnCl}_{2}, 15 \text { mmol/L glucose, } 40 \mathrm{U} / \mathrm{L} \text { glucose oxidase } \\
\text { (from Aspergillus niger, low in catalase) to generate } \\
\mathrm{H}_{2} \mathrm{O}_{2}, 0 \text {, } 1 \text { or } 10 \mathrm{mmol} / \mathrm{L} \text { glutathione, and } 2000 \mathrm{U} / \mathrm{L} \mathrm{MnP.} \\
\mathrm{HA} \text { was added in } 0.1 \mathrm{M} \text { NaOH to a final radioactivity of } \\
1682 \mathrm{~Bq} \text {. The samples were incubated at } 37{ }^{\circ} \mathrm{C} \text { on a } \\
\text { rotary shaker ( } 160 \mathrm{rpm} \text { ) for } 144 \mathrm{~h} \text {. }\end{array}$ & $\begin{array}{l}\text { - The percentage of HA converted to }{ }^{14} \mathrm{CO}_{2} \text { increased with time, but the } \\
\text { highest amounts of carbon dioxide were released within the first } 24 \mathrm{~h} \\
\text { of incubation. After } 144 \mathrm{~h} \text {, it was of around } 16 \% \text { for } 0 \mathrm{mmol} / \mathrm{L} \\
\text { glutathione, } 43 \% \text { for } 1 \mathrm{mmol} / \mathrm{L} \text { glutathione and } 50 \% \text { for } 20 \mathrm{mmol} / \mathrm{L} \\
\text { glutathione. The polymerization of the } \mathrm{HA} \text { (spontaneous of catalyzed } \\
\text { by Lac) did not considerably influence the results. } \\
\text { - A sample of the HA generated by spontaneous polymerization and } \\
\text { treated with } 10 \mathrm{mmol} / \mathrm{L} \text { glutathione for } 144 \mathrm{~h} \text { was subjected to gel } \\
\text { permeation chromatography, and it was observed that there was } \\
\text { decrease of the modal mass from } 3.5 \mathrm{kDa} \text { to } 1.5 \mathrm{kDa} \text { and the } \\
\text { formation of low-molecular-mass products (apparition of a peak } \\
\text { below } 0.25 \mathrm{kDa} \text { ). Furthermore, the total radioactivity in the reaction } \\
\text { mixture decreased by about } 50 \%\end{array}$ \\
\hline $\begin{array}{l}\text { Ziegenhagen and } \\
\text { Hofrichter (1998) }\end{array}$ & $\begin{array}{l}\text { - HA from german lignite } \\
\text { - MnP from the white-rot fungus Clitocybula dusenii b11 } \\
\text { - } 10 \text {-mL flasks containing } 4 \mathrm{~mL} \text { of the reaction mixture on } \\
\text { a rotary shaker }(180 \mathrm{rpm}) \text { for } 24 \mathrm{~h} \text {. The mixture contained } \\
\text { sodium malonate }(50 \mathrm{mmol} / \mathrm{L}, \mathrm{pH} 4.5) \text { as basal buffer, } 5 \\
-500 \mathrm{mg} / \mathrm{L} \mathrm{HA}, 0-10 \mathrm{mmol} / \mathrm{L} \text { glutathione, } 0-5 \% \mathrm{v} / \mathrm{v} \\
N, N \text {-dimethylformamide and } 0-10 \% \text { dimethylsulfoxide. }\end{array}$ & $\begin{array}{l}\text { - The medium also contained } 1 \mathrm{mmol} / \mathrm{L} \mathrm{MnCl}_{2} \text { and } \mathrm{H}_{2} \mathrm{O}_{2} \text { continuously } \\
\text { generated by glucose oxidase of Aspergillus niger at a rate of } 0.046 \\
\text { mmol/min. The incubation temperature was of } 37^{\circ} \mathrm{C} \text {. These three } \\
\text { conditions were optimized previously for } \mathrm{MnP} \text { in media without HA. } \\
\text { - The highest decolorizations (reduction of absorbance at } 450 \mathrm{~nm} \text { ) were } \\
\text { of } 50 \% \text { for } 250 \mathrm{mg} / \mathrm{L} \mathrm{HA} \text {, of } 67 \% \text { for } 250 \mathrm{mg} / \mathrm{L} \mathrm{HA}+0.6 \mathrm{mmol} / \mathrm{L} \\
\text { glutathione and of } 71 \% \text { for } 250 \mathrm{mg} / \mathrm{L} \mathrm{HA}+0.6 \mathrm{mmol} / \mathrm{L} \text { glutathione + } \\
4 \% N, N \text {-dimethylformamide. Dimethylformamide performed better } \\
\text { than dimethylsulfoxide. } \\
\text { - Gel permeation chromatography indicated a decrease of the amount of } \\
\text { HA and of its modal mass as the incubation time increased (see Figure } \\
\text { 1a). The production of FA was also monitored, and both its } \\
\text { concentration and modal mass became higher. }\end{array}$ \\
\hline
\end{tabular}




\begin{tabular}{|c|c|c|}
\hline Autor & Fungi, medium and experimental conditions & Comments and results \\
\hline $\begin{array}{l}\text { Ralph and } \\
\text { Catcheside (1998b) }\end{array}$ & $\begin{array}{l}\text { - HA from Morwell brown coal, soluble between } \mathrm{pH} 3 \text { and } \\
4.5 \\
\text { - Commercial MnP from the white-rot fungus } \\
\text { Phanerochaete chrysosporium } \\
\text { - Dialysis tubing (membranes of } 12 \mathrm{kDa} \text { ) containing } 0.14 \\
\text { mg HA in } 1 \mathrm{~mL} \text { lactate buffer }(0.5 \mathrm{~mol} / \mathrm{L} \text { sodium lactate, } \\
\mathrm{pH} 4.5 \text { ) was suspended in an external solution of } 5 \mathrm{~mL} \\
\text { lactate buffer with } 5 \text { units partially purified } \mathrm{MnP}, 1 \\
\text { mmol/ } \mathrm{L} \mathrm{H}_{2} \mathrm{O}_{2} \text { (added at a rate of } 0.05 \mathrm{~mL} / \mathrm{h} \text { for } 6 \mathrm{~h} \text { with } \\
\text { constant stirring) and } 1 \mathrm{mmol} / \mathrm{L} \mathrm{MnSO}_{4} \text {, and incubated at } \\
30{ }^{\circ} \mathrm{C} \text { for } 24 \mathrm{~h} \text {. }\end{array}$ & $\begin{array}{l}\text { - Neither the modal apparent relative mass nor the absorbance changed } \\
\text { when } \mathrm{MnP}, \mathrm{H}_{2} \mathrm{O}_{2} \text { or } \mathrm{Mn} \text { (II) was omitted from the external solution. } \\
\text { - When all the reactants were present, the modal mass of the HA } \\
\text { increased by } 18 \% \text {, but no change was observed in the absorbance at } \\
400 \mathrm{~nm} \text {. MnP activity was not detected within dialysis tubing, } \\
\text { indicating that the membrane remained impermeable to the enzyme } \\
\text { and that the transformation was due to a small species generated in the } \\
\text { external solution. } \\
\text { Further experiments with } \mathrm{Mn}(\mathrm{III}) \text { and } \mathrm{HA} \text { in a malonate buffer under } \\
\text { air, oxygen and a mixture of } 5 \% \mathrm{H}_{2}+95 \% \mathrm{~N}_{2} \text { pointed out that this } \\
\text { species, produced by the oxidation of Mn(II) by the MnP, was the } \\
\text { responsible of the polymerization of } \mathrm{HA} \text { under certain atmospheres } \\
\text { (air and } \mathrm{H}_{2}+\mathrm{N}_{2} \text { ), but that it also could depolymerize } \mathrm{HA} \text { under other } \\
\text { ones (oxygen) }\end{array}$ \\
\hline
\end{tabular}




\begin{tabular}{|c|c|c|}
\hline Autor & Fungi, medium and experimental conditions & Comments and results \\
\hline $\begin{array}{l}\text { Ralph and } \\
\text { Catcheside (1999) }\end{array}$ & $\begin{array}{l}\text { Two HAs from Morwell brown coal: the first one was } \\
\text { soluble between } \mathrm{pH} 3 \text { and } 4.5 \text {, and the second one, } \\
\text { soluble below } \mathrm{pH} 6 \text {. The first one was ultrafiltered } \\
\text { through a } 30-\mathrm{kDa} \text { membrane and the second one, } \\
\text { methylated and ultrafiltered through a } 10-\mathrm{kDa} \text { membrane. } \\
\text { - LiP from the white-rot fungus Phanerochaete } \\
\text { chrysosporium } \\
\text { - Into } 100 \text {-mL conical flasks, containing } 20 \mathrm{~mL} \text { buffer ( } 10 \\
\text { mmol/L sodium tartrate, } \mathrm{pH} 4.5 \text { ) with } 0.2 \mathrm{mg} \mathrm{HA} \text { (and } \\
\text { sometimes, } \mathrm{NaVO}_{3} \text { ), two separate solutions were added } \\
\text { dropwise and concurrently over } 4 \mathrm{~h} \text { : } 5 \mathrm{~mL} \text { buffer } \\
\text { containing } 30 \mu \mathrm{mol}_{2} \mathrm{H}_{2} \text { and } 5 \mathrm{~mL} \text { buffer containing } \\
14.9 \mu \text { mol veratryl alcohol and } 8.6 \text { units LiP. The flasks } \\
\text { were stirred in darkness at } 25^{\circ} \mathrm{C} \text { during this } 4 \text {-h period } \\
\text { and for a further } 20 \mathrm{~h} \text {. Some flasks were subjected to } \\
\text { oxygen sparging. }\end{array}$ & 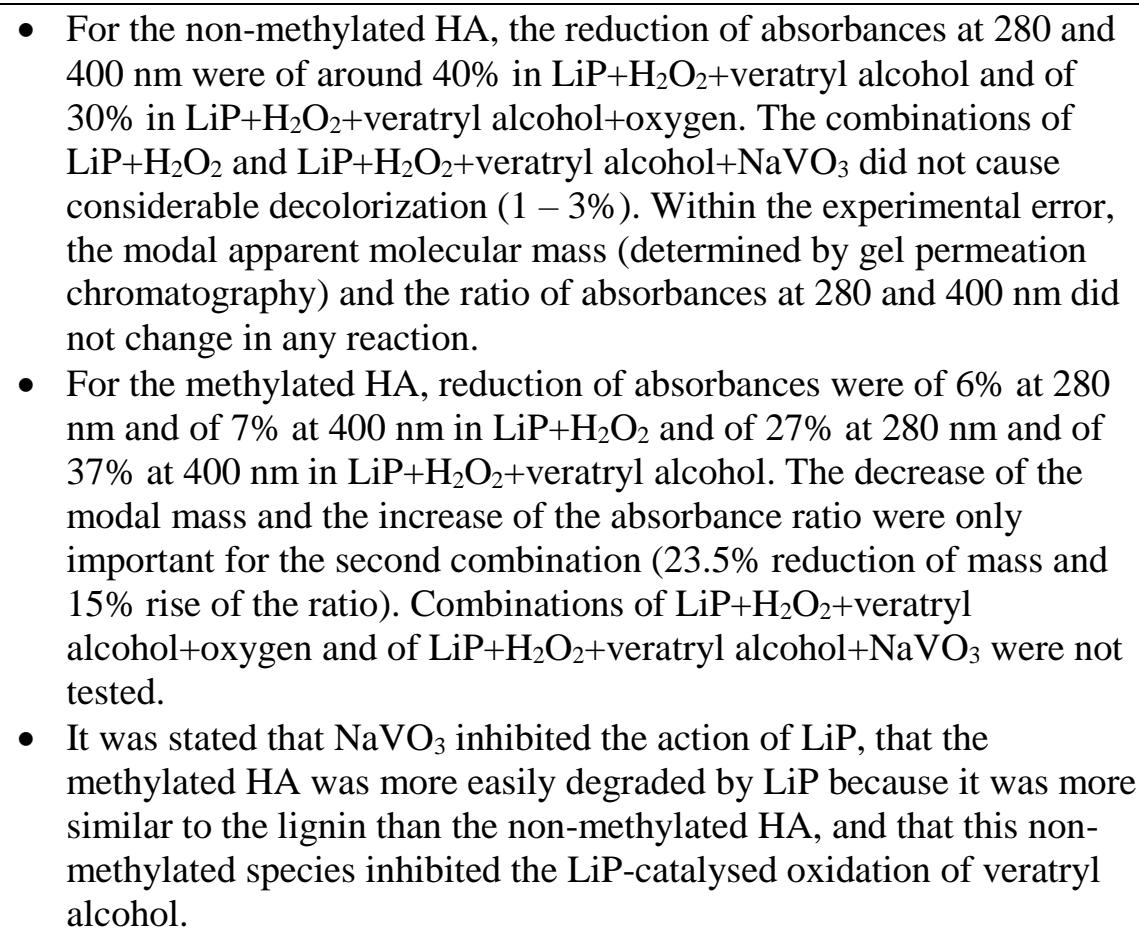 \\
\hline
\end{tabular}




\begin{tabular}{|c|c|c|}
\hline Autor & Fungi, medium and experimental conditions & Comments and results \\
\hline $\begin{array}{l}\text { Claus and Filip } \\
\text { (1998) }\end{array}$ & $\begin{array}{l}\text { - HA from groundwater (Fuhrberg, Germany), HA and FA } \\
\text { from bog lake (Hohlohsee, Germany) and HS from the } \\
\text { Saint Mary's River (Georgia, USA) } \\
\text { - Lac from Polyporus versicolor strain DSM } 3086 \\
\text { - } 0.9 \mathrm{~mL} \text { of a solution containing } 0.5 \mathrm{~g} / \mathrm{L} \text { lake HA in } 100 \\
\text { mmol/L phosphate buffer (pH 5.9) were mixed with } 0.1 \\
\mathrm{~mL} \text { of a Lac preparation }(12 \mu \mathrm{g} / \mathrm{mL} \text { protein and } 2500 \\
\text { nkat/mg specific activity). The effect of adding } 0-4 \\
\text { mmol/L of } 1 \text {-hydroxybenzotriazole (a redox mediator) } \\
\text { was tested. The mixture was incubated for } 7 \text { days at } 30^{\circ} \mathrm{C} \\
\text { When determined the optimum concentration of redox } \\
\text { mediator, the experiment was repeated with FA from lake } \\
\text { water, HS from river and HA from groundwater }\end{array}$ & $\begin{array}{l}\text { - The initial idea was to use Lac from } C \text {. cladosporioides } \mathrm{P} 8 \text {, but } \\
\text { preliminary tests revealed that its enzymatic activity in media } \\
\text { containing HA was lower than that of the Lac from } P \text {. versicolor. } \\
\text { Furthermore, the activities of both enzymes were functions of the HA } \\
\text { concentration and its origin. } \\
\text { - Decolorization of HA from bog lake (determined through the } \\
\text { absorvance at } 465 \mathrm{~nm} \text { ) reached a maximum of } 50.5 \% \text { at } 2 \mathrm{mmol} / \mathrm{L} \\
\text { redox mediator. } \\
\text { Decolorizations for FA from lake water, HS from river and HA from } \\
\text { groundwater in liquid media containing } 2 \text { mmol/L redox mediator } \\
\text { were of } 39,37 \text { and } 45 \% \text {, respectively. The ratios of absorbances at } \\
465 \text { nm and } 665 \text { nm increased a } 222 \% \text { for lake FA, a } 123 \% \text { for river } \\
\text { HS and a } 167.5 \% \text { for groundwater HA. }\end{array}$ \\
\hline Gramss et al. (1999) & $\begin{array}{l}\text { - HS from a black calcareous forest mull } \\
\text { - Five oxidoreductase enzymes (catalase from bobine liver, } \\
\text { glucose oxidase from Aspergillus niger, Lac from } \\
\text { Pyricularia oryzae, horseradish peroxidase coupled with } \\
\mathrm{H}_{2} \mathrm{O}_{2} \text { and tyrosinase from Agaricus bisporius), one } \\
\text { hydrolase ( } \beta \text {-glucosidase from almonds) and two abiotic } \\
\text { oxidants (hydrogen peroxide and manganese triacetate). } \\
\text { - Serum bottles containing } 4 \mathrm{~mL} \text { of sterilized HS solutions } \\
\text { ( } 1 \mathrm{~g} / \mathrm{L} \mathrm{HS} \text { in } 0.1 \text { mol/L citrate-phosphate buffer) } \\
\text { amended with } 1 \mathrm{~mL} \text { enzyme/oxidant solution. Incubation } \\
\text { at } 24^{\circ} \mathrm{C} \text { for } 24 \mathrm{~h} \text {. }\end{array}$ & $\begin{array}{l}\text { - Concentrations of the enzymes and oxidants were: catalase }(1.4 \mathrm{~g} / \mathrm{L}) \text {, } \\
\text { glucose oxidase }(1.2 \mathrm{~g} / \mathrm{L}), \mathrm{Lac}(2.0 \mathrm{~g} / \mathrm{L}) \text {, peroxidase }(0.22 \mathrm{~g} / \mathrm{L} \text { coupled } \\
\left.\text { with } 1 \mathrm{~g} / \mathrm{L} \mathrm{H}_{2} \mathrm{O}_{2}\right), \text { tyrosinase }(2.2 \mathrm{~g} / \mathrm{L}), \beta \text {-glucosidase }(1.2 \mathrm{~g} / \mathrm{L}) \text {, } \\
\text { hydrogen peroxide }(1.0 \mathrm{~g} / \mathrm{L}) \text { and manganese triacetate }(0.5 \mathrm{~g} / \mathrm{L}) \text {. } \\
\text { - Tyrosinase (a MMO) and catalase did not reduce the absorbance of } \\
\text { HS solutions at } 340 \mathrm{~nm} \text {. Glucose oxidase and Lac only gave } \\
\text { decolorations of } 2.9 \% \text { and } 3.4 \% \text {, respectively. } \beta \text {-glucosidase caused a } \\
\text { fall of } 21.5 \% \text { in the absorbance, but a } 19.5 \% \text { was due to precipitation } \\
\text { by formation of enzyme-HS complexes. } \\
\text { - Hydrogen peroxide, manganese triacetate (representative of } \mathrm{MnP}) \text { and } \\
\text { plant peroxidase achived decolorizations of } 9.3,13.9 \text { and } 18.3 \% \text {, } \\
\text { respectively. }\end{array}$ \\
\hline
\end{tabular}




\begin{tabular}{|c|c|c|}
\hline Autor & Fungi, medium and experimental conditions & Comments and results \\
\hline $\begin{array}{l}\text { Wunderwald et al. } \\
\text { (2000) }\end{array}$ & $\begin{array}{l}\text { - Fluorinated } \mathrm{HA} \text {, synthesized by spontaneous oxidative } \\
\text { polymerization of } 3 \text {-fluorocatechol. It contained } 50.4 \% \\
\mathrm{C}, 2.6 \% \mathrm{H}, 13.6 \% \mathrm{~F} \text { and } 33.4 \% \mathrm{O} \text {. } \\
\text { - } \mathrm{MnP} \text { from the white-rot fungus Nematoloma frowardii } \\
\text { b19 } \\
100-\mathrm{mL} \text { flasks containing } 20 \mathrm{~mL} \text { of the reaction mixture } \\
(50 \mathrm{mmol} / \mathrm{L} \text { sodium malonate buffer, } \mathrm{pH} 4.5,1 \mathrm{mmol} / \mathrm{L} \\
\mathrm{MnCl}_{2}, 0.6 \mathrm{mmol} / \mathrm{L} \text { glutathione, } 100 \mathrm{mg} / \mathrm{L} \mathrm{HA}, 500 \mathrm{U} / \mathrm{L} \\
\mathrm{MnP} \text { and } \mathrm{H}_{2} \mathrm{O}_{2} \text { continuously generated by } \\
\text { glucose/glucose oxidase from Aspergillus } \\
\text { - niger), incubated at } 37{ }^{\circ} \mathrm{C} \text { in the dark and stirred } \\
\text { continuously for } 75 \mathrm{~h}\end{array}$ & $\begin{array}{l}\text { - In the same paper, it was found that the fungus Nematoloma frowardii } \\
\text { b19 degraded the HA, and that its main excreted enzyme was MnP. } \\
\text { - MnP was able of degrading the HA, because the unbounded fluorine } \\
\text { in the medium was } 0.01 \mathrm{mmol} / \mathrm{L} \mathrm{F}_{2} \text { at the beginning of the reaction, } \\
\text { quickly rose to around } 0.18 \mathrm{mmol} / \mathrm{L} \mathrm{F}_{2} \text { after } 5 \mathrm{~h} \text {, and then, increased } \\
\text { slowly to } 0.325 \mathrm{mmol} / \mathrm{L} \mathrm{F}_{2} \text { after } 75 \mathrm{~h} \text {. } \\
\text { - Gel permeation chromatography indicated that during the first } 5 \mathrm{~h} \\
\text { incubation, about } 80 \% \text { of the HA was converted, but that the modal } \\
\text { molecular mass of the residual HA was not changed. FA production } \\
\text { was investigated as well: this fraction increased simultaneously with } \\
\text { the HA conversion and its modal mass slightly rose. After } 75 \mathrm{~h} \text { the } \\
100 \% \text { of the HA had been degraded. }\end{array}$ \\
\hline $\begin{array}{l}\text { Zavarzina et al. } \\
(2004)\end{array}$ & $\begin{array}{l}\text { - HA from peat, soddy-podzolic soil and chernozem } \\
\text { - Lac of the white-rot basidiomycete Panus tigrinus } 8 / 18 \\
\text { - Incubation mixtures contained } 0.4 \mathrm{~mL} \mathrm{HA}(2 \mathrm{mg}) \text { and } \\
0.02 \mathrm{~mL} \mathrm{Lac} \text { preparation }(0.48 \mathrm{mg} / \mathrm{mL}) \text { in } 1 \mathrm{~mL} \text { buffer } \\
(20 \mathrm{mmol} / \mathrm{L} \text { sodium-acetate buffer, } \mathrm{pH} 5.0) \text { at } 30^{\circ} \mathrm{C} \text { for } \\
96 \mathrm{~h}\end{array}$ & $\begin{array}{l}\text { - Absorbances at } 280 \mathrm{~nm} \text { decreased a } 26.9 \% \text { for peat HA and a } 13 \% \text { for } \\
\text { soddy-podzolic HA, but increased a } 11 \% \text { for chermozen HA. The ratio } \\
\text { of absorbances at } 465 \mathrm{~nm} \text { and at } 650 \mathrm{~nm} \text { always decreased: a } 12 \% \text { for } \\
\text { peat HA, a } 5 \% \text { for soddy-podzolic HA and a } 11 \% \text { for chernozem HA. } \\
\text { - Gel chromatography showed that the HA from chernozem was } \\
\text { degradated (the relative content of its low molecular weight fraction } \\
\text { increased, apparently in expense of high molecular weight fraction), } \\
\text { whereas the HA from peat suffered polymerization (the content of its } \\
\text { high molecular weight fraction increased as well as the average } \\
\text { molecular weight of the low molecular weight fraction). For the HA } \\
\text { from soddy-podzolic soil, the result was intermediate: the content of } \\
\text { high molecular weight fraction decreased, but the average molecular } \\
\text { weight of low molecular weight fraction increased } \\
\text { Further experiments on inhibition of Lac by HA probed that this } \\
\text { existed, that it was of the competitive type and increased with } \\
\text { increasing HA concentration. }\end{array}$ \\
\hline
\end{tabular}




\begin{tabular}{|c|c|c|}
\hline Autor & Fungi, medium and experimental conditions & Comments and results \\
\hline $\begin{array}{l}\text { Zahmetkesh et al. } \\
\text { (2016) }\end{array}$ & $\begin{array}{l}\text { - Coal HA, containing a } 3 \% \text { small molecules }(<0.5 \mathrm{kDa}) \text {, a } \\
27 \% \text { medium-sized compounds }(0.5-1 \mathrm{kDa}) \text { and a } 70 \% \\
\text { large substances }(1-6.5 \mathrm{kDa}) \text {. } \\
\text { - Lac from Trametes versicolor. } \\
\text { - } 150 \text {-mL flasks containing } 50 \mathrm{~mL} \text { of Lac solution at } 500 \\
\mathrm{U} / \mathrm{L} \text { in malonate buffer }(\mathrm{pH} 4.5) \text { and } 2 \mathrm{~mL} \mathrm{HA} \text { solution } \\
\text { (for a final concentration around } 308 \mathrm{mg} / \mathrm{L}) \text {, incubated at } \\
26^{\circ} \mathrm{C} \text { and } 130 \mathrm{rpm} \text { for } 24 \mathrm{~h} \text {. Occasionally, } 1 \mathrm{mmol} / \mathrm{L} \text { of } \\
\text { Lac mediator was added. }\end{array}$ & $\begin{array}{l}\text { - Lac mediators were 1-hydroxy-benzotriazol hydrate, 2,2'-azino-bis- } \\
\text { (3-ethylbenz-thiazoline-6-sulfonic acid) and violuric acid. Size } \\
\text { exclusion chromatography was the only analytical technique used. } \\
\text { - Reduction of chromatographic area was of } 20.6 \% \text { for Lac alone, of } \\
\text { 64\% for Lac with 2,2'-azino-bis-(3-ethylbenz-thiazoline-6-sulfonic } \\
\text { acid), of 32\% for Lac with 1-hydroxy-benzotriazol hydrate and of } \\
19.8 \% \text { for Lac with violuric acid. } \\
\text { - Proportions of } 4 \% \text { small, } 7 \% \text { medium and } 89 \% \text { large molecules for } \\
\text { Lac alone, of } 2 \% \text { small, } 8 \% \text { medium and } 90 \% \text { large compounds for } \\
\text { Lac plus } 2,2 \text {-azino-bis-(3-ethylbenz-thiazoline-6-sulfonic acid), of } \\
\text { 2\% small, 32\% medium and } 66 \% \text { large substances for Lac plus } 1 \text { - } \\
\text { hydroxy-benzotriazol and of } 2 \%, 44 \% \text { medium and } 54 \% \text { large } \\
\text { molecules for Lac plus violuric acid were found. }\end{array}$ \\
\hline
\end{tabular}

Media where the reactions took place are described in these tables, except those of Kirk et al. (1978) and of Tien and Kirk (1988), in order to avoid an excesive size of the rows. They are as follows: for Kirk et al. (1978), the basal medium contained $0.2 \mathrm{~g} / \mathrm{L} \mathrm{KH} \mathrm{PO}_{4}, 0.05 \mathrm{~g} / \mathrm{L}$

$\mathrm{MgSO}_{4} \cdot 7 \mathrm{H}_{2} \mathrm{O}, 0.01 \mathrm{~g} / \mathrm{L} \mathrm{CaCl}_{2}, 1 \mathrm{~mL}$ mineral solution and $0.5 \mathrm{~mL}$ vitamin solution. This mineral solution consisted of $1.5 \mathrm{~g} / \mathrm{L}$ nitrilotriacetate, 3 $\mathrm{g} / \mathrm{L} \mathrm{MgSO}{ }_{4} \cdot 7 \mathrm{H}_{2} \mathrm{O}, 0.5 \mathrm{~g} / \mathrm{L} \mathrm{MnSO}_{4} \cdot \mathrm{H}_{2} \mathrm{O}, 1.0 \mathrm{~g} / \mathrm{L} \mathrm{NaCl}, 100 \mathrm{mg} / \mathrm{L} \mathrm{FeSO}_{4} \cdot 7 \mathrm{H}_{2} \mathrm{O}, 100 \mathrm{mg} / \mathrm{L} \mathrm{CoSO} 4,82 \mathrm{mg} / \mathrm{L} \mathrm{CaCl}, 100 \mathrm{mg} / \mathrm{L} \mathrm{ZnSO} 4,10 \mathrm{mg} / \mathrm{L}$ $\mathrm{CuSO}_{4} \cdot 5 \mathrm{H}_{2} \mathrm{O}, 10 \mathrm{mg} / \mathrm{L} \mathrm{AlK}\left(\mathrm{SO}_{4}\right)_{2}, 10 \mathrm{mg} / \mathrm{L} \mathrm{H}_{3} \mathrm{BO}_{3}, 10 \mathrm{mg} / \mathrm{L} \mathrm{NaMoO}$, whereas the vitamin solution consisted of $2 \mathrm{mg} / \mathrm{L}$ biotin, $2 \mathrm{mg} / \mathrm{L}$ folic acid, $5 \mathrm{mg} / \mathrm{L}$ thiamine $\cdot \mathrm{HCl}, 5 \mathrm{mg} / \mathrm{L}$ riboflavin, $10 \mathrm{mg} / \mathrm{L}$ pyridoxine $\cdot \mathrm{HC} 1,0.1 \mathrm{mg} / \mathrm{L}$ cyanocobalamine, $5 \mathrm{mg} / \mathrm{L}$ nicotinic acid, $5 \mathrm{mg} / \mathrm{L}$ DL-calcium pantothenate, $5 \mathrm{mg} / \mathrm{L} p$-aminobenzoic acid and $5 \mathrm{mg} / \mathrm{L}$ thioctic acid. For Tien and Kirk (1988), the medium contained $1.68 \%$ glucose, 16.8 mmol/L 2,2-dimethylsuccinate ( $\mathrm{pH} 4.2), 1.68 \mathrm{mg} / \mathrm{L}$ thiamin, $0.336 \mathrm{~g} / \mathrm{L}$ ammonium tartrate, $0.67 \%$ veratryl alcohol, $100 \mathrm{~mL}$ spore suspension, $100 \mathrm{~mL}$ basal medium and $60 \mathrm{~mL}$ trace element solution. This basal medium consisted of $20 \mathrm{~g} / \mathrm{L} \mathrm{KH}_{2} \mathrm{PO}_{4}, 5 \mathrm{~g} / \mathrm{L} \mathrm{MgSO} 4$ and $1 \mathrm{~g} / \mathrm{L} \mathrm{CaCl} 2$ and $100 \mathrm{~mL}$ trace elements solution, whereas the components of the trace element solutin were $3 \mathrm{~g} / \mathrm{L} \mathrm{MgSO} 4,0.5 \mathrm{~g} / \mathrm{LMnSO} 4,1.0 \mathrm{~g} / \mathrm{LNaCl}, 0.1 \mathrm{~g} / \mathrm{L}$ 
$\mathrm{FeSO}_{4} \cdot 7 \mathrm{H}_{2} \mathrm{O}, 0.1 \mathrm{~g} / \mathrm{L} \mathrm{COCl}_{2}, 0.1 \mathrm{~g} / \mathrm{L} \mathrm{ZnSO} \cdot 7 \mathrm{H}_{2} \mathrm{O}, 0.1 \mathrm{~g} / \mathrm{L} \mathrm{CuSO} 4,10 \mathrm{mg} / \mathrm{L} \mathrm{AlK}\left(\mathrm{SO}_{4}\right)_{2} \cdot 12 \mathrm{H}_{2} \mathrm{O}, 10 \mathrm{mg} / \mathrm{L} \mathrm{H}_{3} \mathrm{BO}_{3}, 10 \mathrm{mg} / \mathrm{L} \mathrm{Na}_{2} \mathrm{MoO}_{4} \cdot 2 \mathrm{H}_{2} \mathrm{O}$ and $1.5 \mathrm{~g} / \mathrm{L}$ nitrilotriacetate.

Kirk, T.K., Schultz, E., Connors, W.J., Lorenz, L.F., Zeikus, J.G., 1978. Influence of culture parameters on lignin metabolism by Phanerochaete chrysosporium. Arch. Microbiol. 117(3), 277-285.

Tien, M., Kirk, T.K., 1988. Lignin peroxidase of Phanerochaete chrysosporium. in: Methods Enzymol., Vol. 161, Academic Press, pp. $238-249$. 